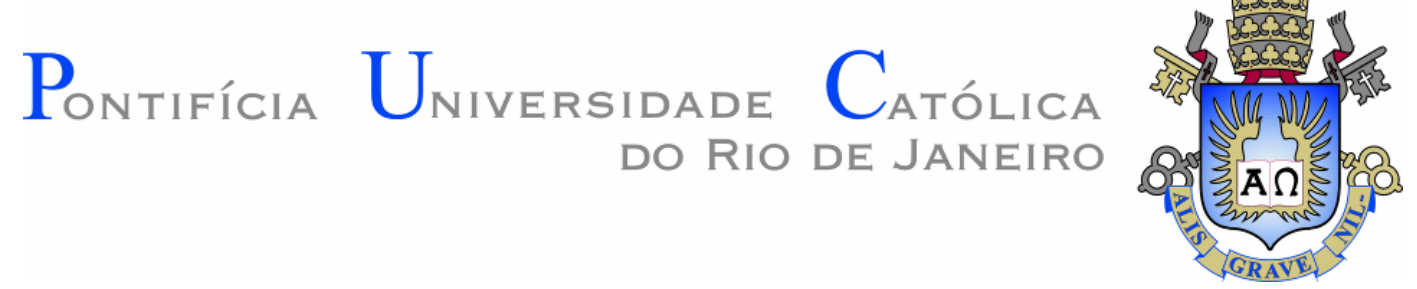

Thais Gulias Oliveira

\title{
Análise da fragmentação florestal e a Lei de Proteção da Vegetação Nativa: o município de Silva Jardim, RJ.
}

Dissertação de Mestrado

Dissertação apresentada como requisito parcial para obtenção do grau de Mestre em Geografia e Meio Ambiente e pelo Programa de Pós-Graduação em Geografia e Meio Ambiente da PUC-Rio.

Orientador: Prof. Luiz Felipe Guanaes Rego 
Pontifícia Universidade $C_{\text {atólica }}$

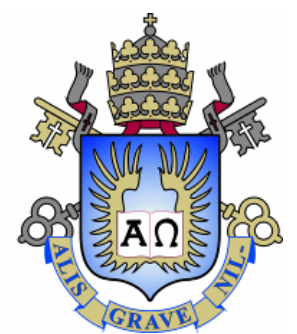

Thais Gulias Oliveira

\section{Análise da fragmentação florestal e a Lei de Proteção da Vegetação Nativa: o município de Silva Jardim, RJ.}

Dissertação apresentada como requisito parcial para obtenção do grau de mestre pelo Programa de Pósgraduação em Geografia da PUC-Rio. Submetida à avaliação da comissão examinadora abaixo.

Prof. Luiz Felipe Guanaes Rego

Orientador

Departamento de Geografia e Meio Ambiente- PUC-Rio

Prof. Rodrigo Penna Firme Pedrosa

Departamento de Geografia e Meio Ambiente - PUC-Rio

Dra. Brenda da Rocha Alexandre

Instituto Geociências- UFF

Rio de Janeiro, 28 de abril de 2020 
Todos os direitos reservados. É proibida a reprodução total ou parcial do trabalho sem autorização da universidade, da autora e do orientador.

\section{Thais Gulias Oliveira}

Graduou - se em Geografia na Universidade do Estado do Rio de Janeiro (UERJ), 2018. Desenvolvendo sua monografia de conclusão do curso sobre a aplicação de geotecnologias aliada a geografia da saúde para mapeamento de vetores, para o controle de epidemias. Iniciou o mestrado, na linha de Ecologia da Paisagem, no ano de 2018. Desenvolve projetos e pesquisas na área de aplicação de geotecnologias nas bases da ecologia da paisagem no Estado do Rio de Janeiro desde 2014.

Ficha Catalográfica

Oliveira, Thais Gulias

Análise da fragmentação florestal e a Lei de Proteção da Vegetação Nativa : o município de Silva Jardim, RJ / Thais Gulias Oliveira ; orientador: Luiz Felipe Guanaes Rego. - 2020.

104 f. : il. color. ; $30 \mathrm{~cm}$

Dissertação (mestrado)-Pontifícia Universidade Católica do Rio de Janeiro, Departamento de Geografia e Meio Ambiente, 2020.

Inclui bibliografia

1. Geografia e Meio Ambiente - Teses. 2. Ecologia da paisagem. 3. Mata Atlântica. 4. Fragmentos. 5. Lei de Proteção da Vegetação Nativa. 6. Geotecnologia. I. Rego, Luiz Felipe Guanaes. II. Pontifícia Universidade Católica do Rio de Janeiro. Departamento de Geografia e Meio Ambiente. III. Título.

CDD: 910 


\section{Agradecimentos}

Agradeço primeiramente a minha família que sempre incentivaram meus estudos e formação intelectual; ao meu pai (José Antônio), a minha mãe (Beth), a minha irmã (Thainá) e a minha avó (Esmeralda), que mesmo longe, sempre estiveram torcendo por minha jornada e pela superação dos percalços que se colocaram em meu caminho. Amo vocês. Vocês me inspiram!

Agradeço também a minha cadela (Zelda), que sempre me fez companhia nas tardes de solidão diante do individualismo ao computador. E me obrigava a sair para esvaziar a mente ao final do dia.

Agradeço imensamente aos professores da PUC-Rio por me guiarem em meus projetos e em minhas elucubrações, especialmente ao meu orientador Felipe Guanaes por acreditar nas minhas ideias.

Agradeço, especialmente, a minha banca avaliadora Brenda Alexandre, Rodrigo Penna e o Rodrigo Lobato, foram guias fundamentais no desenvolvimento dessa dissertação. Onde me via por vezes agarrada aos áudios da defesa para continuar. A Luiza Rosa Mendes, professora de inglês e amiga, que colaborou com o resumo em inglês dessa dissertação. E ao laboratório de GIS da UFC pelas orientações e ajuda.

A todos os amigos e colegas que de uma forma direta ou indireta, contribuíram, ou auxiliaram na elaboração do presente estudo, pela paciência, atenção e força que prestaram em momentos menos fáceis. Para não correr o risco de não enumerar algum não vou identificar ninguém, aqueles a quem este agradecimento se dirige sabê-lo-ão, desde já os meus agradecimentos.

Agradeço, a minha psicóloga Priscila, e todos da ONG Bia Dote, que não me deixaram sucumbir as crises de ansiedade ou devaneios de desistência.

E agradeço de todo meu coração ao meu companheiro de vida, Brendo, pela sua paciência, compreensão e ajuda prestada durante a elaboração da presente dissertação, especialmente por apresentar sempre um colo, sorriso e palavra de apoio quando sacrificava meus dias, em prol da realização deste estudo. Você foi fundamental!

O presente trabalho foi realizado com apoio da Coordenação de Aperfeiçoamento de Pessoal de Nível Superior- Brasil (CAPES)- Código de Financiamento 001. 


\section{Resumo}

Oliveira, Thais Gulias; Rego, Luiz Felipe Guanaes. análise da fragmentação florestal e a Lei de Proteção da Vegetação Nativa: o município de Silva Jardim, RJ. Rio de Janeiro, 2020. 104p. Dissertação de Mestrado Departamento de Geografia, Pontifícia Universidade Católica do Rio de Janeiro.

O município de Silva Jardim cuja região possui uma rica biodiversidade tanto em flora, quanto fauna, em seu bioma fragmentado. Um dos aliados para o processo de conservação dos biomas são as leis implementadas pelo Lei de Proteção da Vegetação Nativa, pois, visa proteger principalmente as áreas mais frágeis e de extrema importância para a recuperação da paisagem. Nesse sentido essa dissertação teve por objetivo avaliar o potencial de conservação a partir da integração da análise dos fragmentos florestais e da Lei de Proteção da Vegetação Nativa- LPVN. Para isso, a metodologia se debruçou em levantado todo o processo histórico de ocupação do município. Espacializar a LPVN através de técnicas de geoprocessamento em ambiente SIG. Utilizando os princípios da ecologia da paisagem, se escolheu as métricas de paisagem para avaliação dos fragmentos no software V-Late, podendo assim caracterizar o cenário atual. Tivemos como resultado 33,2\% do total de Silva Jardim protegidos pela LPVN. Os fragmentos muito pequenos e grandes foram os que mais chamaram atenção na análise final, tendo $45 \%$ de suas áreas protegidas, devido a sua distribuição pela paisagem. Finalmente, quando analisamos a eficiência da LPNV, não podemos anular o processo de ocupação, dado que as áreas mais fragmentadas estão nos limites de APP de curso d'água em áreas planas. Sendo assim, é preciso pensar em planos de educação e conscientização da população para a conservação da Mata Atlântica.

\section{Palavras- chave}

Ecologia da Paisagem; Mata Atlântica; Fragmentos; Lei de Proteção da Vegetação Nativa; Geotecnologia. 


\section{Abstract}

Oliveira, Thais Gulias; Rego, Luiz Felipe Guanaes. (Advisor). Analysis of forest fragments and the Native Vegetation Protection Law: the municipality of Silva Jardim, RJ. Rio de Janeiro, 2020. 104p. Dissertação de Mestrado - Departamento de Geografia, Pontifícia Universidade Católica do Rio de Janeiro.

The municipality of Silva Jardim, whose region has a rich biodiversity in both flora and fauna, in its fragmented biome. One of the allies for the conservation process of the biomes are the laws implemented by the Native Vegetation Protection Law because it aims to protect mainly the most fragile areas and of extreme importance for the recovery of the landscape. In this sense, this dissertation aimed to evaluate the conservation potential based on the integration of forest fragment analysis and the Native Vegetation Protection Law (Law 12.651 / 12). For that, the methodology looked at the entire historical occupation process of the county. Specialize Native Vegetation Protection Law through geoprocessing techniques in a GIS environment. Using the principles of landscape ecology, were chosen the landscape metrics to assess fragments in the V-Late software, thus being able to characterize the current scenery. As a result, 33.2\% of Silva Jardim's total was protected by the Native Vegetation Protection Law. The very small and large fragments were the ones that attracted the most attention in the final analysis, with $45 \%$ of their areas protected, due to their distribution across the landscape. Finally, when we analyze the efficiency of Native Vegetation Protection Law, we cannot cancel the occupation process, given that the most fragmented areas are within the limits of permanent preservation watercourse sector in flat territories. Therefore, it is necessary to think about education and awareness plans for the conservation of the Atlantic Forest.

\section{Keywords}

Landscape Ecology; Atlantic Forest, Fragments; Law of Protection of Native Vegetation; Geotechnology. 
"É preciso tentar não sucumbir sob o peso de nossas angústias, e continuar a lutar."

J.K. Rowling, Harry Potter e o Enigma do Príncipe 


\section{Sumário}

1 Introdução 13

2 Revisão conceitual $\quad 19$

2.1 Da paisagem a Ecologia da Paisagem 19

2.2 Mata Atlântica 22

$\begin{array}{ll}\text { 2.2.1 Fragmentos Florestais } & 25\end{array}$

2.3 A origem do Código Florestal a Lei de Proteção da Vegetação Nativa

2.4 Geoprocessamento 30

2.5 Métricas de paisagem como indicadores 32

3 Identificação de análise dos processos históricos da fragmentação de Silva Jardim, RJ 37

3.1 Um Breve Histórico De Silva Jardim 39

3.2 Caracterização ambiental $\quad 43$

4 Materiais e métodos $\quad 49$

$\begin{array}{ll}4.1 \text { Materiais } & 49\end{array}$

$\begin{array}{ll}\text { 4.1.1 Dados } & 49\end{array}$

4.1.2 Softwares utilizados $\quad 50$

4.2 Metodologia $\quad 51$

4.2 .1 Espacialização da Lei de Proteção da Vegetação Nativa 51

4.2.2 Aplicação das métricas de paisagem 53

4.2.3 Matriz de correlação $\quad 54$

5 Resultados e discussão $\quad 58$

5.1 Processo de Fragmentação na Bacia do Rio São João em Silva Jardim 
5.1.1 Problemas enfrentados gestão municipal integrada para conservação ambiental da Bacia do Rio São João

5.2 Espacialização da Lei de Proteção da Vegetação Nativa

5.3 Métricas de paisagem 73

5.3.1 Segmentação da Paisagem por tamanho dos Fragmentos $\quad 74$

5.3.2 Métricas de Área, densidade e tamanho 75

5.3.3 Índices de Borda 79

5.3.4 Índice de Forma $\quad 80$

5.3.5 Índice de proximidade 81

5.3.6 Índice de Área Núcleo 82

5.3.7 Área das Classes vs. Área protegida pela LPVN 83

5.4 Matriz de correlação 84

5.5 Considerações Finais 86

6 Conclusão $\quad 91$

$\begin{array}{ll}\text { Referências bibliográficas } & 94\end{array}$ 


\section{Lista de figuras}

Figura 1. Localização da Bacia do Rio São João, RJ. 15

Figura 2. Localização da Mata Atlântica. 22

Figura 3. Interface do V-Late com as métricas de paisagem. 33

Figura 4. Delimitação de Silva Jardim dentro da Bacia do Rio São João,

RJ. $\quad 37$

Figura 5. Localização de Silva Jardim, na Bacia do Rio Sâo João. 38

Figura 6. Carvalho, J. C. Mapa de la Província de Rio de Janeiro. Gravura colorida com a legenda" Mapa de la Provincia de Rio de Janeiro hecho por ordem del Presidente de la exmo. Sr. Don Antonio da Rocha Fernandes Leão para el servicio de la inmigracion". 53 × 74

Figura 7. A inauguração da estação de Capivary foi reportada e descrita pelo jornal.

Figura 8. Mapa de cobertura e uso da Bacia do Rio São João, RJ. $\quad 46$

Figura 9. Código utilizado para gerar a matriz. 54

Figura 10. Tabela aberta no RStudio com os dados gerados no V-Late e na espacialização do LPVN.

Figura 11. Matriz de correlação gerada no RStudio em ordem numérica. 56

Figura 12 Fluxograma da metodologia a ser aplicada.

Figura 13. Fragmentos Florestais de Mata Atlântica na Bacia do Rio São João, Silva Jardim- RJ. Fonte: Autora

Figura 14 Estruturar a administração da APA conforme o organograma a ser estabelecido no Regime interno intermunicipais. 63

Figura 15. Espacialização das Reservas Legais em Silva Jardim, RJ. 68 Figura 16. Espacialização das leis da LPVN em uma propriedade rural. 69 Figura 17. Espacialização das APP's de Hidrologia no município de Silva Jardim, RJ.

Figura 18. Espacialização as APP's de Relevo no município de Silva Jardim, RJ.

Figura 19. Espacialização dos fragmentos por tamanho em Silva Jardim,

RJ.

Figura 20. Gráfico de Área do Fragmento vs Número de Fragmentos. 75

Figura 21. Gráfico da Área das Classes. $\quad 76$

Figura 22. Gráfico de Número de Fragmentos. 76

Figura 23. Gráfico de Porcentagem da Paisagem.

Figura 24. Gráfico Número de Fragmentos vs Tamanho Médio dos fragmentos.

Figura 25. Gráfico de Tamanho Médio do Fragmento e Desvio Padrão. 78

Figura 26. Gráfico de Total de Borda. $\quad 79$

Figura 27. Gráfico de Densidade de Borda. $\quad 80$

Figura 28. Gráfico de Índice de Forma Média. 81

Figura 29. Gráfico de Distância Média ao Vizinho mais próximo. 82 
Figura 30. Gráfico de Área Núcleo Total por Classe.

Figura 31. Gráfico de Área da Classe vs Área protegida pela LPVN. $\quad 84$ Figura 32. Gráfico de Área da Classe vs Porcentagem de área protegida pela LPNV.

Figura 33. Matriz de Correlação gerada por cor e tamanho.

Figura 34. Matriz de correlação com a escala numérica de compatibilidade.

86

Figura 35. Espacialização das classes de fragmento e áreas protegidas pela LPVN. 


\section{Lista de tabelas}

Tabela 1. Sínteses das principais leis da LPVN 29

Tabela 2. Métricas utilizadas 34

Tabela 3. Caracterização de uso do solo na região da Baixada Litorânea.

44

Tabela 4. Porcentagem de Mata Atlântica em municípios abrangidos pela floresta.

Tabela 5. Dados selecionados para realização da pesquisa

Tabela 6. Metodologia e dados aplicados na espacialização das LPVN. 52 Tabela 7. Leis aprovadas nos municípios que fazem parte da APA do Rio São João visando sua conservação.

Tabela 8. Total de áreas protegido pela LPVN 68

Tabela 9. Métricas por Classe de fragmento. 73

Tabela 10. Segmentação da Paisagem por classe de tamanho. $\quad 74$ 


\section{Introdução}

A Mata Atlântica é considerada heterogênea em sua composição e está entre os cinco maiores hotspots do mundo, ainda que apresente infortúnios como: o desmatamento, conversão da paisagem natural em reflorestamento de espécies exóticas, plantações e pastagens, além da expansão industrial e urbana. Atualmente restam $12 \%$ desse bioma e que ainda contínua sendo tão expressivo em biodiversidade (SOS Mata Atlântica, 2018).

Esses fatores de modificação sobre este bioma datam desde o início do século XVI e estão associados ao conceito de "desenvolvimento", onde constituem as causas de perda de biodiversidade como: exploração desacerbada dos recursos naturais, degradação e destruição de habitats levando ao processo de fragmentação, ou seja, pequenas porções de Mata Atlântica por vezes isoladas que levam a poluição e introdução de espécies exóticas. O efeito disso é criar distanciamento, efeito de bordas e habitat matriz, processos que dificultam a interconectividade das pequenas porções de resquícios florestais (MacArthur e Wilson, 1967; Forman, 1995; Ribeiro, 2008).

De acordo com o Instituto SOS Mata Atlântica (2018), 18,7\% do território do Rio de Janeiro apresenta remanescentes florestais de Mata Atlântica, destaque vai para a Bacia do Rio São João, que registra a ocorrência do mico-leão-dourado, e apresenta um porcentual vivaz desses sobejos, porém, está severamente fragmentada. Observa-se que $80 \%$ dos remanescentes se encontram dentro de propriedades privadas.

A Bacia do Rio São João, que está localizada na porção leste do Estado do Rio de Janeiro, engloba oito municípios em sua porção geral, apresentando grande importância hídrica para baixada litorânea, ademais possui alto grau endêmico de espécies. Entre eles podemos dar notoriedade para o município de Silva Jardim por ser a maior porção dentro desse território. Silva Jardim apresenta grande prestígio no cenário da conservação ambiental devida ao REBIO de Poço da Antas, contudo, a maior área do município é ocupada por pequenas propriedades rurais, que refletem 
seu histórico de ocupação exploratória. Esses fatores levaram a composição de uma paisagem bem segmentada (Procópio de Oliveira et al, 2008).

A porção de Silva Jardim dentro da Bacia do Rio São João apresenta mais de 1000 fragmentos segundo a caracterização da paisagem realizada pela Fundação Brasileira para o Desenvolvimento Sustentável- FBDS em 2013. No trabalho realizado por Seabra, Vicens e M. Cruz, (2015), eles afirmam que os maiores remanescentes apresentam mais de $100 \mathrm{~m}^{2}$ e são mais contínuos nas vertentes íngremes, encontradas na porção norte. Em suas planícies e morrotes, principalmente na porção sul do município se apresenta os menores fragmentos meio a pastagens. Isso ocorre devido a todo processo de ocupação somado à implementação da BR-101 na região (Peixoto e Costa Junior, 2004; Abreu, 1994). 


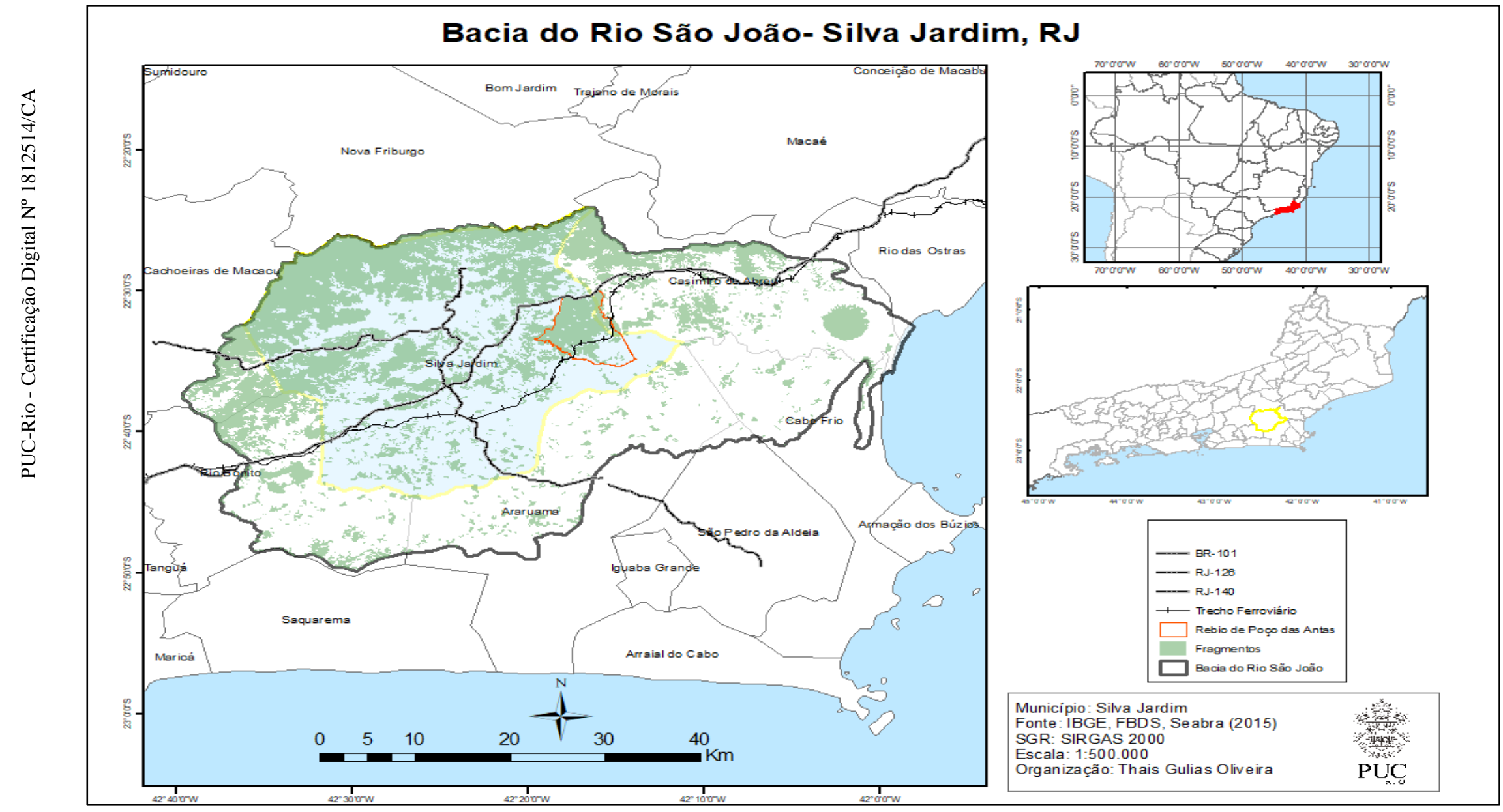

Figura 1. Localização da Bacia do Rio São João, RJ.

Fonte: Autora 
Pensar no cenário de cuidado dessa paisagem proporciona a conservação das espécies naturais, e, consequentemente, a manutenção de um bioma tão rico. Quando falamos da Bacia do Rio São João, pensamos na existência de áreas protegidas como: Área de Proteção Ambiental (APA), Reservas Biológicas, Reservas Naturais do Patrimônio Particular, além das leis de proteção dos recursos hídricos. Muitas delas ainda não possuem instrumentos de ordenação territorial ou existem apenas por meio de decretos de criação (Rio de Janeiro, 2017). A falta de um planejamento adequado e de uma gestão integrada do território proporciona a geração de conflitos frente aos interesses distintos da região. Pensar na forma de proteger e conservar essa área nos leva a Lei de Proteção da Vegetação Nativa, tendo a responsabilidade pela manutenção de processos ecológicos e conservação dos biomas brasileiros, essa se faz presente em todo território nacional.

O uso da Lei de Proteção a Vegetação Nativa aplicada a todo território nacional e monitorado pela Secretaria de Estado e Meio Ambiente (Sema), através das autodeclarações realizadas na plataforma do Sistema de Cadastro Ambiental Rural (SIMCAR), enfatiza proteger os remanescentes de vegetação nativa, recuperar as áreas deterioradas e garantir a conservação ambiental, deste modo redefinindo dois instrumentos de proteção importantes: as Áreas de Conservação Permanente (APP) e as Reservas Legais (RL). Ambas têm como objetivo a proteção de áreas de fragilidade e biomas dentro de propriedades públicas e privadas (Brasil, 2012).

Pensando que o poder público cria instrumentos legais de proteção ambiental com finalidade de preservar esses remanescentes, a forma mais eficiente e barata de aplicá-lo é através da espacialização do Lei de Proteção da Vegetação Nativa com o uso do geoprocessamento, ou seja, as técnicas de sensoriamento remoto e do sistema de informação geográfica (SIG). A utilização das técnicas de geoprocessamento para espacialização de cenários legais pode auxiliar na construção e nas análises do potencial de conectividades da paisagem e verificação da eficácia da aplicação da legislação (Issi et al. 2018).

Além disso, quando falamos de análise da paisagem heterogênea e processos de fragmentação, precisamos pensar na base no princípio da ecologia da paisagem. Essa ciência nos faz pensar em modelos que propõem a análise integrada dos 
aspectos sociais, legais e ambientais, utilizando múltiplas variáveis. Sendo assim, o SIG será um instrumento de análise e modelagem para as fontes de modelo que a Ecologia da Paisagem nos norteia.

Essa pesquisa se baseou nas perguntas norteadoras de que a aplicação de forma eficiente da Lei de Proteção a Vegetação Nativa dentro de um território permite a conservação dos elementos naturais da paisagem. Essas perguntas foram: 1- como o histórico de ocupação alterou a paisagem natural da região?; 2- como os fragmentos de vegetação natural estão dispostos no território onde há aplicação efetiva da Lei de Proteção a Vegetação Nativa?; e 3- o padrão estrutural destes fragmentos naturais proporciona condições favoráveis para a preservação da biodiversidade nas áreas onde temos maior eficiência da LPVN ou sua ausência?

Para responder as questões dessa pesquisa foi dividida em três etapas principais, sendo elas:

A primeira, consistiu em avaliar a evolução da paisagem através dos processos de ocupação que ocorreram em Silva Jardim espaço-temporalmente. Como esses processos impactaram na fragmentação da paisagem e como a ocupação dificulta o processo de gestão da área.

A segunda apresenta os materiais utilizados e etapas metodológicas. Os materiais consistem nos softwares e dados (destaque para os shapefiles selecionadas para atingir as respostas). A metodologia consistiu na espacialização da Lei de Proteção a Vegetação Nativa; as métricas de paisagem aplicadas nos fragmentos florestais do mapeamento de cobertura e uso; a construção de uma matriz de correlação para não haver dados ambíguos.

A última consistiu nos resultados e conclusões onde nos propomos a materializar as respostas para os objetivos dessa pesquisa.

Os resultados dessa pesquisa visaram contribuir para a elaboração de estratégias de recuperação e manejo dos fragmentos de vegetação nativa de biomas, e para as tomadas de decisão das políticas públicas locais de conservação ambiental de forma eficaz, eficiente e acessível. 
A presente pesquisa objetiva testar por meio de modelagem o potencial de conservação dos fragmentos pela Lei de Proteção da Vegetação NativaLPVN (Lei 12.651/12) dentro da bacia do Rio São João, utilizando o município de Silva Jardim como recorte.

Os objetivos específicos da pesquisa são:

- Entender e analisar as variáveis espaciais e processos históricos que levaram a fragmentação da área;

- Espacialização da Lei de Proteção da Vegetação NativaLPVN (Lei 12.651/12);

- Classificar e avaliar o potencial dos fragmentos para conservação; 


\section{Revisão conceitual}

\section{1}

\section{Da paisagem a Ecologia da Paisagem}

Paisagem é uma palavra muito ouvida e usada no senso comum. Segundo o dicionário Aurélio, Paisagem é: "Extensão de território que se abrange com um lance de vista. Desenho, quadro, gênero literário ou trecho que representa, ou em que se descreve um sítio campestre." Assim, todos, em algum momento, já se apropriaram da palavra paisagem para explicar ou exemplificar algum cenário. Ficando claro que está sempre ligado ao sentido da visão e da percepção daquele que se apropria da percepção.

Como citado, a paisagem é um dos objetos sujeitos a diversos olhares, tantos por geógrafos como por não geógrafos. Sauer acredita que a paisagem é conceitochave da geografia. A paisagem é a união de aspectos naturais e culturais relacionadas em área. Materialidade e extensão são particularidades primordiais da paisagem Saueriana, não aceitando como hipótese o uso do objeto como metáfora, como paisagem política ou econômica. As formas que compõem a paisagem estão constituídas entre si, demonstrando a atividade que origina uma estrutura. A paisagem se organizará em uma morfologia, na qual forma, função e estrutura são elementos centrais (Sauer, 1998-1925).

Diferente de Sauer, que vê a paisagem como morfológica, Cosgrove aponta ela como impregnação de símbolos: paisagem é um “modo de ver” (1985). Ela vai ser sujeita à interpretação de acordo com os diferentes olhares. A paisagem tem, assim, um sentido político, sendo um "poderoso meio através do qual sentimentos, ideias e valores são expressos" (1993). A paisagem vai refletir os sentimentos, essas ideias e esses valores.

Milton Santos, em a Natureza do Espaço (2003), diz que a paisagem vai além do que a visão abarca, mas é também percebida por outros sentidos. O autor exprime que a paisagem contém um grupo de formas e funções em permanente 
transformação. As formas e funções constroem a estrutura espacial, e geram um laço entre a paisagem e sociedade.

Há características relacionadas a diferentes abordagens sobre o conceito de paisagem, uma vez que que esse tem sido alvo de muitas interpretações ao longo do tempo (Troll, 1997). Aqui abordaremos o conceito de ecologia da paisagem.

O termo Ecologia da Paisagem, enquanto uma disciplina científica resultante, foi descrita por Troll em 1939 ao entender questões referentes ao uso da terra por meio de fotografias aéreas e análise das paisagens. Com a proposta desse termo, Troll teve o objetivo de incentivar um apoio entre a Geografia e a Ecologia estabelecendo, assim, na prática, a aproximação "horizontal" do geógrafo considerando a interação espacial dos fenômenos e com a aproximação "vertical" dos ecólogos, no estudo das interações funcionais de um dado lugar (Troll, 1939 apud Siqueira, 2013) .

Troll dialoga que há uma união entre a geografia e ecologia, então, é preciso entender o que é ecologia nessa lógica. Aqui cabe o estudo de Eugene Odum (1983) que declara ecologia como o estudo do "ambiente da casa", porque incluído todos os organismos contidos nela (incluindo o homem) e todos os processos funcionais que a tornam habitável.

Embora a ecologia permaneça radicada na biologia, ela já ganhou a maioridade com uma disciplina integrada essencialmente nova, que une os processos físicos e biológicos e serve de ponte entre as ciências naturais e as ciências sociais (Odum, 1988).

A Ecologia da Paisagem, então, vai se propor a analisar os processos naturais e sociais na paisagem, sendo vista como uma base científica para o planejamento, manejo, conservação, desenvolvimento e melhoria da paisagem. Ela sobrepujou os objetivos puramente naturais da bioecologia clássica e tem tentado incluir as áreas nas quais o ser humano é o centro da questão: sociopsicologia, economia, geografia e cultura (Metzger, 2001).

Besse (2014) aborda os aspectos físicos e morfológicos da paisagem, e como o homem atua nela. E explica que:

A paisagem também é o vento, a chuva, a água, o calor, o clima, as rochas, o mundo vivo, tudo o que cerca os seres humanos: resumindo, todo um meio ambiente cujas evoluções, na verdade, são afetadas, mais ou menos diretamente, pela ação, a emoção, e o pensamento humano; mas, afinal de contas, esse meio ambiente - somos 
também forçados a reconhecer - existe e se desenvolve sem o ser humano, estava aí antes dele e sobreviverá a ele de uma forma ou de outra.

Como já mencionado, Metzger (2001), ao discursar sobre ecologia da paisagem, em como o homem influência a paisagem e a gestão do território, vai de encontro a Troll. A ecologia da paisagem é uma ciência interdisciplinar que lida como as interações entre a sociedade humana e seu espaço de vida, natural e construído. O autor diz que antes a paisagem possui uma escala hierarquizada (população- comunidade- ecossistema- paisagem), logo o objetivo é a integração espacial entre as unidades da paisagem (natural e cultural) e criar uma relação horizontal.

Bertrand (1972) contribui com esse pensar ao integrar a paisagem natural e cultural.

A paisagem não é a simples adição de elementos geográficos disparatados. É, em uma determinada porção do espaço, o resultado da combinação dinâmica, portanto instável, de elementos físicos, biológicos e antrópicos que, reagindo dialeticamente uns sobre os outros, fazem da paisagem um conjunto único e indissociável, em perpétua evolução. (...) É preciso frisar bem que não se trata somente da paisagem "natural" mas da paisagem total integrando todas as implicações da ação antrópica.

Mais do que entender que a paisagem é composta de fatores naturais, ligados a ação ambiental, e fatores humanos, é preciso tentar integrar essas duas frentes como Troll, Bertrand, Metzger e Besse se propuseram a fazer. Não que seja fácil, mas é necessário para entender todas as dimensões que constroem a paisagem. Gray (2007) reafirma que é importante ter as camadas, mas é mais importante a necessidade de integrá-las.

A ecologia da paisagem se relaciona com o estudo de padrões da paisagem, e as interações das porções dentro de um mosaico. Com o objetivo de entender e analisar todas as porções, é necessário a aplicação dos indicadores da paisagem ou métricas de paisagem. Focado na análise dos padrões espaciais e a comparação de modelos, se pode melhorar as simulações de fenômenos em proporções maiores e gerir recursos naturais ao nível da paisagem (Duarte e Neves, 2008).

As métricas de paisagem são modelos quantitativos da composição da paisagem que assentem, dentro de um estabelecido contexto, descrever, por meio de indicadores numéricos, as componentes multidimensionais da paisagem. Ela pode ser dividida em duas categorias: as que quantificam a composição da 
paisagem, sem os atributos espaciais; e as que quantificam a composição da paisagem, com as informações espaciais. (McGarigal e Marks, 1994; Gustafson, 1998).

\section{2}

\section{Mata Atlântica}

A Mata Atlântica, ou floresta tropical úmida, é um dos maiores blocos contínuos de florestas tropicais. Distribuída por uma ampla faixa litorânea do Brasil sendo exposta a longos períodos de eventos físicos, químicos e ecológicos que foram responsáveis pela diversidade biológica desse bioma. Tendo sua amplitude do Rio Grande do Sul ao Rio Grande do Norte (Figura 2), temos uma floresta

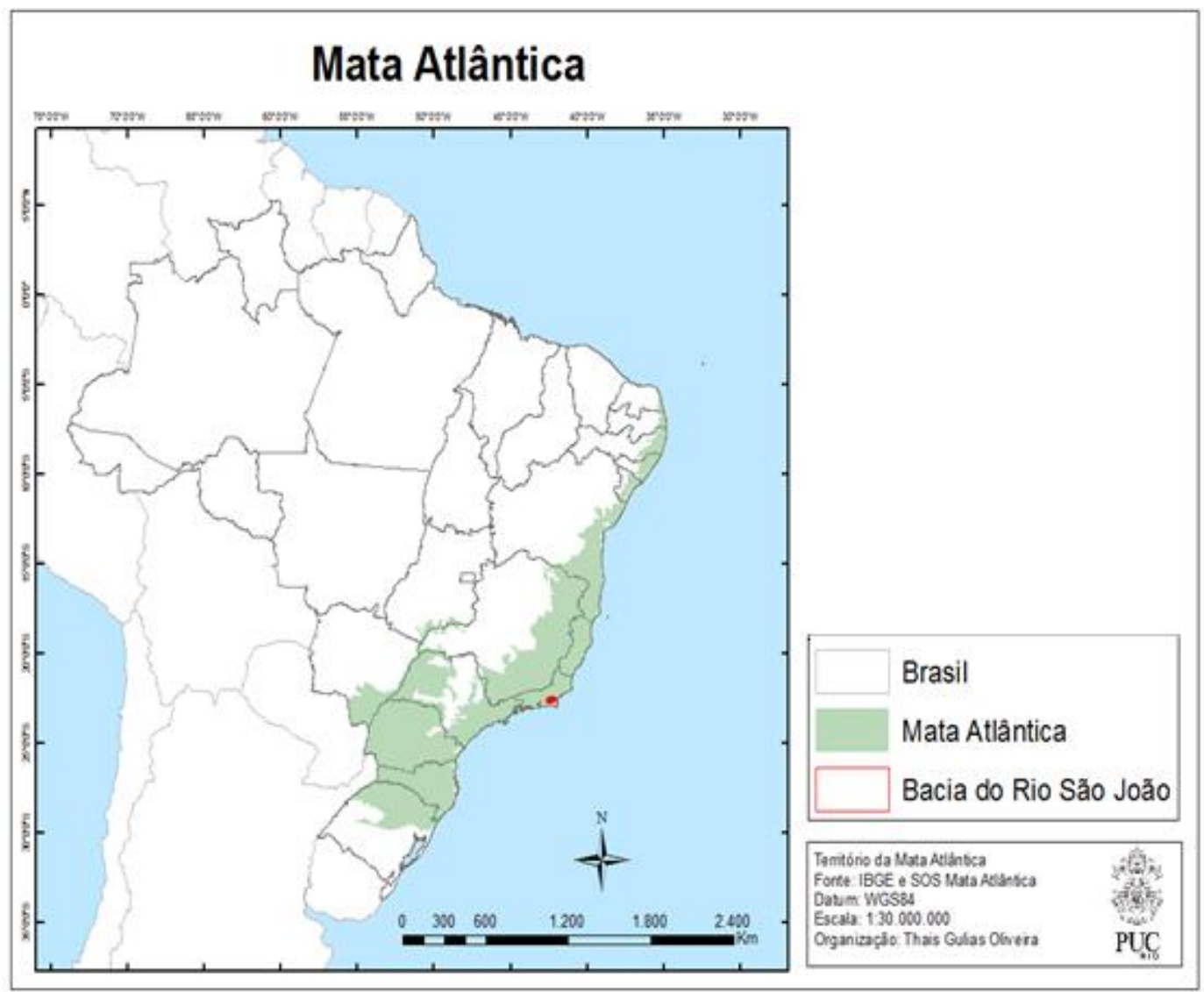

Figura 2. Localização da Mata Atlântica.

Fonte: Autora 
sofrendo com diferentes influências de latitude, assim sendo bem heterogênea em sua composição e rica em espécies endêmicas (Tabarelli et al. 2005).

Para entender a dinâmica de áreas naturais alguns autores se debruçam nos domínios morfoclimáticos. Por exemplo, Jurandir Ross (1995), que classificou a Mata Atlântica sendo uma floresta de encosta e semi-decidual do planalto atlântico, porém para essa pesquisa optamos por entender Mata Atlântica dentro do conceito de bioma.

O nome "Mata Atlântica" foi adotado devido à proximidade da floresta com o Oceano Atlântico. Sua formação exuberante ocorre devido à grande umidade de ar vinda dos ventos marítimos. Esses ventos, ao ganharem altitude, formam chuvas na costa. Ao longo do território sua classificação climática pode ser tropical, tropical de altitude ou subtropical, tendo temperaturas médias de 14 a $21^{\circ} \mathrm{C}$. Considerando a ampla distribuição latitudinal as temperaturas médias variam bem pouco, no sentido norte ao sul. Isso sucede da distribuição de calor das correntes oceânicas predominantes. Além da floresta tropical pluvial ou ombrófila, sua estrutura tem outras formações, como: florestas decíduas e semi-decíduas, manguezais, brejos, dunas, florestas de restinga, ilhas de vegetação rupestre nos afloramentos rochosos dos "inselbergs" (Franke et al 2005).

Alguns autores como Franke (2005) estimam o surgimento da Mata Atlântica há pelo menos 60 milhões de anos, visto que já existiam condições geoclimáticas para a formação da floresta. Os primeiros relatos sobre a Mata Atlântica por exploradores e naturalistas datam no início do século XVI. Esses se deparam com uma floresta tão grande e majestosa como algo que eles jamais tivessem visto antes, descrevem detalhadamente sobre a fauna e flora (Franke et al 2005).

A investigação histórica através de antigas publicações nos fornece informações sobre a distribuição geográfica de animais, plantas e populações. A primeira impressão que os colonizadores da América Portuguesa do século XVI tiveram sobre a Mata Atlântica, pode ser encontrada nas descrições de cartas, de relatos, de crônicas, de pinturas e de gravuras. Esse estudo analisa como as atividades humanas trazem consequências diretas nos ecossistemas, levando em consideração os fatores extrínsecos e intrínsecos que influenciam na modificação do espaço físico conhecido como Mata Atlântica. (Gregoleti et al. 2017) 
O território do Brasil, após essa descoberta, passa a ser um dos destinos mais desejados pelos exploradores e navegadores devido a suas riquezas naturais disponíveis em todo seu litoral. Essa região sofreu grande perda florestal e biológica desde o início da colonização. Segundo o Ministério do Meio Ambiente (2010) a Mata Atlântica, na chegada dos primeiros exploradores, era uma floresta extensa, densa e abundante de espécies ocupando $15 \%$ do território brasileiro por toda a faixa costeira.

Após longos anos de exploração e desmatamento para os ciclos da cana-deaçúcar e do café. Além disso, temos a ocupação de $60 \%$ população brasileira que até hoje em sua maioria é mais densa na faixa litorânea devido ao processo de ocupação estratégico que ocorreu desde a chegada dos Portugueses, que levou a construção de infraestrutura e estradas para conectar as outras regiões do país (Nunes, 2017). Observado os fatores acima entendemos como hoje a Mata Atlântica encontra-se em 18,7\% da sua composição em fragmentos florestais (SOS Mata Atlântica, 2018). Para muitos naturalistas o percentual de conservação era para ser maior justamente pela aplicação do Código Florestal.

As taxas de desflorestamento desafiam a legislação brasileira de proteção à Mata Atlântica. O código florestal de 1965 requer que $20 \%$ da área de qualquer propriedade rural na região seja manejada como reserva legal e que as matas de galeria (determinada pela largura do rio) e matas em encostas íngremes (por exemplo) sejam áreas de conservação permanente e preservadas como tal. (Schaffer e Prochnow, 2002)

Mesmo estando completamente fragmentado a Mata Atlântica é um dos principais hotspots do mundo, isso significa que ele concentra um número altíssimo de biodiversidade, seja nas espécies de fauna ou flora. Mesmo com o processo de desmatamento a floresta ainda abriga 2.300 espécies de vertebrados e 20.000 espécies de plantas vasculares. Estima-se que, aproximadamente, 740 espécies de vertebrados e 8.000 espécies de plantas vasculares sejam endêmicas, o que representa, respectivamente, $32 \%$ e $40 \%$ do total de espécies desses grupos no bioma (Mittermeier et al., 2004; Fonseca et al., 2004). Para os primatas, mais de 2/3 das espécies são endêmicas e, para espécies de plantas arbóreas, estima-se que 54\% sejam restritas ao bioma (Fonseca et al., 2004).

As regiões que se encontram protegidas são aquelas associadas às atuais unidades de conservação de proteção integral. No estado do Rio de Janeiro apesar 
de apresentar extensas redes de áreas protegidas mais de $90 \%$ dos remanescentes são menores de 100 hectares, evidenciando o processo de fragmentação da floresta. Muitos desses remanescentes também se encontram em terras privadas e a necessidade de estabelecer uma cooperação com eles é muito importante (MMA, 2002).

A SOS Mata Atlântica (2018) nos mostra que restam 12\% da cobertura original do bioma, porém esse ainda não perdeu 50\% de suas espécies, como seria esperado devido a tamanha exploração. Fonseca et al. (1997) afirma que os efeitos de fragmentação, mesmo que modifiquem as condições originais, não foram de todo sentidos, pois, ainda há algum nível de intercâmbio entre os indivíduos de cada unidade. Apesar disso, estudos como o de Tabarelli (2004) indicam que a fragmentação afeta a quantidade e qualidade dos habitats, tendo como resultado a dificuldade de sobrevivência de espécies, particularmente daquelas endêmicas e ameaçadas de extinção. Observando esses efeitos da fragmentação, principalmente nas florestas tropicais, que se mostram tão severos buscamos modos de atenuá-los, a principal ferramenta utilizada para desfragmentação é a implementação de corredores ecológicos, onde o principal benefício é o deslocamento de espécies nativas (Hilty et al., 2006).

O processo de desfragmentação é de grande importância para a Mata Atlântica, que apresenta grande relevância para a conservação do ciclo da água e conservação hidrográficas que alimentam os grandes centros urbanos. Por isso é necessário, mesmo com interesses de conflitos, assegurar as condições ecológicas para perpetuação de milhares de espécies que serão a herança das futuras gerações (Franke et al. 2005).

\subsection{1}

\section{Fragmentos Florestais}

Segundo Viana (1998), fragmentos florestais são áreas de vegetação natural interrompidas por barreiras antrópicas ou naturais capazes de reduzir, significativamente, o fluxo de animais, pólen ou sementes. A borda, o tipo de vizinhança, o grau de isolamento, o tamanho e a forma dos fragmentos, são os principais fatores a serem considerados quando forem analisados. 
A conservação dos remanescentes florestais é fundamental para garantir as peculiaridades da paisagem. Logo, a remoção de vegetação pode acarretar desequilíbrio ecológico para muitas espécies (Cunha e Guerra, 2003). Além disso, cada fragmento funciona como um histórico de cada região, e seus estados de conservação próprios tornam-se únicos, o que aumenta sua importância para a conservação (Morellato e Leitão Filho, 1995; Santos e Kinoshita , 2003).

E por que eles ocorrem? Wilcox e Murphy (1985) apontam que a expansão do uso da terra, que acompanha o crescimento da população humana, resulta na fragmentação dos habitats naturais com a formação de fragmentos florestais de diferentes tamanhos e formas. Essas alterações podem resultar no isolamento de populações e até extinção de espécies, reduzindo a biodiversidade local, em função dos impactos ambientais.

Segundo o Conama Nº01 de janeiro de 1986:

(...)o Impacto Ambiental é definido como qualquer alteração das propriedades físicas, químicas e biológicas do meio ambiente, causada por qualquer forma de matéria ou energia resultante das atividades humanas que, direta ou indiretamente, afetam a saúde, a segurança e o bem-estar da população; as atividades sociais e econômicas; a biota; as condições estéticas e sanitárias do meio ambiente; e a qualidade dos recursos ambientais (Brasil,1986).

Segundo Couto (2017) os impactos ambientais se refletem mais ainda nos processos de fragmentação florestal ao analisarmos os efeitos adversos como os de área, de borda, de distância (ou isolamento) e do seu arranjo espacial ou matriz. Vejamos cada um deles.

Efeito de Área: São mudanças ecológicas que ocorrem como resultado da área dos fragmentos e que se traduzem por menor riqueza de espécies e menor densidade de espécies. Os efeitos negativos à flora e à fauna tendem a ser mais bruscos nos fragmentos de menor volume. Acontecem principalmente na Mata Atlântica em seu processo de ocupação (Ranta, 1998).

Efeitos da Distância: A distância entre fragmentos, ou da floresta contínua, pode afetar o deslocamento de animais e estrutura que se desprende de uma planta adulta para dar origem a uma nova planta, como prega MacArthur e Wilson (1967) na "Teoria de Biogeografia de Ilhas". Quanto maior a distância, pior o efeito. 
Efeitos de Borda: Bordas são os limites do fragmento e formam uma transição abrupta entre a floresta e a paisagem vizinha modificada. Os efeitos negativos são: alterações abióticas, na abundância das espécies e em processos ecológicos. Conforme o tamanho do fragmento terá influenciado em sua forma, graças à relação perímetro/área. Alguns efeitos de bordas são: aumento da taxa de mortalidade de árvores; mudanças bruscas de luminosidade, temperatura, umidade e ventos; extinção de espécies de insetos, pássaros e outros animais; e deixa a floresta mais suscetível à invasão por espécies exóticas ou não florestais (Ribeiro, 2008).

Efeitos da matriz da paisagem: Refere-se ao mosaico de habitats modificados pelo homem, tais como pastagens, culturas, plantações ou florestas em regeneração que circundam os fragmentos de floresta (Forman, 1995). Estudos realizados por Gascon et al. (1999) e Stouffer e Borges (2001), comprovaram que os efeitos de matriz prejudicaram sensivelmente as populações de formigas, pássaros e sapos.

Pensando nisso, o arranjo físico da paisagem é referente aos elementos que a produzem (McGarigal e Marks, 1994), e os índices da paisagem colaboram para o compreender da espacialização dos fragmentos e seus graus de fragmentação.

\section{3}

\section{A origem do Código Florestal a Lei de Proteção da Vegetação Nativa}

Muitos têm em mente que as primeiras leis que visavam a restrição da exploração dos recursos naturais, ou seja, realização da extração vegetal, principalmente das florestas brasileiras, datavam do século XX. Porém a primeira lei veio do Brasil Colônia, onde a corte se preocupava com sua hegemonia na exploração dos recursos naturais em sua colônia. Esse precursor do primeiro Código Florestal tinha como caráter absoluto a concentração de renda das elites e a rentabilidade da coroa Portuguesa (Sparovek et al., 2010).

Apesar de leis em prol do controle de extrativismo vegetal surgir no século XVII, o primeiro Código Florestal Brasileiro surgi nos anos 30, juntamente com a Constituição de 1934, sancionadas pelo presidente Getúlio Vargas. Na década de 30 o Brasil ainda refletia as perdas da a crise 29 na bolsa norte-americana e iniciava seu processo de industrialização. $\mathrm{O}$ investimento em Indústrias de base que incluem mineradoras, petrolíferas e madeireiras que usavam de recursos naturais para sua 
matéria-prima. Pensando nisso era necessário regulamentar as normas de extração dos bens naturais para não acarretar seu esgotamento (Filho et al. 2015).

Para Vargas era preciso a criação de leis que controlassem a exploração dos bens naturais, assim surgi o primeiro Código Florestal Brasileiro. $\mathrm{O}$ artigo que mais marcou o Código Florestal de 34 foi a delimitação de uma área mínima de 25\% do total de propriedades privadas destinados às reservadas florestais. Analisando seus artigos fica claro que o Código de 34 pauta sua essência em proteger as áreas florestais, tanto do domínio público, quanto dos privados (Filho et al. 2015).

Ao longo dos anos seguintes o Código Florestal foi sofrendo diversas modificações. Em 1962, surgiu a proposta da criação de um novo Código capaz de reforçar as ideias de conservação ambiental, então três anos depois o Presidente Castelo Branco decreta a criação do Código Florestal de 65. O Código se destaca pela criação das Reservas Legais (RL) e das Áreas de Preservação Permanente (APP's) (Filho et al. 2015).

\begin{abstract}
A Reserva Legal é a porcentagem de cada propriedade ou posse rural que deve ser preservada, variando de acordo com a região e o bioma. O código determina a ampliação dos tamanhos das reservas: (...)e $20 \%$ em todos os biomas das demais regiões do País. As Áreas de Preservação Permanente têm a função de preservar locais frágeis como beiras de rios, topos de morros e encostas, que não podem ser desmatados para não causar erosões e deslizamentos, além de proteger nascentes, fauna, flora e biodiversidade, entre outros. (Filho et al. 2015)
\end{abstract}

Após 47 anos o Brasil tem um novo Código Florestal, conhecido como Lei de Proteção da vegetação Nativa (LPVN). As importantes alterações nesse "mais novo" Código consideravam às definições de Reserva Legal (RL), Área de Conservação Permanente (APP) e a inserção de dois instrumentos: o Cadastro Ambiental Rural (CAR) e o Programa de Regularização Ambiental (PRA) (Brasil, 2012).

Analisando a Lei de Proteção da Vegetação Nativa (LPVN), denominada popularmente de Novo Código Florestal Brasileiro (Lei n ${ }^{\circ} 12.651 / 12$ ), tem como principais pontos a proteção ambiental, objetivando proteger os remanescentes de vegetação nativa, recuperar as áreas deterioradas e garantir a conservação ambiental. Desse modo, foram redefinidos dois instrumentos de proteção 
importantes: as Áreas de Preservação Permanente (APP) e as Reservas Legais (RL).

As APP, de acordo com a legislação, são

(...)áreas cobertas ou não por vegetação nativa, com função ambiental da preservação dos recursos hídricos, paisagem, estabilidade geológica, biodiversidade, facilitar o fluxo gênico de fauna e flora, protegendo o solo e garantindo o bem-estar das populações humanas (art $3^{\circ}$ II. Brasil, 2012)

Reserva legal ficou estabelecido como:

(...)área localizada no interior de uma propriedade ou posse rural com a função de assegurar o uso econômico de modo sustentável dos recursos naturais do imóvel rural, auxiliar a conservação e a reabilitação dos processos ecológicos e promover a conservação da biodiversidade, bem como o abrigo e a proteção da fauna silvestre e da floresta nativa. (art $3^{\circ}$ III. Brasil, 2012).

Esses modos de proteção ocorrem, sobretudo, por serem áreas que assumem o compromisso de manutenção dos processos ecológicos que exercem inúmeros serviços ambientais, como a conexão de áreas e a manutenção da diversidade gênica animal e vegetal (Metzger, 2010). Para mais, são áreas vulneráveis ou ambientalmente frágeis, que compreende as margens dos rios, áreas de declividades íngremes, topos de morro, faixas litorâneas (Tabela 1) (Coutinho et al., 2013).

Tabela 1. Sínteses das principais leis da LPVN

\begin{tabular}{|c|c|}
\hline \multicolumn{2}{|c|}{ Interpretação da Lei de Proteção da Vegetação Nativa (LPVN)/ (Lei no 12.651/12) } \\
\hline APP de nascente & Raio de $50 \mathrm{~m}$ \\
\hline APP de cursos d'água & $\begin{array}{l}30 \mathrm{~m} \text { na faixa marginal de cursos } \\
\text { d'água com largura até } 10 \mathrm{~m} ; 50 \mathrm{~m} \text { na faixa } \\
\text { marginal de cursos d'água com largura de } 10 \text { a } \\
50 \mathrm{~m} ; 100 \mathrm{~m} \text { na faixa marginal de cursos d'água } \\
\text { com largura de } 50 \text { a } 200 \mathrm{~m}\end{array}$ \\
\hline $\begin{array}{l}\text { APP de lagos e lagoas } \\
\text { naturais }\end{array}$ & $\begin{array}{l}50 \mathrm{~m} \text { na faixa marginal de lagos e lagoas de } 1 \text { a } \\
20 \text { ha (inseridos em zona rural); } 100 \mathrm{~m} \text { na faixa } \\
\text { marginal de lagos e lagoas maiores que } 20 \text { ha } \\
\text { (inseridos em zona rural); } 30 \mathrm{~m} \text { na faixa } \\
\text { marginal dos lagos e lagoas (inseridos em área } \\
\text { urbana) }\end{array}$ \\
\hline APP de brejo/veredas & $\begin{array}{l}50 \mathrm{~m} \text { na faixa marginal a partir do espaço } \\
\text { permanentemente brejoso e encharcado }\end{array}$ \\
\hline APP de reservatórios de água artificial & $\begin{array}{l}\text { Faixa conforme definição da licença ambiental } \\
\text { do empreendimento }\end{array}$ \\
\hline $\begin{array}{l}\text { APP de reservatórios de água artificial } \\
\text { destinado a geração de energia ou } \\
\text { abastecimento público }\end{array}$ & $\begin{array}{l}\text { Faixa mínima de } 30 \text { m e máximo de } \\
100 \text { m (inseridos em área rural); Faixa mínima } \\
\text { de } 15 \text { m e máximo de } 30 \text { m (inseridos em área } \\
\text { urbana); Distância entre o máximo operativo } \\
\text { normal e a cota máxima (registrado, com } \\
\text { autorização ou } \\
\text { contrato de concessão assinado antes de 2001) }\end{array}$ \\
\hline
\end{tabular}




\begin{tabular}{ll}
\hline APP de Topo de Morro & $\begin{array}{l}1 / 3 \text { maior de morros e montanhas, com altura } \\
\text { maior que } 100 \mathrm{~m} \text { e declividade maior que } 25^{\circ}\end{array}$ \\
\hline APP de Linha de Cumeada & $\begin{array}{l}1 / 3 \text { maior da altura em relação a base, do pico } \\
\text { mais baixo da cumeada distantes em pelo } \\
\text { menos } 1000 \mathrm{~m}\end{array}$ \\
\hline APP de encostas & $\begin{array}{l}\text { Encostas ou partes destas com declividade } \\
\text { superior a } 45^{\circ} \text { (equivalente a 100\%) na linha de } \\
\text { maior declive }\end{array}$ \\
\hline Reserva legal & $20 \%$ da área do imóvel rural \\
\hline
\end{tabular}

\section{4}

Geoprocessamento

O geoprocessamento pode ser determinado como um bloco de técnicas relacionadas à coleta, ao armazenamento, ao tratamento e a arguição de informações espaciais que permite o desenvolvimento regular de novos sistemas e aplicações que auxiliam em tomadas de decisões. Este conjunto de tecnologias, também conhecida por Geotecnologias, agrupa a topografia, a geodesia, a fotogrametria, a cartografia, o banco de dados geográficos, os Sistemas de Posicionamento Global (GPS), os Sistemas de Informação Geográfica (SIG) e o Sensoriamento Remoto (SR) (Rosa e Brito, 1996; Câmara e Davis, 2001)

A utilização dessas tecnologias espaciais é descriminada, fundamentalmente, por uma máquina, um programa e por técnicos que os manipulam e são os responsáveis por analisar os dados, além decidir as metodologias adequadas. Esses três elementos, em comunhão, constituem em poderosas ferramentas de análise, diagnóstico, planejamento estratégico e gestão de recursos de maneira concreta a tomada de pareceres (Câmara e Davis, 2001; Rosa, 2005). O geoprocessamento permite a exposição de dados basicamente em cinco tipos, sendo eles: dados temáticos, dados cadastrais, redes, modelos numéricos de terreno e imagens.

Os dados temáticos demostram a distribuição espacial de uma determinada área georreferenciada, expressa de forma qualitativa ou quantitativa, como os mapas de uso e cobertura da terra, de pedologia, de declividade e de capacidade de uso da terra; os dados cadastrais expõem aos atributos dos dados (armazenados em um banco de dados), que podem ser afiliados a diversas representações gráficas; os dados de rede, são representados em dados vetoriais associados às informações de rede de drenagem, malha viária e serviços de utilidades públicas (como as redes e linhas de transmissão de energia e de água); os modelos numéricos de terreno, são 
modelos matemáticos capazes de representar uma área real a partir de dados quantitativos, como os dados de altimetria para gerar mapas topográficos e demonstrações tridimensionais; e, por fim, as imagens, que são obtidas por meio de sensores, acoplados em aeronaves ou satélites, representando dados de forma matricial (Burrough, 1986).

$\mathrm{Na}$ perspectiva da tecnologia, o uso do SIG e do SR tem auxiliado no crescimento de pesquisas com perspectivas de conservação dos recursos naturais. O SIG permite a composição de um ambiente de gerenciamento de arquivos georreferenciados, e o SR através da equiparação entre bandas espectrais (Ahamed et al., 2011; Lopes e Reuss-Strenzel, 2015).

Lembrando que, a partir da década de 80, ocorreu o crescimento da preocupação acerca da conservação dos recursos biológicos, principalmente na faixa dos trópicos, onde se detém a maior riqueza de biodiversidade (Velazquez e Bocco, 1994). Em relação a essa biodiversidade ameaçada, é necessário traçar um plano de estratégia de conservação efetivo. Porém, devido à complexidade de avaliações espaciais precisas da distribuição territorial das espécies, essas estratégias passam por grande dificuldade. $\mathrm{O}$ uso do geoprocessamento como ferramenta analítica para tratar informações georreferenciadas também possibilita a manipulação de diversas fontes, mostrando, assim, um enorme valor para estudos ambientais. Devida a sua capacidade de integração de variáveis, é possível aperfeiçoar projetos de biologia da conservação e gestão da biodiversidade (Menezes, 2013).

Pensando no sentido da conservação da Mata Atlântica, em soma com a Lei de Proteção da Vegetação Nativa, é possível definir os limites de distribuição das áreas remanescentes de floresta e mapeamento das áreas dentro de propriedades privadas. A Cartografia Digital, fazendo uso correto de uma projeção cartográfica que vise manter, de maneira mais fidedigna, as formas e as áreas, permite que sejam feitos cálculos com maior precisão dessas informações geográficas e, assim, que elas sejam armazenadas em um banco de dados espacial. Com um conjunto de dados é possível criar uma sobreposição/organização com qualidade cartográfica, determinando os valores das generalizações para, assim, se definir as áreas de prioridade para conservação e estratégias de gestão da paisagem (Menezes, 2013). 
Os autores abaixo utilizam justamente essa proposta de utilização do geoprocessamento para otimizar o trabalho de gestão da paisagem. Por exemplo, Seabra (2015) realizou a analise espaço- temporal de ocupação e propôs a recuperação através das técnicas de geoprocessamento aplicadas no município de Silva Jardim. Andrade (2012) avaliou os fragmentos florestais utilizando imagens do Google Earth e o ArcGIS, classificando a vegetação dentro de blocos de $2 \mathrm{~km} \mathrm{x}$ $2 \mathrm{~km}$ na região de Mariana e Ouro Petro. Lopes (2015) mapeou e caracterizou o uso do solo para identificar as causas de conflitos ambientais dentro da APA de Guaibim.

\section{5}

\section{Métricas de paisagem como indicadores}

A análise dos padrões da fragmentação florestal pode acontecer por meio das métricas da paisagem, técnica utilizada pela disciplina de Ecologia da Paisagem para quantificar e qualificar as manchas por índices como: o tamanho do fragmento, a área core, a forma e o grau de isolamento dos fragmentos (Duarte e Neves, 2008; McGarigal e Marks, 1994).

A concepção de estrutura da paisagem foi vigorosamente definida por ferramentas computacionais, principalmente pelo Sistema de Informações Geográficas (SIG) e com o processamento de imagens. Portanto, para entender os paradigmas da estrutura da paisagem, foi criado um grupo de métodos de medidas da estruturação da paisagem (landscape metrics) (Lang e Blaschke, 2009) descrito como métricas da paisagem empregada para quantificar os padrões espaciais meio de ferramentas de análise espacial.

Propagada a partir do ano de 1994, concebida pelo Professor McGarigal, PhD em Ciência Florestal, e pela programadora Barbara Marks, na Universidade do Estado do Oregon e ofertado gratuitamente pela internet, o software que apresenta um papel satisfatório na área de Ecologia da Paisagem (McGarigal e Marks, 1994).

Inspirados no pioneirismo de McGarigal e Marks, o V- Late é uma extensão das ferramentas de análise da paisagem, sendo um script, ou seja, um roteiro de sistema de execução de forma automatizada a aplicação das métricas programas para serem ativadas por um operador, e propõe as análises através da orientação de vetores. Ele foi criado no ano de 2003 por uma equipe do Grupo de Pesquisa em 
Gestão de Paisagens e Recursos, da Universidade de Salzburg, Áustria, e, dirigido por Dirk Tiede, no marco do projeto de investigação europeu denominado SPIN, ou em tradução livre, Indicadores Espaciais para Conservação da Natureza (Lang, 2003).

Com o presente layout abaixo, ele contém um conjunto específico de métricas que levam a descrição de cálculos em registros poligonais da estrutura, sendo elas: área, densidade e tamanho, borda, forma, proximidade e área core. Esse conjunto de métricas descrevem a forma, configuração e composição do padrão da paisagem e são considerados para cobrir os principais aspectos da avaliação estrutural da paisagem de grande importância ecológica. Observe que o V-Late também oferece um pequeno arquivo de ajuda que descreve brevemente as métricas implementadas (Lang, 2003).

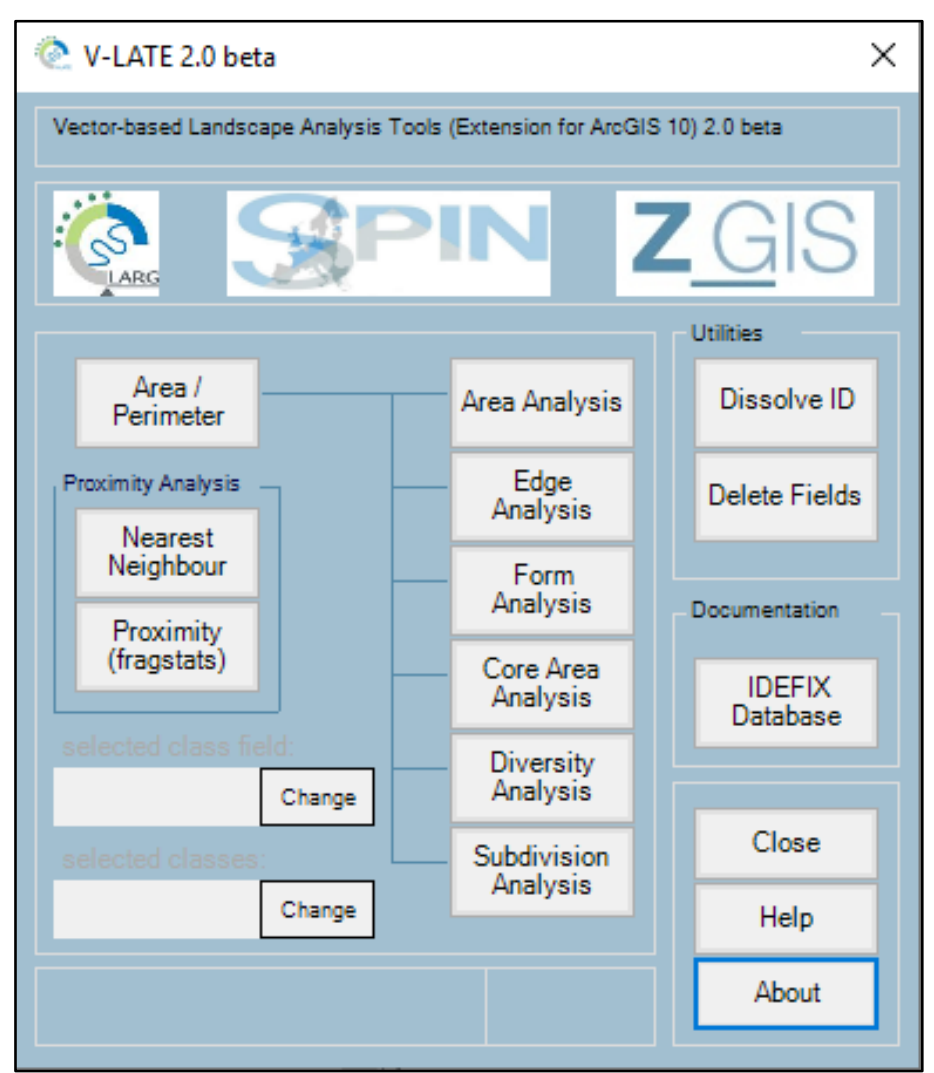

Figura 3. Interface do V-Late com as métricas de paisagem.

Fonte: Lang, 2003 
De acordo Lang (2003) seu objetivo era criar um script capaz de realizar a análise por meio de orientação de vetores, oposto de produtos similares já existentes de descrição da estrutura da paisagem. Embora tenha sido desenvolvido para conservação da natureza, o pacote V-Late também pode ser usado para qualquer outra análise de estrutura espacial (Lang, 2003).

Tabela 2. Métricas utilizadas

\begin{tabular}{|c|c|c|c|c|}
\hline Grupo & Sigla & Unidade & Métrica & Descrição \\
\hline \multirow[t]{2}{*}{ Área } & $\mathrm{CA}$ & $\mathrm{m}$ & Área da classe & $\begin{array}{l}\text { Somatório das áreas de todas } \\
\text { as } \\
\text { manchas. }\end{array}$ \\
\hline & $\mathrm{PP}$ & $\%$ & $\begin{array}{l}\text { Porcentagem da } \\
\text { Paisagem }\end{array}$ & $\begin{array}{l}\text { Porcentagem de cobertura } \\
\text { com relação ao total da } \\
\text { paisagem. }\end{array}$ \\
\hline \multirow[t]{3}{*}{$\begin{array}{l}\text { Densidade e } \\
\text { Tamanho }\end{array}$} & NP & Adimensional & $\begin{array}{l}\text { Número de } \\
\text { manchas }\end{array}$ & $\begin{array}{l}\text { Número total de manchas. } \\
\text { Maior valor representa } \\
\text { fragmentação da paisagem e } \\
\text { menor valor, adesão ou } \\
\text { extinção de fragmentos da } \\
\text { mesma classe. }\end{array}$ \\
\hline & MPS & $\mathrm{m}$ & $\begin{array}{l}\text { Tamanho médio } \\
\text { da mancha }\end{array}$ & $\begin{array}{l}\text { Indica o grau de } \\
\text { fragmentação por função do } \\
\text { número de fragmentos e da } \\
\text { área total ocupada por } \\
\text { determinada } \\
\text { Fragmentos de tamanhe } \\
\text { maiores apresentam maior } \\
\text { diversidade, uma vez que a } \\
\text { riqueza das espécies depende } \\
\text { das dimensões dos } \\
\text { fragmentos. }\end{array}$ \\
\hline & PSSD & $\mathrm{m}$ & $\begin{array}{l}\text { Desvio padrão } \\
\text { do tamanho da } \\
\text { mancha }\end{array}$ & $\begin{array}{l}\text { Razão da variância do } \\
\text { tamanho das manchas. } \\
\text { Valores de área altos } \\
\text { apresentam fragmentos com } \\
\text { tamanho muito acima da } \\
\text { média, e valores de área } \\
\text { baixos apresentam } \\
\text { fragmentos com tamanhos } \\
\text { abaixo da média. }\end{array}$ \\
\hline \multirow[t]{2}{*}{ Borda } & TE & $\mathrm{m}$ & Total de bordas & $\begin{array}{l}\text { Soma de perímetro de todas } \\
\text { as manchas. Quanto mais } \\
\text { próximo de zero mais forte é } \\
\text { o efeito de borda. }\end{array}$ \\
\hline & ED & $\mathrm{m} / \mathrm{ha}$ & $\begin{array}{l}\text { Densidade de } \\
\text { bordas }\end{array}$ & $\begin{array}{l}\text { Comprimento total de bordas, } \\
\text { dividido pela área total da } \\
\text { paisagem. Maior valor expõe } \\
\text { maior efeito de borda. }\end{array}$ \\
\hline Forma & MSI & Adimensional & Índice de forma & $\begin{array}{l}\text { Será igual a } 1 \text { quando } \\
\text { apresentar forma simples } \\
\text { (circunferências) e chegará a } \\
2 \text { quando a forma for mais } \\
\text { complexa. }\end{array}$ \\
\hline
\end{tabular}




\begin{tabular}{|c|c|c|c|c|}
\hline Proximidade & MNN & $\mathrm{m}$ & $\begin{array}{l}\text { Distância média } \\
\text { ao vizinho mais } \\
\text { próximo }\end{array}$ & $\begin{array}{l}\text { Esse índice informa o grau de } \\
\text { isolamento da mancha e } \\
\text { depende do } \\
\text { número, tamanho e a } \\
\text { distância que se encontram as } \\
\text { outras manchas do mesmo } \\
\text { tipo, localizadas dentro de } \\
\text { um raio determinado. Os } \\
\text { valores são iguais a } \\
\text { zero quando não existe } \\
\text { nenhuma mancha do mesmo } \\
\text { tipo dentro do raio } \\
\text { determinado e aumenta na } \\
\text { medida em que cresce o } \\
\text { número de manchas, e seu } \\
\text { tamanho e a distância entre } \\
\text { elas se fazem menores }\end{array}$ \\
\hline
\end{tabular}

\begin{tabular}{lllll}
\hline Área Core & TCA & $\mathrm{m}$ & $\begin{array}{l}\text { Área Núcleo } \\
\text { Total da Classe }\end{array}$ & $\begin{array}{l}\mathrm{O} \text { tamanho total de áreas } \\
\text { núcleo dentro da paisagem ou } \\
\text { dentro de cada fragmento ao } \\
\text { nível de classe }\end{array}$ \\
&
\end{tabular}

Fonte: Adaptação de Lang, 2003

Como já relatado, o uso de ferramentas computacionais vem sendo aplicado nos estudos de fragmentos desde os anos 90. Atualmente, com a maior acessibilidade aos computadores, esse uso vem se intensificando e algumas análises em diferentes paisagens foram realizadas.

Souza et al. (2014) e Andrade et al. (2012), utilizaram do software como ferramenta para aplicação de métricas caracterizando os fragmentos para a criação de cenários futuros de restauração ecológica.

Toppa et al. (2013) caracterizou os fragmentos de Mata Attântica a fim de subsidiar as demandas de conservação do plano de manejo de um parque estadual, e obteve como conclusão que as métricas de tamanho dos fragmentos, índice de forma, área nuclear para uma borda de $30 \mathrm{~m}$, índice de conectividade para $100 \mathrm{~m} \mathrm{e}$ distância do vizinho mais próximo são bons avaliadores, visto que identificaram os fragmentos com alto grau de conectividade que por consequência favoreciam a biodiversidade existente no parque. 
Abdalla e Cruz (2015), relatam que as métricas serviram para:

As métricas de forma revelaram a tendência geral de fragmentos bastante irregulares, o que sugere maior vulnerabilidade quanto ao efeito de borda. As métricas de borda indicaram menores efeitos de bordas nos fragmentos médios e grandes, o que revela maior conservação da biodiversidade desses fragmentos. As métricas de área central complementam a ideia de os fragmentos florestais com tamanhos maiores estarem menos vulneráveis, visto que o tamanho das áreas centrais desses fragmentos torna esses fragmentos ecologicamente viáveis, fazendo a compensação dos efeitos de bordas. As métricas de proximidade indicaram uma proximidade global dos fragmentos, efeito este promovido pelos fragmentos muito pequenos, o que facilita as interações ecológicas da flora e a circulação da fauna.

Pires et. al (2015) concluiu que as métricas da paisagem eram um importe e rápido métodos para avaliar os cenários referentes aos remanescentes florestais.

Silva et al. (2015), através da aplicação das métricas de área, borda e proximidade identificou que a área de estudo dentro das Unidades de Conservação realmente se encontra bem preservados. 
Identificação de análise dos processos históricos da fragmentação de Silva Jardim, RJ

A bacia hidrográfica do Rio São João está localizada no Estado do Rio de Janeiro, sudeste brasileiro, entre as coordenadas $22^{\circ} 20^{\prime}$ e $22^{\circ} 50^{\prime}$ sul de latitude e $42^{\circ} 00^{\prime}$ e $42^{\circ} 40^{\prime}$ oeste longitude. Apresenta cerca de $2.113 \mathrm{~km}^{2}$ de área, englobando oito municípios: Silva Jardim (43, 52\%) (Figura 4), Casimiro de Abreu (16,30\%), Araruama (16, 26\%), Rio Bonito (11,94\%), Cabo Frio $(8,7 \%)$, Cachoeiras de Macacu (2,46\%), Rio das Ostras $(0,44 \%)$ e São Pedro da Aldeia (0,44\%) . Estando inserida na região do Estado denominada "Baixada Litorânea, Microrregião da Bacia do São João". Sendo seu bioma e ecossistema classificados como Floresta Ombrófila Densa e Mata Atlântica e baixada (ICMBio,2008).

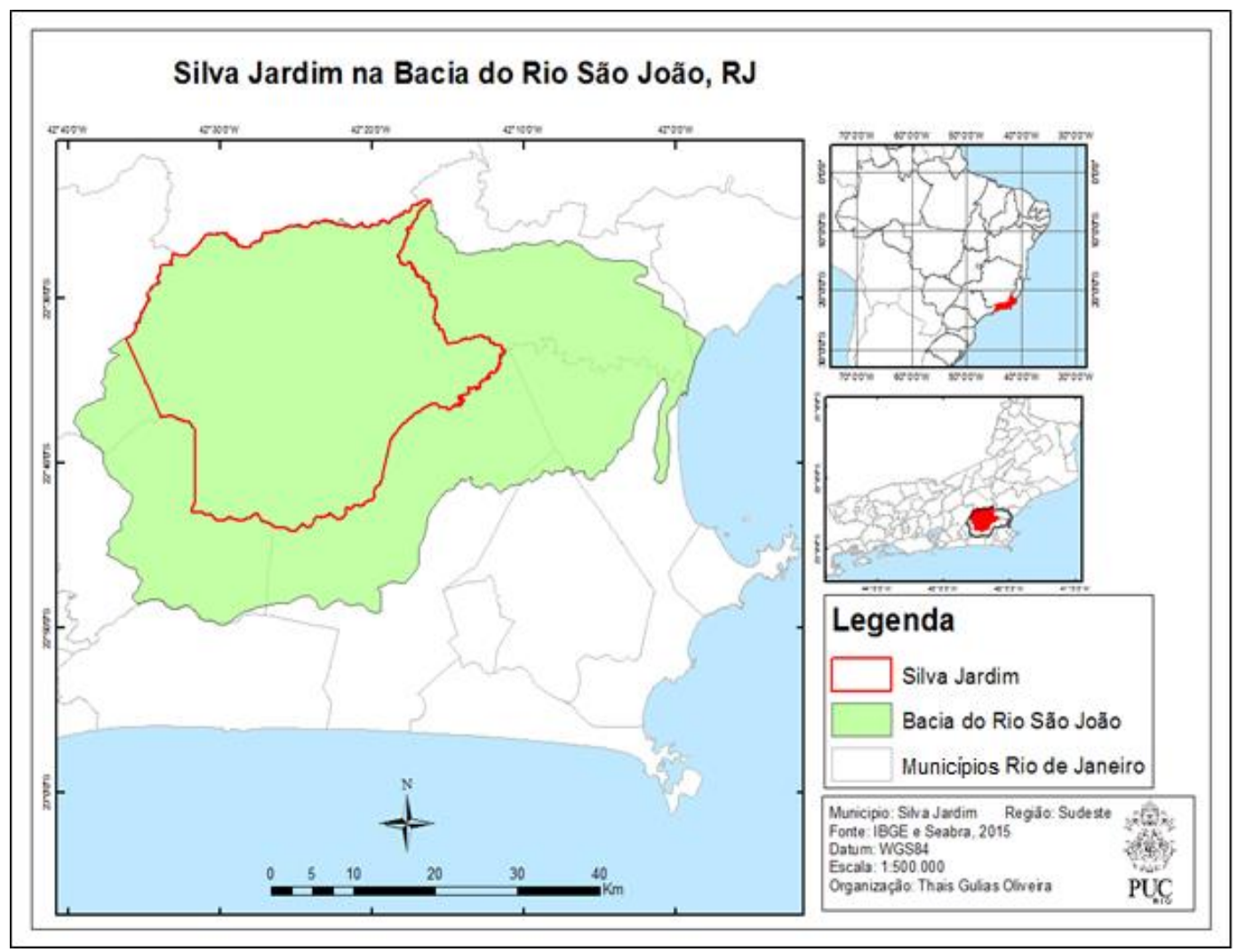

Figura 4. Delimitação de Silva Jardim dentro da Bacia do Rio São João, RJ. Fonte: Autora 
O recorde espacial dessa pesquisa consiste no município de Silva Jardim, que é o maior município dentro da Bacia do Rio São João. Os primeiros relatos sobre o Município de Silva Jardim datam de meados do século XVIII, porém há grandes controvérsias sobre sua origem. Localizado na região das Baixada Litorânea do Rio de Janeiro, microrregião da bacia do Rio São João, apresenta limites territoriais com diversos municípios: ao norte de Nova Friburgo, ao sul Araruama, a leste Casimiro de Abreu, a oeste Rio Bonito e a noroeste de Cachoeiras de Macacu. Localizada nas coordenadas geográficas 22 graus 39' 03" latitude sul e 42 graus 23' 30" longitude oeste. Divide seu território em quatro distritos: Silva Jardim-sede, Aldeia Velha, Gaviões e Correntezas (IBGE, 2010) (Figura 5) .

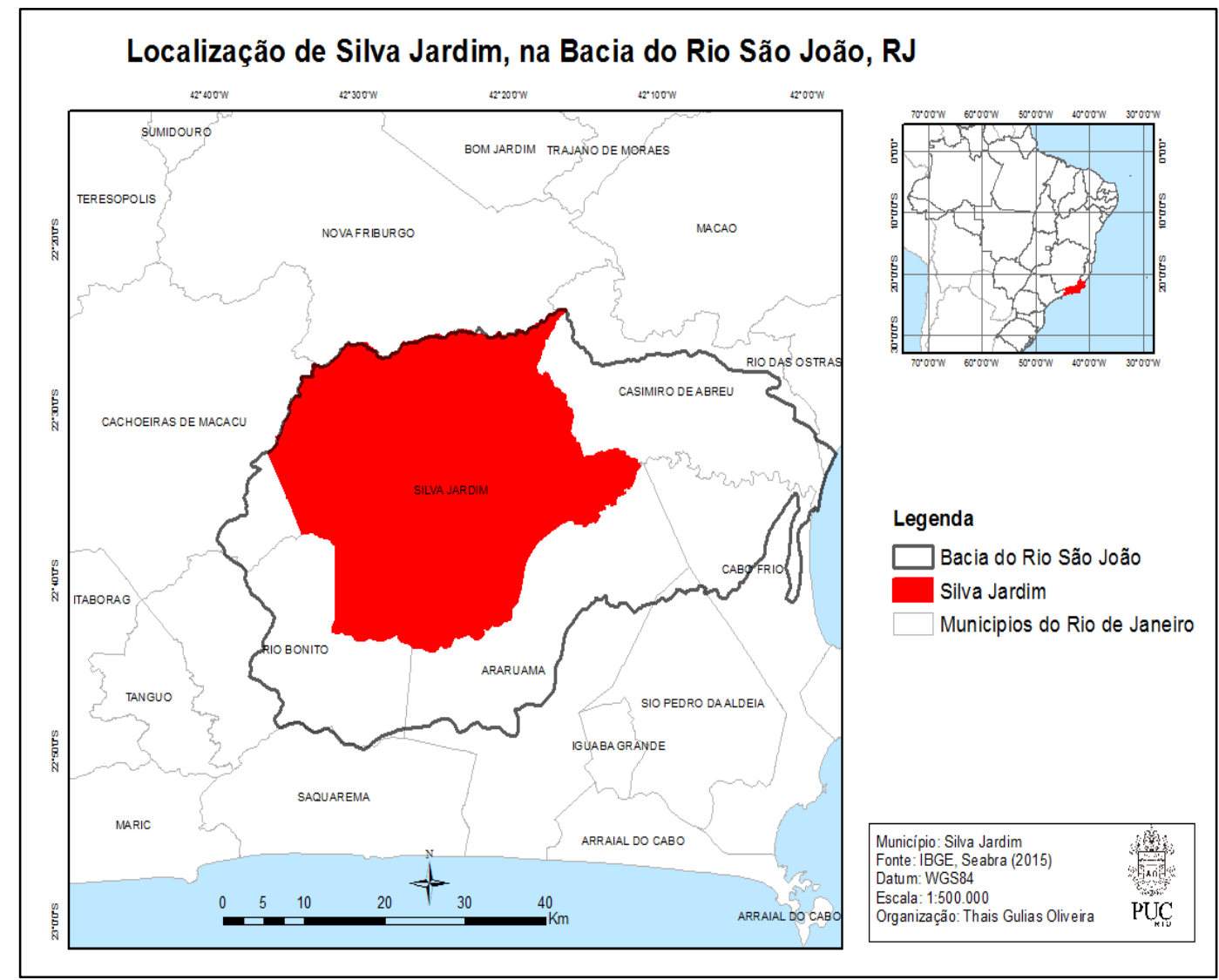

Figura 5. Localização de Silva Jardim, na Bacia do Rio Sâo João.

Fonte: Autora 
Tendo sua área urbana ocupando apenas $0,4 \%$ do município, essa ocupação territorial é caracterizada, majoritariamente, por pequenas propriedades rurais dedicadas às atividades agropecuárias (IBGE, 2010).

O município chama atenção por possuir grande parte de seu território protegido por reservas ambientais devido à preocupação com a conservação da Mata Atlântica, que foi muito explorada, principalmente, no século XVIII e XIX. E a proteção do mico-leão-dourado, que é considerada uma espécie bandeira por sua atratividade (aparência). Mamíferos com sua vulnerabilidade e importância ecológica, pois tem forte papel de dispersor de sementes que é fundamental para regeneração da floresta. A preservação dessa espécie atribui destaque para a Reserva Biológica de Poço das Antas, no distrito de Aldeia Velha, por realizar o trabalho de proteção e manejo, garantir a biodiversidade da região (Procópio de Oliveira Et al, 2008).

\section{1}

\section{Um Breve Histórico De Silva Jardim}

O primeiro histórico bibliográfico sobre Silva Jardim, antes chamado de Capivari, aconteceu no "Diccionario geographico, historico e descriptivo, do Imperio do Brazil” de J. C. R. Milliet de Saint-Adolphe, publicado em 1845, onde nas páginas 237 e 238 encontra- se:

Capivari. Nova villa e antiga freguesia da provincia do Rio de Janeiro, comarca de Cabo Frio, cabeça de collegio eleitoral. Uma capella edificada por Maria Rodrigues, no passado século, era a única igreja que se achava num vasto território situado entre a cordilheira dos Aimorés, e o rio Bacaxá, mas a povoação tendo-se augmentado, edificou-se largo tempo depois outra igreja da ivocação de N.S da Lapa, e o Bispo do Rio de Janeiro lhe conferio o título de freguesia por provisão do mez d' Outubro de 1810. Uma lei provineial de 8 de maio de 1841 elevou esta freguesia á categoria de villa. Seu districto, desmembrado da cidade de Cabo frio, se compõe no território de fraguezia, e do das aldeas velhas e novas d' Ipuca, e se extende ao norte pela cordilheira dos Aimorés, até a da Nova Friburgo; a oeste, confronta com os territórios das freguesias de Trindade e Rio Bonito; ao sul, o rio Bracacaxá o separa do districto da cidade de Cabo- Frio; e a leste, fica contiguo com o da villa de Macahé. Em 1835 apenas se contavam 2,000 almas neste distrito, mas actualmente passarão de 3,000. A indústria principal da gente d'elle, além da agricultação dos gencros do paiz, consiste no corte e preparação de madeiras de construcçao; Taboado, etc., que vão por agua elos ribeiros e canaes, até o rio de São- João, d' onde são transportados em barcos para o Rio de Janeiro. (Saint- Adolphe, 1845, pág. 237 e 238) 
Porém, o surgimento de Silva Jardim vai anteceder ao seu título de freguesia. Em "Como era verde o meu vale..." um estudo arqueológico de Paulo Seda em Gaviões, distrito de Silva Jardim, publicado em 2013, deixa claro como os vestígios do mundo rural do século XIX continha muitos marcos não relatados de uma história rica e densa do município (Figura 6).

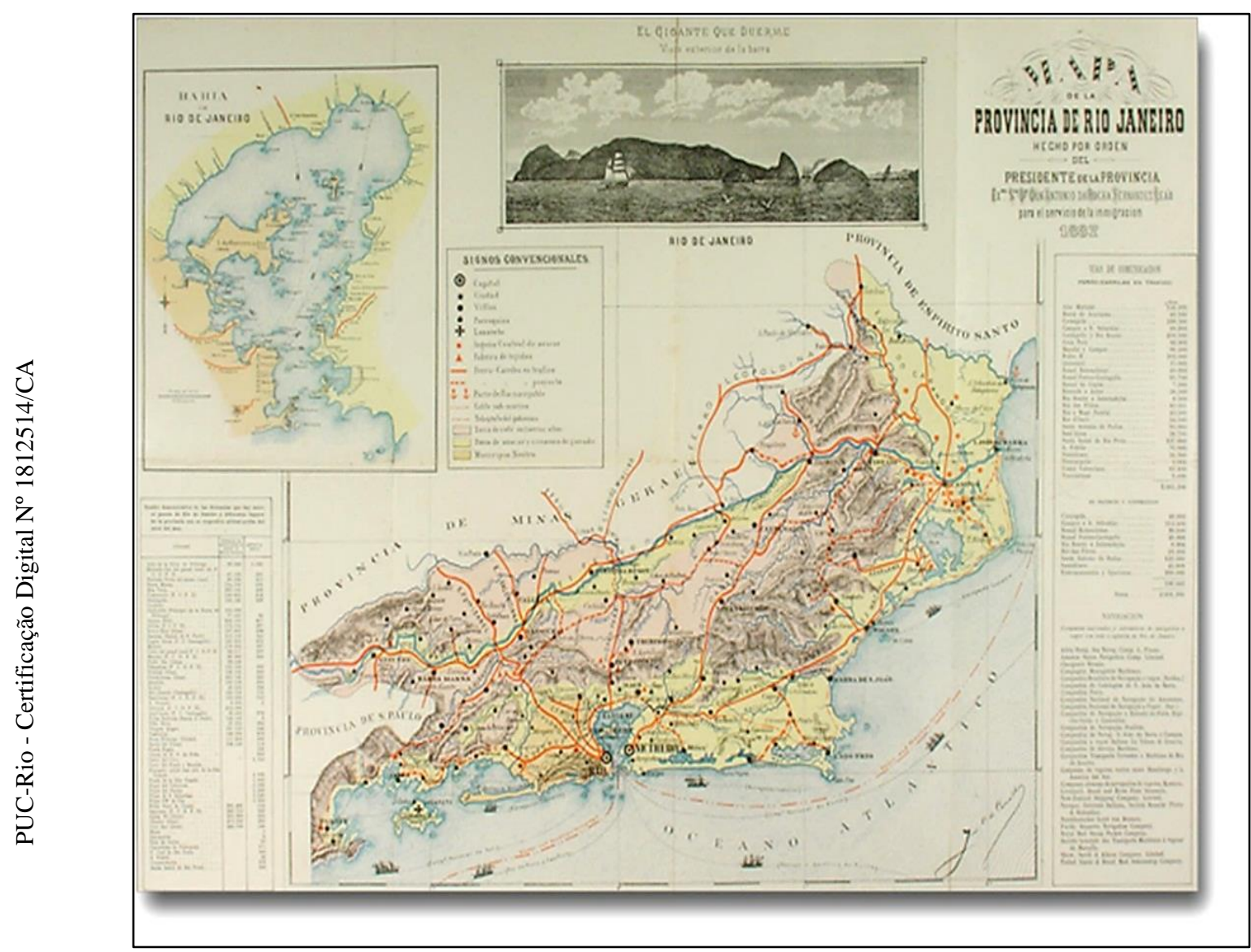

Figura 6. Carvalho, J. C. Mapa de la Província de Rio de Janeiro. Gravura colorida com a legenda" Mapa de la Provincia de Rio de Janeiro hecho por ordem del Presidente de la exmo. Sr. Don Antonio da Rocha Fernandes Leão para el servicio de la inmigracion". $53 \mathrm{x}$ 74

Na primeira metade do século XVIII foi fundada uma ermida juntamente com um aldeamento de índios Guarulhos sob a condução do capuchinho italiano Frei Francisco Maria de Todi. Com a degradação da ermida, se optou por buscar outro local para sua construção e assentar o aldeamento. O local escolhido foi às margens do rio São João. Anos depois a administração da capela construída e do aldeamento 
fica na responsabilidade dos padres seculares, isso provoca a desconcentração dos índios, em consequência o fim do aldeamento. Isso levou ao repartimento e distribuição dessas terras para colonos que as requeriam (Seda, 2013).

Na segunda metade do século XVIII, às margens da Lagoa de Juturnaíba, foi erguida a capela de N.S. da Lapa de Capivari. Ainda nesse período, na fazenda de Manoel Azevedo e D. Maria Rodrigues, foi fundada uma capela dedicada a Santana. Esse teria sido o marco da ocupação do povoado de Capivari, para alguns. Os moradores desse povoado foram conquistando os montantes do rio São João, atraídos pela abundância de madeiras-de-lei e pela fertilidade do solo adequado ao desenvolvimento da agricultura. As incursões rio acima deram origem a novos povoados, entre eles: Capivari, Poço das Antas, Correntezas e Gaviões. O município e a cidade de Silva Jardim tiveram origem em um destes novos povoados, o de Capivari (Seda, 2013).

Em 1828, no Regime das Câmaras Municipais, indica o crescimento de Capivari, seus moradores buscaram com efervescência a categoria de Freguesia para o povoado, assim, levando a maior autonomia. Então, em 9 de outubro de 1801 foi fundada a Freguesia de Nossa Senhora da Lapa de Capivari (Seda, 2013).

A produção agrícola da região, principalmente a produção de cana-de açúcar, café e cereais, trouxe crescimento e desenvolvimento (Seda, 2013). Assim, pela Lei $\mathrm{n}^{\mathrm{o}} 239$, em 8 de maio de 1841, Nossa Senhora da Lapa de Capivari ganha o título de Vila. Em 6 de janeiro de 1843, foi construído uma Câmara, cadeia pública e cemitério nas terras doadas por Luiz Gomes. Nessa época, a localidade já tinha atingido um grau bem elevado de comércio e era bastante populosa, vivendo praticamente da lavoura, onde o braço escravo era fundamental. Possuía bons estabelecimentos comerciais, botica e movimento no porto construído no rio São João. Além da lavoura, dedicava-se à exportação de madeira e minérios, atividades que forneciam bons lucros (Abreu, 1994).

Em 1881, os trilhos da Estrada de Ferro Leopoldina chegaram à região de Silva Jardim (Figura 7) aumentando o movimento e as possibilidades de crescimento, além do escoamento da produção que antes era realizado apenas de forma fluvial por cabotagem ao longo do rio São João (Abreu, 1994). 
tarde foi construída a barragem da Lagoa de Juturnaíba, que abastece de água vários municípios, e executado o saneamento do Rio São João (Peixoto e Costa Junior, 2004).

\section{2 \\ Caracterização ambiental}

De acordo com Bergallo (2009), a Região da Baixada Litorânea é caracterizada por colinas, maciços costeiros e baixadas. Nessas últimas, observamse diversas formações, tais como planícies aluviais em muitos trechos de brejo. A cobertura vegetal original do território dessa região era constituída, principalmente, por formações típicas das áreas aluviais com vegetação herbácea, comuns na Mata Atlântica.

O município de Silva Jardim apresenta um quadro geomorfológico complexo e diferenciado em razão da morfogênese. As diferentes combinações morfoestruturais e morfológicas respondem pela existência de regiões ambientais distintas. Neste contexto observa-se a existência dos domínios: Escarpas da Serra dos Órgãos, Colinas e Maciços Costeiros, e Planícies Costeiras (Coe, 2007).

$\mathrm{Na}$ serra do Mar são observadas escarpas abruptas, originadas por falhas escalonadas. A topografia do maciço Litorâneo é constituída por um planalto dissecado, de relevo diversificado. A baixada é composta por pequenas elevações onde estão situados os maiores trechos dos rios que formam a bacia do Rio São João e onde estão depositadas as terras de maior fertilidade, formadas por aluviões trazidos pelos rios cujas cabeceiras encontram-se na serra do Mar e nos maciços do litoral. Observa-se ainda a presença de terras-baixas de difícil drenagem (Coe, 2007).

Os solos são caracterizados como de médio e elevado grau de intemperização, com reações ácida e levemente neutra, forte presença de ferro, mica, berilo e calcários, e ocorrência, ainda, de feldspato e quartzo na rocha de origem, materiais observados também no baixo curso do rio São João onde repousam sedimentos aluvianos e restingas marinhas (Coe, 2007).

A Bacia do Rio São João, onde se localiza o divisor de águas, a Serra do Mar, possui grande parte do seu território coberto por fragmentos e maciços florestais 
remanescentes da Mata Atlântica, além de abrigar importantes ecossistemas de água doce. Percorre uma distância de $150 \mathrm{~km}$ até desaguar no oceano Atlântico, em seu percurso a maior parte é ocupada por amplas planícies fluviomarinhas, sobre grande influência do mar, permitindo, assim, a penetração da cunha salina por vários quilômetros para o interior do Rio São João (Oliveira e Mello, 2007; Wasserman et al. 2008). O rio São João nasce na cota aproximada de 900 metros, no divisor entre suas águas e as do rio Macaé, e os afluentes principais são os rios Bacaxá e Capivari. Merecem ainda destaque na formação da bacia os rios Águas Claras, Aldeia Velha, Bananeiras, Crubixás, Maratuã, do Ouro, da Prata, Pilões, Pirineus, São Lourenço, Taquarussús e Vargem Grande (Oliveira e Mello, 2012; Wasserman et al. 2008).

Os solos são mais férteis nos vales formados pelos rios, que com sua planície realizam um fenômeno semelhante ao processo natural de inundação a que é submetido o rio Nilo, no Egito. As inundações regulares que ocorriam no período de chuva deixavam material orgânico responsável pelo fertilizante dos solos, criando boas áreas para plantação. Um dos corpos hídricos de maior destaque da região é a lagoa de Juturnaíba, situada em uma extensa planície conhecida no passado por baixada de Araruama (Wasserman et al. 2008).

Grande parte da região, principalmente na serra, é coberta pela Mata Atlântica e protegida pela Reserva da Biosfera da Mata Atlântica, homologada pela Organização das Nações Unidas para a Educação, a Ciência e a Cultura-UNESCO, em 1992 (MMA, 2010).

No plano Municipal de Conservação e Recuperação da Mata Atlântica, Silva Jardim mostra que os principais usos e cobertura do solo da região da Baixada Litorânea são os apresentados na Tabela III, abaixo:

Tabela 3. Caracterização de uso do solo na região da Baixada Litorânea.

Caracterização de uso do solo

\begin{tabular}{ll}
\hline Área Agrícola & Terra utilizada para produção de alimentos \\
\hline Área Inundável & $\begin{array}{l}\text { Terra que margeia rios e sujeitas e inundação } \\
\text { no período de cheia }\end{array}$ \\
\hline Afloramento Rochoso & $\begin{array}{l}\text { Área com alta declividade ou topo de morro e } \\
\text { vegetação composta de gramíneas e } \\
\text { pteridofilas }\end{array}$ \\
\hline
\end{tabular}




\begin{tabular}{|c|c|}
\hline Área urbana & $\begin{array}{l}\text { Compreendem áreas de uso intensivo, } \\
\text { estruturadas por edificações e sistema viário }\end{array}$ \\
\hline Campos de Altitude & $\begin{array}{l}\text { Vegetação típica dos ambientes montanos e } \\
\text { alto montano, com estrutura arbustiva }\end{array}$ \\
\hline Campos/ Pastagem & $\begin{array}{l}\text { Área destinada ao pastoreio do gado, formada } \\
\text { mediante plantio perenes. Solo coberto por } \\
\text { gramíneas }\end{array}$ \\
\hline Floresta Estacional & $\begin{array}{l}\text { Estrutura florestal com perda das folhas dos } \\
\text { estratos superiores durante a estação seca e fria }\end{array}$ \\
\hline Floresta Ombrófila & $\begin{array}{l}\text { Floresta que ocorre em ambientes sombreados } \\
\text { onde a umidade é alta e constante }\end{array}$ \\
\hline Mangue & $\begin{array}{l}\text { Ecossistema costeiro, de transição entre os } \\
\text { ambientes terrestres e marinhos }\end{array}$ \\
\hline Praia & Faixa de área na orla marítima \\
\hline Restinga & $\begin{array}{l}\text { Conjunto das comunidades vegetais, sob } \\
\text { influência marinha e Fúlvio-marinha }\end{array}$ \\
\hline Reflorestamento & Plantio de espécies florestais nativas e exóticas \\
\hline Rios e Lagos & Curso de água natural \\
\hline Salinas & Área destinada a produção de sal \\
\hline Solo Exposto & Solos degradados, não possui camada orgânica \\
\hline Vegetação em recuperação & $\begin{array}{l}\text { Vegetação secundária com predomínio de } \\
\text { espécies pioneiras, comum a fragmentos } \\
\text { florestais }\end{array}$ \\
\hline Vegetação de várzea & Vegetação de planícies inundáveis \\
\hline
\end{tabular}

Podemos visualizar a espacialização dos dados da tabela de cobertura e uso da região da Bacia do Rio São João na Figura 8. 


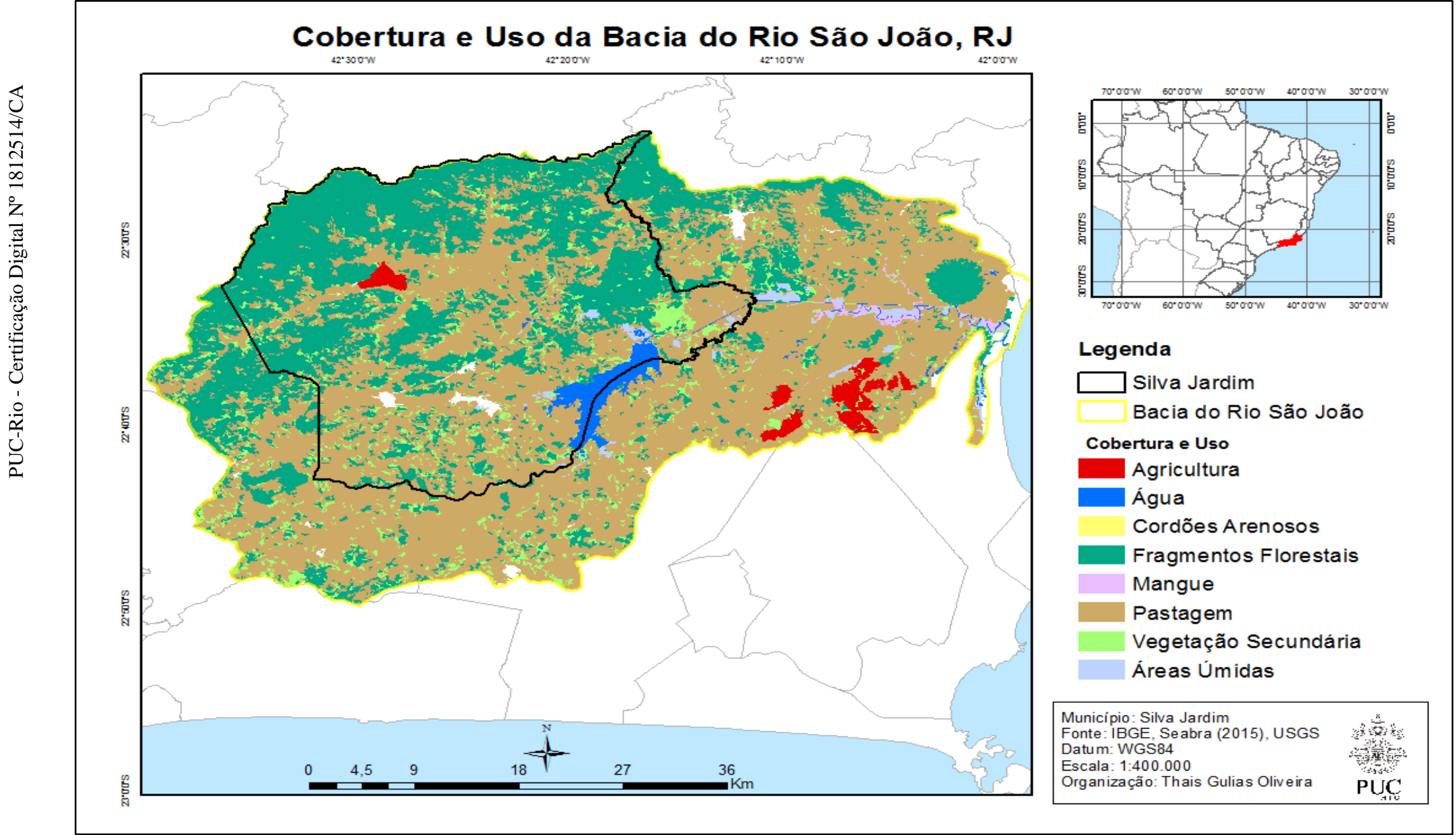

Figura 8. Mapa de cobertura e uso da Bacia do Rio São João, RJ. Fontes: Autora 
A vegetação da Região da Bacia do São João constitui-se por um conjunto de diferentes fragmentos, refletindo a inclinação e a orientação das encostas, a profundidade do solo e mesmo o tempo decorrido dos processos antrópicos de exploração vegetal. Há ainda tipos rasteiros de vegetação, que aparecem em tufos sobre as escarpas. Sendo possível encontrar exemplares de essências florestais que no passado faziam parte da cobertura vegetal nativa da região, entre elas o cedro (Cedrella spp.), o jequitibá-rosa (Cariniana sp.), sapucaia (Portulaca oleracea), tapinhoã (Ocotea odorifera), ipê (Tebebuia spp.), braúna (Melaoxylon brauna),vinhático (Planthymenia sp.) (MMA, 2012). Estruturas de grande porte que chamaram a atenção para a exploração e extração de madeira nessa região.

No território onde se localizam os remanescentes florestais da Mata Atlântica que cobrem grande parte do relevo e parte da baixada, nesse domínio, nos locais onde a vegetação ainda mantém condições originais, podem ser encontrados muitos grupos de mico-leão dourado (Leontopitecus rosalia), poucas e solitárias preguiçasde-coleira (Bradypus torquatus), além de muitas outras espécies de animais silvestres (MMA, 2012; Procópio de Oliveira Et al, 2008). A prova disso é que Silva Jardim possui o maior porcentual de vegetação natural conservada na região da Baixada Litorânea como pode se observar na Tabela IV do Plano Municipal de Conservação e Recuperação da Mata Atlântica de Silva Jardim de 2017, porém a amostragem é de 2014, essa mostra uma avaliação detalhada sobre a regeneração da Mata Atlântica.

O clima da região é classificado como tropical quente e úmido com temperaturas médias anuais entre 18 e 32 graus Celsius. O verão é quente, opressivo, com precipitação e de céu encoberto; o inverno é agradável, úmido e de céu quase sem nuvens. Tendo grande chamariz turístico nos meses de maio a setembro, por possuir um clima agradável. O total pluviométrico registrado de médio anual é de 1435,3 mm. Os meses mais chuvosos sendo janeiro, novembro e dezembro, com 662,2 mm, correspondendo a $46 \%$ da chuva anual. Os meses mais secos são junho, julho e agosto, com 122,2 mm correspondendo a 8,5\% da chuva anual (Santos, 2009). 
Capitulo 3. Identificação de análise dos processos históricos da fragmentação de Silva Jardim, RJ

Tabela 4. Porcentagem de Mata Atlântica em municípios abrangidos pela floresta.

Destaque para o município de Silva Jardim, RJ.

Porcentagem de Mata Atlântica em municípios abrangidos pela floresta (Lei da Mata Atlântica), ano-base 2014

\begin{tabular}{lllll}
\hline Municípios & Área municipal (ha) & Mata (ha) & Veg. Natural (há) & $\begin{array}{l}\text { \% de Veg. } \\
\text { Natural }\end{array}$ \\
\hline Araruama & 63.405 & 1,744 & 2.384 & 4 \\
\hline $\begin{array}{l}\text { Armação dos } \\
\text { Búzios }\end{array}$ & 7.093 & 413 & 1.547 & 22 \\
\hline Arraial do Cabo & 15.396 & 163 & 974 & 6 \\
\hline Cabo Frio & 40.275 & 1.162 & 3.198 & 8 \\
\hline $\begin{array}{l}\text { Casimiro de } \\
\text { Abreu }\end{array}$ & 46.226 & 14.059 & 14.200 & 31 \\
\hline $\begin{array}{l}\text { Iguaba Grande } \\
\text { Maricá }\end{array}$ & 5.162 & 51 & 98 & 2 \\
\hline Rio Bonito & 36.365 & 7.637 & 8.006 & 22 \\
\hline Rio das Ostras & 23.154 & 6.877 & 6.877 & 15 \\
\hline $\begin{array}{l}\text { São Pedro da } \\
\text { Aldeia }\end{array}$ & 34.154 & 3.172 & 3.382 & 15 \\
\hline Saquarema & 35.612 & 778 & 2.1553 & 6 \\
\hline Silva Jardim & $\mathbf{9 3 . 8 4 6}$ & 4.653 & 5.862 & 16 \\
\hline & & $\mathbf{3 1 . 5 1 7}$ & $\mathbf{3 1 . 7 6 9}$ & $\mathbf{3 4}$ \\
\hline
\end{tabular}

Fonte: Plano Municipal de Conservação e Recuperação da Mata Atlântica de Silva Jardim. Rio de Janeiro, 2017. 


\section{Materiais e métodos}

A etapa inicial foi pautada no levantamento bibliográfico para estabelecer uma abordagem conceitual capaz de melhor entender os objetos de estudo e metodologias. Esses levantamentos foram feitos com ajuda de publicações técnicas e acadêmicas.

A etapa seguinte é a proposta metodológica que responde os objetivos de Espacialização da Lei de Proteção da Vegetação Nativa- LPVN, classificando e avaliando o potencial dos fragmentos para conectividade, assim criando corredores ecológicos capazes de aumentar a capacidade de conservação ambiental do Município de Silva Jardim dentro da bacia do Rio São João.

A seguir, apresentam-se os materiais utilizados e etapas metodológicas que consistem: na escolha dos dados, a escolha dos softwares usados, a definição da área de estudo, a análise dos dados escolhidos, a espacialização do Lei de Proteção da Vegetação Nativa e a análise dos fragmentos potenciais.

\section{1}

\section{Materiais}

\subsection{1}

Dados

Para o desenvolvimento desse estudo, utilizamos:

Tabela 5. Dados selecionados para realização da pesquisa

\begin{tabular}{|c|c|c|c|c|c|}
\hline Nome & Tipo & Escala & SGR & Ano & Fonte \\
\hline $\begin{array}{l}\text { Áreas de } \\
\text { proteção } \\
\text { ambiental e } \\
\text { reservas legais } \\
\text { da Bacia do Rio } \\
\text { São João }\end{array}$ & vetor & $1: 250.000$ & $\begin{array}{l}\text { SIRGAS } \\
2000\end{array}$ & 2010 & $\begin{array}{l}\text { Vinicius da } \\
\text { Silva Seabra } \\
(\text { FFP/UERJ) }\end{array}$ \\
\hline $\begin{array}{l}\text { Sub-bacias do } \\
\text { municio de Silva } \\
\text { Jardim }\end{array}$ & vetor & $1: 250.000$ & $\begin{array}{l}\text { SIRGAS } \\
2000\end{array}$ & 2010 & $\begin{array}{l}\text { Vinicius da } \\
\text { Silva Seabra } \\
\text { (FFP/UERJ) }\end{array}$ \\
\hline $\begin{array}{l}\text { Curvas de nível } \\
\text { da Bacia do Rio } \\
\text { São João }\end{array}$ & vetor & $1: 250.000$ & $\begin{array}{l}\text { SIRGAS } \\
2000\end{array}$ & 2010 & $\begin{array}{l}\text { Vinicius da } \\
\text { Silva Seabra } \\
\text { (FFP/UERJ) }\end{array}$ \\
\hline
\end{tabular}




\begin{tabular}{|c|c|c|c|c|c|}
\hline $\begin{array}{l}\text { Hidrografia do } \\
\text { da Bacia do Rio } \\
\text { São João }\end{array}$ & vetor & $1: 250.000$ & $\begin{array}{l}\text { SIRGAS } \\
2000\end{array}$ & 2010 & $\begin{array}{l}\text { Vinicius da } \\
\text { Silva Seabra } \\
\text { (FFP/UERJ) }\end{array}$ \\
\hline $\begin{array}{l}\text { Limite } \\
\text { geográficos da } \\
\text { Bacia do Rio } \\
\text { São João }\end{array}$ & vetor & $1: 50.000$ & SAD69 & & $\begin{array}{l}\text { Vinicius da } \\
\text { Silva Seabra } \\
\text { (FFP/UERJ) }\end{array}$ \\
\hline $\begin{array}{l}\text { Base } \\
\text { Cartográfica } \\
\text { Contínua do } \\
\text { Brasil }\end{array}$ & vetor & $1: 250.000$ & $\begin{array}{l}\text { SIRGAS } \\
2000\end{array}$ & 2017 & IBGE \\
\hline $\begin{array}{l}\text { Base } \\
\text { cartográfica do } \\
\text { Estado do Rio } \\
\text { de Janeiro }\end{array}$ & vetor & $1: 25.000$ & $\begin{array}{l}\text { SIRGAS } \\
2000\end{array}$ & 2018 & IBGE \\
\hline $\begin{array}{l}\text { Base } \\
\text { cartográfica do } \\
\text { Estado do Rio } \\
\text { de Janeiro em } \\
\text { propriedades } \\
\text { urbanas e rurais }\end{array}$ & vetor & $1: 25.000$ & $\begin{array}{l}\text { SIRGAS } \\
2000\end{array}$ & 2018 & IBGE \\
\hline $\begin{array}{l}\text { Base vetoriais } \\
\text { do CAR do } \\
\text { Município de } \\
\text { Silva Jardim }\end{array}$ & vetor & $1: 250.000$ & $\begin{array}{l}\text { SIRGAS } \\
2000\end{array}$ & 2019 & SICAR \\
\hline $\begin{array}{l}\text { Uso e Cobertura } \\
\text { do Solo do } \\
\text { município de } \\
\text { Silva Jardim }\end{array}$ & vetor & $1: 25.000$ & $\begin{array}{l}\text { SIRGAS } \\
2000\end{array}$ & 2013 & FBDS \\
\hline $\begin{array}{l}\text { Hidrografia do } \\
\text { município de } \\
\text { Silva Jardim }\end{array}$ & vetor & $1: 25.000$ & $\begin{array}{l}\text { SIRGAS } \\
2000\end{array}$ & 2013 & FBDS \\
\hline $\begin{array}{l}\text { Imagens de } \\
\text { satélite Landsat } \\
8\end{array}$ & matriz & $\begin{array}{l}30 \text { metros de } \\
\text { resolução } \\
\text { espectral }\end{array}$ & $\begin{array}{l}\text { SIRGAS } \\
2000\end{array}$ & 2018 & USGS \\
\hline
\end{tabular}

Fonte: Autora

\subsection{2}

Softwares utilizados

Foi definido que o software de geoprocessamento, processamento de dados e imagens utilizado nesse estudo seria o SIG ArcGIS 10.6.6, pois ele tem capacidade de realizar procedimentos computacionais de análises geoespaciais juntamente com outros softwares e hardware, assim otimizando várias tomadas de decisões. Nesse ambiente é capaz de manipular dados vetoriais, ou seja, um par de coordenadas expressados em pontos, linhas ou polígonos, ou raster que são uma matriz formada por pixels que são associados a cores formando uma imagem. Os dados vetoriais são normalmente arquivos ESRI shapefile, KML do Google Earth e desenhos DXF/DWG do AutoCAD e os rasters são arquivos de imagem TIF, JPG, PNG (Menezes, 2013). 
Para as análises dos fragmentos optamos pelo uso do script V- Late 2.0 que é uma extensão de ferramentas de análise de paisagem baseada em vetores do SIG ArcGIS 10.6.6. A escolha dele é devido à sua capacidade de quantificar a fragmentação da paisagem, fornecendo valores para as áreas e a distribuição espacial dos fragmentos dentro da paisagem. Como já abordado, ele tem a capacidade de seleção das métricas mais comuns para cobrir a investigação ecológica e estruturais relacionadas a paisagem. (Lang, 2003)

Para traçar a relação das variáveis levantadas pela espacialização e pelos resultados das métricas de paisagem usou-se o RStudio. O RStudio se trata de um software livre e colaborativo, que utiliza a linguagem $\mathrm{R}$ para programar gráficos e cálculos estatísticos (R Core Team, 2015).

\section{2 \\ Metodologia}

Se construiu uma análise histórica de ocupação, uso do solo e geomorfológica sobre a área de estudo a fim de entender os processos que levaram a segmentação dessa paisagem com uso de dados bibliográficos e da legislação pertinente a essa região.

Com base nas bibliografias lidas e que usamos para compor a revisão bibliográfica foram selecionados os dados listados no item 4.1.1. Eles foram obtidos através de sites federais de intuições de pesquisas, ONG's ou solicitados a pesquisadores que realizam estudos no município de Silva Jardim. Chegando assim as melhores opções segundo as bibliografias para esse trabalho.

\section{2 .1}

\section{Espacialização da Lei de Proteção da Vegetação Nativa}

Foram levantados todos os parâmetros da Lei de Proteção da Vegetação Nativa em área de APP e RL incidentes na área de estudo. Com base nas interpretações destes parâmetros, foram reunidos os dados geoespaciais para realizar a espacialização da LPVN a partir de ferramentas do SIG ArcGIS, como é apresentado na tabela abaixo. 
Tabela 6. Metodologia e dados aplicados na espacialização das LPVN.

\begin{tabular}{|c|c|c|c|}
\hline \multicolumn{2}{|c|}{$\begin{array}{c}\text { Lei de Proteção da Vegetação } \\
\text { Nativa (LPVN)/ (Lei no } 12.651 / 12)\end{array}$} & Dados & Ferramentas \\
\hline APP de nascente & Raio de $50 \mathrm{~m}$ & $\begin{array}{l}\text { Base vetorial da } \\
\text { FBDS de Hidrografia } \\
\text { do município de } \\
\text { Silva Jardim }\end{array}$ & $\begin{array}{l}\text { Polígono com a } \\
\text { metragem estipulada } \\
\text { pela legislação - } \\
\text { Buffer }\end{array}$ \\
\hline $\begin{array}{l}\text { APP de cursos } \\
\text { d'água }\end{array}$ & $\begin{array}{l}30 \mathrm{~m} \text { na faixa marginal } \\
\text { de cursos } \\
\text { d'água com largura até } \\
10 \mathrm{~m} ; 50 \mathrm{~m} \text { na faixa } \\
\text { marginal de cursos } \\
\text { d'água com largura de } \\
10 \text { a } 50 \mathrm{~m} \text {; } 100 \mathrm{~m} \text { na } \\
\text { faixa marginal de cursos } \\
\text { d'água com largura de } \\
50 \text { a } 200 \mathrm{~m}\end{array}$ & & $\begin{array}{l}\text { Polígono com a } \\
\text { metragem estipulada } \\
\text { pela legislação - } \\
\text { Buffer }\end{array}$ \\
\hline $\begin{array}{l}\text { APP de lagos e } \\
\text { lagoas } \\
\text { naturais }\end{array}$ & $\begin{array}{l}50 \mathrm{~m} \text { na faixa marginal } \\
\text { de lagos e lagoas de } 1 \mathrm{a} \\
20 \text { ha (inseridos em } \\
\text { zona rural); } 100 \mathrm{~m} \text { na } \\
\text { faixa marginal de lagos } \\
\text { e lagoas maiores que } 20 \\
\text { ha (inseridos em zona } \\
\text { rural); } 30 \mathrm{~m} \text { na faixa } \\
\text { marginal dos lagos e } \\
\text { lagoas (inseridos em } \\
\text { área urbana) }\end{array}$ & & $\begin{array}{l}\text { Polígono com a } \\
\text { metragem estipulada } \\
\text { pela legislação - } \\
\text { Buffer }\end{array}$ \\
\hline $\begin{array}{ll}\text { APP } & \text { de } \\
\text { brejo/veredas }\end{array}$ & $\begin{array}{l}50 \mathrm{~m} \text { na faixa marginal a } \\
\text { partir do espaço } \\
\text { permanentemente } \\
\text { brejoso e encharcado }\end{array}$ & & $\begin{array}{l}\text { Polígono com a } \\
\text { metragem estipulada } \\
\text { pela legislação - } \\
\text { Buffer }\end{array}$ \\
\hline $\begin{array}{ll}\text { APP } & \text { de } \\
\text { reservatórios de } \\
\text { água artificial }\end{array}$ & $\begin{array}{l}\text { Faixa conforme } \\
\text { definiçãa da licença } \\
\text { ambiental de } \\
\text { empreendimente }\end{array}$ & & \\
\hline 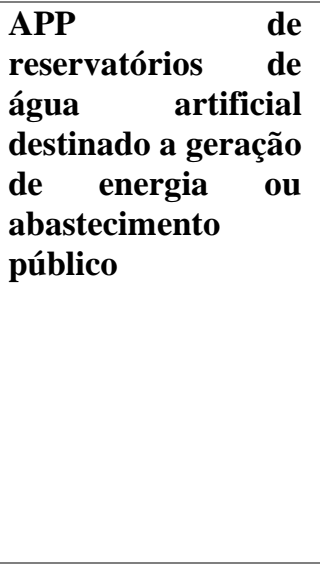 & $\begin{array}{l}\text { Faixa mínima de } 30 \mathrm{~m} \text { e } \\
\text { máximo de } \\
100 \mathrm{~m} \text { (inseridos em } \\
\text { área rural); Faixa } \\
\text { mínima de } 15 \mathrm{~m} \text { e } \\
\text { máximo de } 30 \mathrm{~m} \\
\text { (inseridos em área } \\
\text { urbana); Đistância entre } \\
\text { e máxime operative } \\
\text { normale a cota máxima } \\
\text { maximorum (registrado, } \\
\text { comautorização-ou } \\
\text { contrato de concessão } \\
\text { assinado antes de 2001) }\end{array}$ & & $\begin{array}{l}\text { Polígono com a } \\
\text { metragem estipulada } \\
\text { pela legislação - } \\
\text { Buffer }\end{array}$ \\
\hline $\begin{array}{l}\text { APP de Topo de } \\
\text { Morro }\end{array}$ & $\begin{array}{l}1 / 3 \text { maior de morros e } \\
\text { montanhas, com altura } \\
\text { maior que } 100 \mathrm{~m} \mathrm{e} \\
\text { declividade maior que } \\
25^{\circ}\end{array}$ & $\begin{array}{l}\text { Base vetorial das } \\
\text { Curvas de nível da } \\
\text { Bacia do Rio São } \\
\text { João, disponibilizada } \\
\text { pelo Prof. Seabra. }\end{array}$ & $\begin{array}{l}\text { MDT (modelo digital } \\
\text { do terreno)- TIN. } \\
\text { Mapa de declividade- } \\
\text { Slope. } \\
\text { Reclassificação da } \\
\text { declividade de } \\
\text { interesse- Reclassify }\end{array}$ \\
\hline $\begin{array}{l}\text { APP de Linha de } \\
\text { Cumeada }\end{array}$ & $\begin{array}{l}1 / 3 \text { maior da altura em } \\
\text { relação a base, do pico }\end{array}$ & $\begin{array}{l}\text { Base vetorial das } \\
\text { Curvas de nível da }\end{array}$ & $\begin{array}{l}\text { MDT (modelo digital } \\
\text { do terreno)- TIN. }\end{array}$ \\
\hline
\end{tabular}




\begin{tabular}{|c|c|c|c|}
\hline & $\begin{array}{l}\text { mais baixo da cumeada } \\
\text { distantes em pelo menos } \\
1000 \mathrm{~m}\end{array}$ & $\begin{array}{l}\text { Bacia do Rio São } \\
\text { João, disponibilizada } \\
\text { pelo Prof. Seabra. }\end{array}$ & $\begin{array}{l}\text { Mapa de declividade- } \\
\text { Slope. } \\
\text { Reclassificação da } \\
\text { declividade de } \\
\text { interesse- Reclassify }\end{array}$ \\
\hline APP de encostas & $\begin{array}{l}\text { Encostas ou partes } \\
\text { destas com declividade } \\
\text { superior a } 45^{\circ} \\
\text { (equivalente a } 100 \% \text { ) na } \\
\text { linha de maior declive }\end{array}$ & $\begin{array}{l}\text { Base vetorial das } \\
\text { Curvas de nível da } \\
\text { Bacia do Rio São } \\
\text { João, disponibilizada } \\
\text { pelo Prof. Seabra. }\end{array}$ & $\begin{array}{l}\text { MDT (modelo digital } \\
\text { do terreno)- TIN. } \\
\text { Mapa de declividade- } \\
\text { Slope. } \\
\text { Reclassificação da } \\
\text { declividade de } \\
\text { interesse- Reclassify }\end{array}$ \\
\hline Reserva legal & $\begin{array}{l}20 \% \text { da área do imóvel } \\
\text { rural }\end{array}$ & $\begin{array}{l}\text { Base vetoriais do } \\
\text { CAR para Reserva } \\
\text { Legal e Área de } \\
\text { Imóveis. }\end{array}$ & \\
\hline
\end{tabular}

Fonte: Adaptação da autora sobre a fonte Issi et. al 2018.

\section{2 .2}

\section{Aplicação das métricas de paisagem}

A partir da base vetorial de uso e cobertura da FBDS (2013), foi isolada a classe Formação Florestal, criando um shapefile com intuito de não haver uma leitura errônea de classes. A Classe Formação Florestal estava toda agrupada em uma única camada, então foi aplicado a ferramenta Multipart to Singlepart, para se obter o número de fragmentos. Para gerar a relação entre eles, o formato e o grau de conectividade, foram aplicadas as métricas de ecologia da paisagem selecionadas no V-Late. Sendo elas: área, densidade e tamanho, borda, forma, proximidade e área core. Elas foram escolhidas com base na leitura bibliográfico do trabalho de McGarigal e Marks (1994) e Lang (2003), sendo as mais coerentes para o êxito dos objetivos dessa pesquisa.

Por meio das métricas de densidade e tamanho, nota-se o número de manchas, tamanho médio das manchas e o desvio padrão das manchas. Com essas métricas foi possível entender o grau da diversidade.

Para melhor entendimento da paisagem, devido ao grande quantitativo de polígonos, foi realizado a segmentação da paisagem em classes de tamanho, através da ferramenta Select by Atributes.

Ao realizar as métricas de área central, definiu-se a distância de 100 metros da borda, com base na bibliografia para deslocamento de pequenos mamíferos (Crouzeilles, 2010). Desse modo, foram alcançados valores de área central total, área central média, número de manchas que apresentam área central, porcentagem total de áreas nucleares. 
Conhecendo os valores das métricas e tendo a segmentação da paisagem por classificação de tamanho dos fragmentos, foi realizada a união por meio da ferramenta Union de todos os shapefiles de áreas de APP e de Reserva Legal, assumindo que todas as áreas eram cobertas por vegetação, em seguida o recorte desse shapefile para cada classe de tamanho dos fragmentos através da ferramenta Clip. Em seguida, foi calculado por meio da ferramenta Area/Perimeter disponibilizada no V-Late o total da área protegida em cada classe.

\section{2 .3}

\section{Matriz de correlação}

Com objetivo de traçar uma correlação e retirar as redundâncias entre as múltiplas variáveis geradas pelas métricas de paisagem mais a espacialização da Lei de Proteção a Vegetação Nativa, se optou por gerar uma matriz de correlação no RStudio. Através do código:

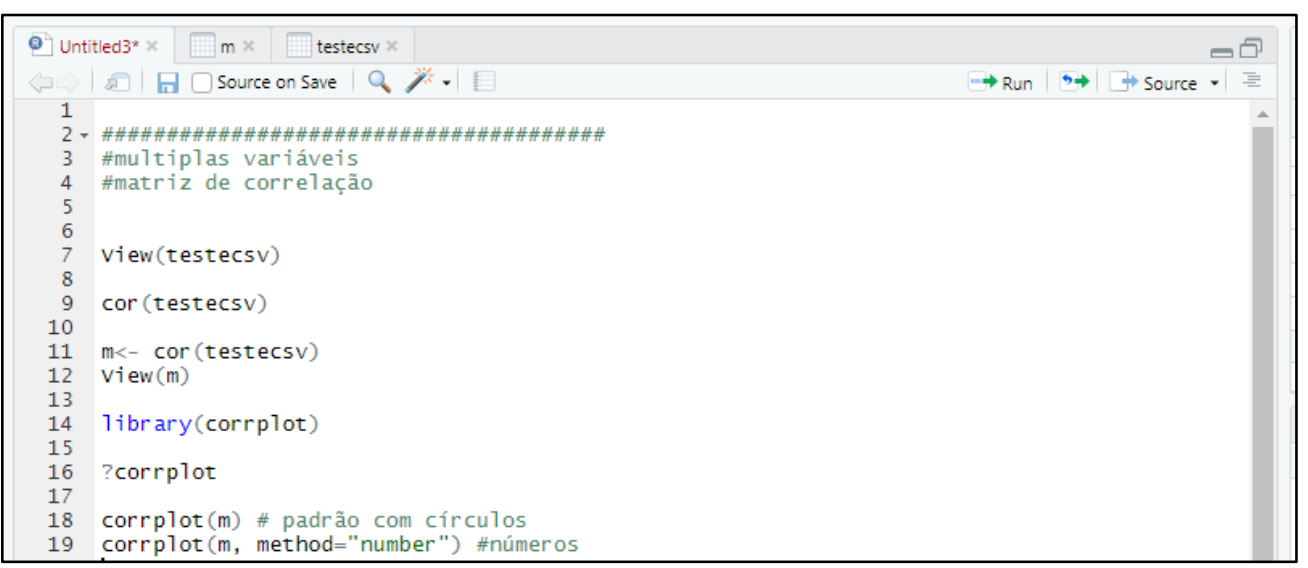

Figura 9. Código utilizado para gerar a matriz.

Fonte: Autora 
Onde testecsv é a tabela que se encontra os dados extraídos das métricas de paisagem gerados pelo V-Late, como vemos abaixo:

\begin{tabular}{|c|c|c|c|c|c|c|c|c|c|c|c|c|}
\hline (8) Untitled3* X & $m$ & tes & stecsv $\times$ & & & & & & & & & $=\square$ \\
\hline उद्व | & $\nabla$ Filter & & & & & & & & & c & 2 & \\
\hline$\Delta$ & CA & $\hat{*}$ & NP & MPS & PSSD & TE & ED & MSI & MNN & TCA & Area_app & $\Rightarrow$ \\
\hline $1(0-1 \mathrm{ha})$ & 306.3 & 0.33 & 724 & 0.423 & 2594.93 & 240709.5 & 785.67 & 1.721 & 0.0006 & 0.0 & 138 & \\
\hline $2(1-10 \mathrm{ha})$ & 1540.8 & 1.64 & 511 & 30.100 & 20215.22 & 526213.0 & 341.52 & 1.732 & 0.0030 & 5.1 & 638 & \\
\hline $3(10-50$ ha $)$ & 2540.4 & 2.71 & 116 & 21.900 & 113897.58 & 402556.9 & 158.46 & 2.125 & 0.0290 & 317.6 & 1120 & \\
\hline $4(50-100 \mathrm{ha})$ & 1623.5 & 1.73 & 26 & 62.400 & 106709.49 & 204120.2 & 125.72 & 2.793 & 0.0018 & 361.0 & 729 & \\
\hline $5(100-500 \mathrm{ha})$ & 34635.8 & 36.91 & 25 & 1385.400 & 41122754.97 & 2072161.1 & 59.83 & 5.528 & 8.9000 & 20063.1 & 13273 & \\
\hline
\end{tabular}

Figura 10. Tabela aberta no RStudio com os dados gerados no V-Late e na espacialização do LPVN.

Fonte: Autora

Dando sequência ao código foi aplicado a função $\operatorname{cor}($ ) que gerou uma matriz de correlações entre as variáveis da tabela selecionada, passando a se chamar $m$. A correlação de Pearson é um padrão dentro do programa. Pearson mede o grau de correlação de dados quantitativos contínuos. Pela fórmula, temos a correlação de uma variável entre -1 e 1 e que lemos como, quanto mais a variável estiver próxima a 1 ou -1 mais forte sua relação positiva ou negativa (Rocha, 2018). 


\begin{tabular}{|c|c|c|c|c|c|c|c|c|}
\hline Console & Jobs $x$ & & & & & & & $=\square$ \\
\hline \multicolumn{9}{|l|}{$\sim / \Leftrightarrow$} \\
\hline & CA & PP & NP & MPS & PSSD & TE & ED & $\boldsymbol{A}$ \\
\hline CA & 1.0000000 & 1.0000000 & -0.4851876 & 0.9987515 & 0.9986804 & 0.9886372 & -0.4880595 & \\
\hline PP & 1.0000000 & 1.0000000 & -0.4851683 & 0.9987497 & 0.9986819 & 0.9886277 & -0.4880049 & \\
\hline NP & -0.4851876 & -0.4851683 & 1.0000000 & -0.4727273 & -0.4499966 & -0.4191851 & 0.9439708 & \\
\hline MPS & 0.9987515 & 0.9987497 & -0.4727273 & 1.0000000 & 0.9993857 & 0.9846227 & -0.4715955 & \\
\hline PSSD & 0.9986804 & 0.9986819 & -0.4499966 & 0.9993857 & 1.0000000 & 0.9862183 & -0.4479597 & \\
\hline TE & 0.9886372 & 0.9886277 & -0.4191851 & 0.9846227 & 0.9862183 & 1.0000000 & -0.4683772 & \\
\hline ED & -0.4880595 & -0.4880049 & 0.9439708 & -0.4715955 & -0.4479597 & -0.4683772 & 1.0000000 & \\
\hline MSI & 0.9664529 & 0.9664485 & -0.6424457 & 0.9700010 & 0.9626341 & 0.9242182 & -0.6005164 & \\
\hline MNN & 0.9986874 & 0.9986891 & -0.4488972 & 0.9993073 & 0.9999969 & 0.9864557 & -0.4470976 & \\
\hline TCA & 0.9990926 & 0.9990943 & -0.4639758 & 0.9996099 & 0.9998665 & 0.9850300 & -0.4595199 & \\
\hline \multirow[t]{2}{*}{ Area_app } & 0.9999593 & 0.9999594 & -0.4923622 & 0.9984274 & 0.9982226 & 0.9882045 & -0.4947706 & \\
\hline & MSI & MNN & TCA & Area_app & & & & \\
\hline CA & 0.9664529 & 0.9986874 & 0.9990926 & 0.9999593 & & & & \\
\hline PP & 0.9664485 & 0.9986891 & 0.9990943 & 0.9999594 & & & & \\
\hline NP & -0.6424457 & -0.4488972 & -0.4639758 & -0.4923622 & & & & \\
\hline MPS & 0.9700010 & 0.9993073 & 0.9996099 & 0.9984274 & & & & \\
\hline PSSD & 0.9626341 & 0.9999969 & 0.9998665 & 0.9982226 & & & & \\
\hline TE & 0.9242182 & 0.9864557 & 0.9850300 & 0.9882045 & & & & \\
\hline ED & -0.6005164 & -0.4470976 & -0.4595199 & -0.4947706 & & & & \\
\hline MSI & 1.0000000 & 0.9620705 & 0.9664616 & 0.9675393 & & & & \\
\hline MNN & 0.9620705 & 1.0000000 & 0.9998433 & 0.9982270 & & & & \\
\hline TCA & 0.9664616 & 0.9998433 & 1.0000000 & 0.9987664 & & & & \\
\hline Area_app & 0.9675393 & 0.9982270 & 0.9987664 & 1.0000000 & & & & $\checkmark$ \\
\hline
\end{tabular}

Figura 11. Matriz de correlação gerada no RStudio em ordem numérica.

Fonte: Autora

Em seguida foi aplicado o pacote corrplot que segundo Wei (2017) é usado para exibição de gráficos de matrizes de correlação, além de conter alguns algoritmos que reordenam a matriz. Por exemplo, a exibição da matriz com círculo$\operatorname{corrplot}(m)$ e números- $\operatorname{corrplot}(m$, method="number" $)$.

Na página seguinte é possível ver o fluxograma da metodologia aplicada a essa pesquisa. 


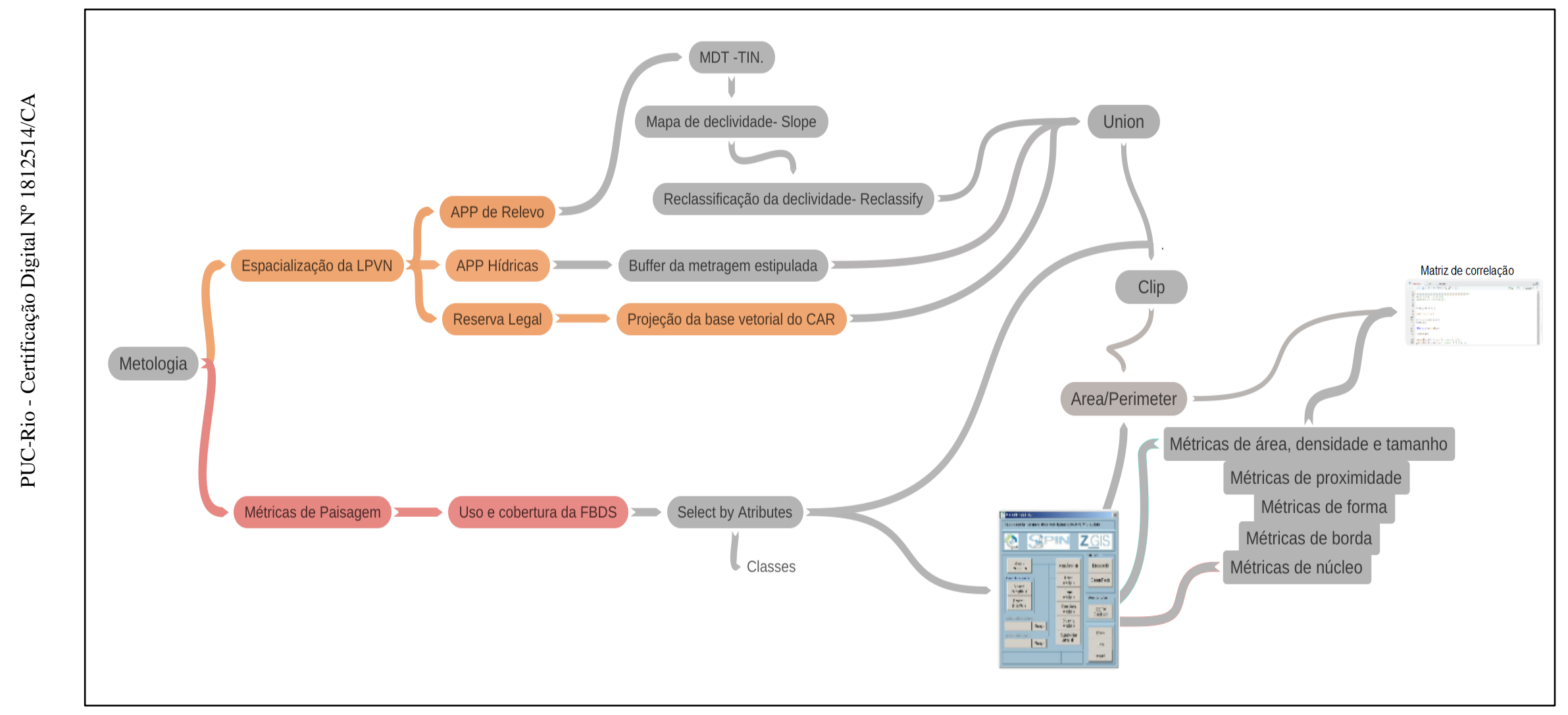

Figura 12 Fluxograma da metodologia

Fonte: Autora 


\section{Resultados e discussão}

Ao analisar os processos históricos de fragmentação de Silva Jardim no Rio de Janeiro, chegamos nos resultados apontados abaixo.

\section{1 Processo de Fragmentação na Bacia do Rio São João em Silva Jardim}

Todo o crescimento e interesse por Silva Jardim, antiga Capivari, ocorre pela possível exploração de seus recursos naturais, pois o estado do Rio de Janeiro está inserido em sua totalidade no bioma de Mata Atlântica, sendo uma zona de alta diversidade de fauna e flora, além de ricos recursos hídricos.

Segundo Dean em Ferro e Fogo, 2004, a história da Mata Atlântica é uma história de perdas porque em todo mundo ao longo dos anos a história das florestas está muito ligada à destruição em prol de enriquecimento ou ocupação. Afinal, para aos homens europeus, não havia um sentido de lugar naquelas sociedades compostas por inúmeras espécies de plantas e animais em contínua interação. Seus conhecimentos não possibilitavam viver em ambientes altamente hostis às suas necessidades como de fato é uma floresta tropical. Para permanecer lá, o homem branco precisava alterar aquela paisagem para sua melhor habitação e lucro. Assim, para viver na Mata Atlântica, os homens, necessariamente, precisaram destruí-la. Foi esse o caso dos portugueses que chegaram ao Continente Sul Americano no século XV.“(...) não parece errado dizer que, na América portuguesa, as pessoas viam a floresta basicamente como uma utilidade material" (Cabral, 2012).

No início do século XVI, e posteriormente, prosseguiu em escala inesperada a ocupação, exploração e, consequentemente, a alteração da vegetação natural nesse bioma. As causas são bem conhecidas: a extração de pau-brasil; a demanda de grossos lenhos para as numerosas e imensas caldeiras de derretimento da gordura de baleias; a procura de combustível lenhoso, em geral para uso da crescente população; o corte de madeiras-de-lei para construção naval e civil; a derrubada, queimada e limpeza de extensas áreas florestais para fins de pecuária, agricultura e, 
a ocupação de terrenos para o estabelecimento e desenvolvimento de povoados, vilas e cidades (Dean, 2004).

A Coroa portuguesa sempre demonstrou entender que o sucesso fiscal de sua colônia americana dependia do uso das suas abundantes matas. Quem não tem cão, caça com gato e a decepção inicial na procura de metais preciosos fez-la realizar que a floresta era tudo que ela tinha nessas terras distantes. (Cabral, 2012)

No século XVIII, se inicia a grande corrida para o interior em busca de riquezas. A mata nativa da região era abundante em madeiras-de-lei e o rio São João tornou-se fator importante no desbravamento e no desenvolvimento regional de Silva Jardim, além de facilitar o acesso rumo ao interior da baixada e o abastecimento, funcionava também como via de escoamento da produção agrícola e de lenha para os portos (Seda, 2013). Visto que na Europa ocorria a Revolução Industrial, que buscava matéria-prima para além de suas fronteiras, levando a Inglaterra a se voltar para outros mercados, favorecendo então o Brasil (Dean, 2004).

Uma vez devastada a floresta, o campo estava pronto para plantação que, pela fertilidade do solo, se adequou muito bem ao desenvolvimento da agricultura. Assim, a madeira cedeu lugar ao café e à cana-de-açúcar e o enriquecimento dos fazendeiros da região foi ainda mais relevante (Abreu, 1994).

Mas o que os agricultores prezavam, na verdade, eram as próprias árvores, ou melhor, a cinza proveniente de sua queima. Evidentemente, as árvores eram utilizadas também como madeira, mas apenas marginalmente em caráter comercial. Um dos mais famosos manuais agrícolas do século XIX, escrito por Luiz Peixoto de Lacerda Werneck (Barão de Pati do Alferes), aconselhava os fazendeiros a plantarem café em terras onde cresciam árvores como o jacarandá e outras excelentes espécies madeireiras típicas de floresta primaria. (Cabral, 2012)

No século XIX, os trilhos da Estrada de Ferro Leopoldina chegaram à região de Silva Jardim aumentando o movimento e as possibilidades de crescimento. A cultura do café era sua mais importante atividade agrícola, seguida pela cana-deaçúcar e cereais cultivados na baixada (Abreu, 1994).

A importância do seu porto e da Estrada de Ferro Central do Brasil potencializava o mercado muito acima da população da cidade, pois as mercadorias eram distribuídas através de cabotagem (...) Para o interior, os trilhos das estradas de ferro asseguravam o fornecimento de amplas regiões. (Levy, 1994) 
No entanto, esse desenvolvimento econômico não permaneceu mais do que um século. A extinção das matas, assim como a exaustão dos solos, aliados à escassez de mão de obra decorrente da abolição da escravatura fizeram com que Capivari (Silva Jardim) entrasse em colapso no final do século XIX (Abreu, 1994).

A história de desenvolvimento de Silva Jardim está atrelada ao seu bioma, a Mata Atlântica, que foi o atrativo para ocupação e exploração da região desde sua fundação. Ao mesmo tempo em que trazia riqueza ao homem, projetava a esperança da fauna e flora a sua sobrevivência em meio a heterotrofia do crescimento econômico (Abreu, 1994).

A devastação da região pelos períodos da madeira e da agricultura, principalmente nos séculos XVIII e XIX, criou uma paisagem severamente subdividida onde, através dos trabalhos de conscientização e manejo realizados pelas áreas de proteção ambiental juntamente com a parceria dos grandes proprietários, possibilitaram a recuperação local. Nesse cenário, é inegável a importância desses remanescentes e restauração da conectividade entre eles, criando corredores, para assegurar a conservação da biodiversidade dos processos ecológicos na área que é de relevante ocorrência do mico-leão-dourado que, atualmente, é uma espécie bandeira na conservação da Mata Atlântica (Procópio de Oliveira Et al, 2008).

\subsection{1}

\section{Problemas enfrentados gestão municipal integrada para conservação ambiental da Bacia do Rio São João}

A região da Baixada Litorânea localizada no Estado do Rio de Janeiro, vem sofrendo devastação desde sua ocupação, primeiramente pela exploração de madeira e da agricultura, criando assim uma paisagem severamente fragmentada. A Bacia do Rio São João, RJ, recoberta originalmente pela Mata Atlântica, habitat do mico-leão-dourado, é um excelente exemplo da fragmentação da paisagem (Figura 13), onde, através dos trabalhos de conscientização e manejo realizados, possibilitam a recuperação local (Procópio de Oliveira et al, 2008). Nesse cenário, é inegável a importância de uma gestão integradora para a conservação dos fragmentos, indo além dos limites de cada município. 


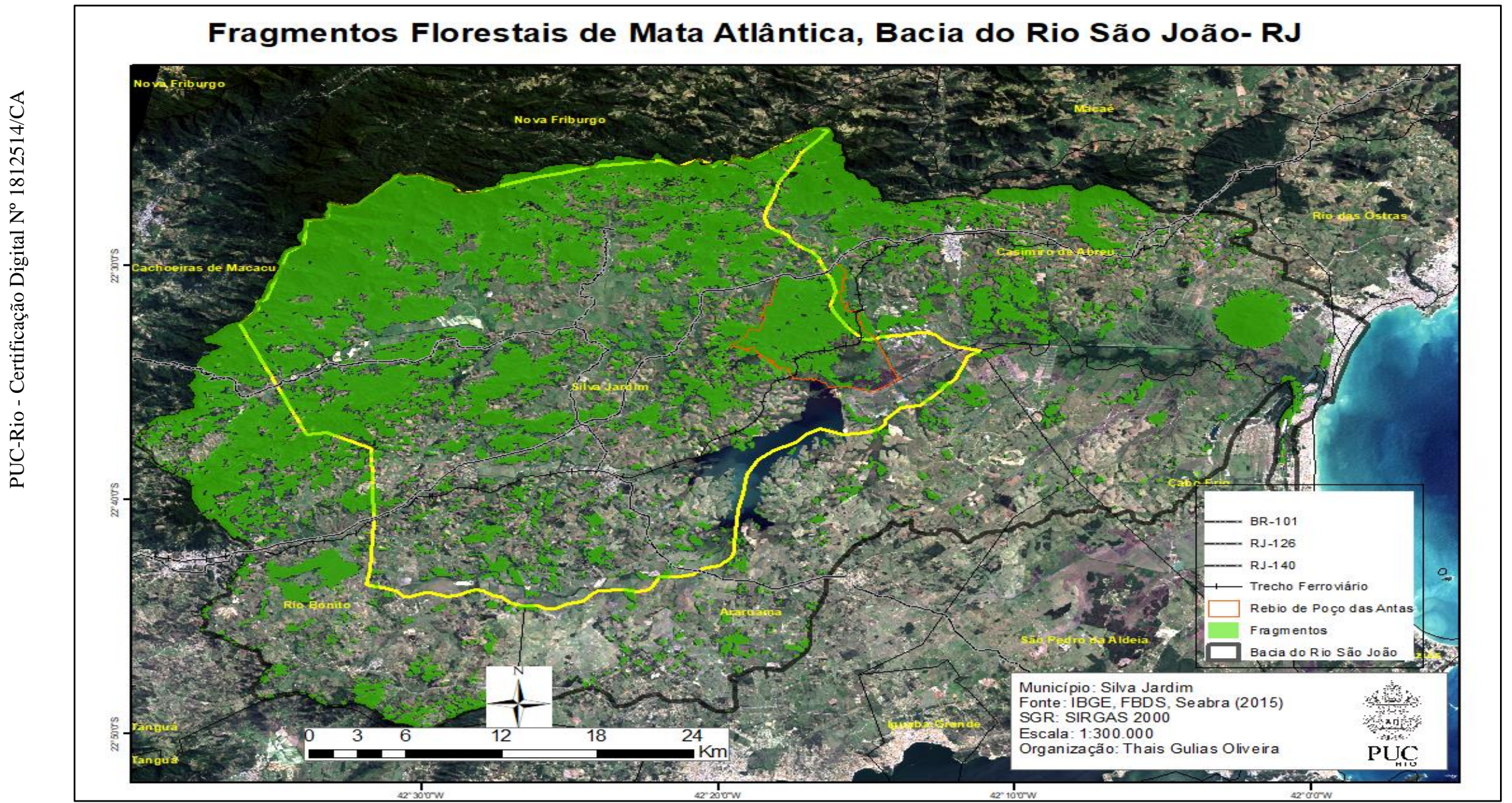

Figura 13. Fragmentos Florestais de Mata Atlântica na Bacia do Rio São João, Silva Jardim- RJ. Fonte: Autora 
A Bacia do Rio São João engloba oito municípios: Araruama, Cabo Frio, Cachoeiro de Macacu, Casimiro de Abreu, Rio Bonito, Rio das Ostras, São Pedro da Aldeia e Silva Jardim (Bidegain, 2005). A conservação dos remanescentes florestais é fundamental para garantir as peculiaridades da paisagem que integra esses municípios. Logo, a remoção de vegetação pode acarretar no desequilíbrio ecológico para muitas espécies e impactar os recursos hídricos (Cunha e Guerra, 2003). Há necessidade de um trabalho intermunicipal para a conservação dos recursos ambientais da área é de grande importância.

Pensando nisso, a abordagem integradora das relações entre natureza e sociedade são fundamentais para a realização de práticas eficientes na gestão ambiental.

Ab'Saber (2003) nos alerta que a alternativa é a conscientização da responsabilidade de todos frente às heranças paisagísticas na busca de um modelo equilibrado, que pretende preservar a natureza na forma de reservas naturais. $\mathrm{O}$ resgate dos valores culturais e técnicos, aliado à busca de novos modos de percepção ambiental adequados a gestão ambiental, são fatores que podem influenciar diretamente na melhoria da qualidade ambiental.

A integração da APA, na Região composta pelos Municípios de Araruama, Cabo Frio, Cachoeiras de Macacu, Casimiro de Abreu, Rio Bonito, Rio das Ostras e Silva Jardim tem consequências para a sua própria gestão e manejo, bem como para a gerenciamento de instituições municipais e para a execução de iniciativas governamentais na área, sendo necessário examinar o caso atual dessas ligação para definir as reais capacidade de cooperação e integração destas com a APA da bacia do Rio São João (ICMBio, 2005 e ICMBio, 2008).

É fundamental salientar que a APA da Bacia do Rio São João já obteve um nível de mérito significativo na região, já realizando um papel importante, com uma competência para contribuir muito mais para um desenvolvimento próprio para a região. Outra relevante medida é a formação de parcerias sociais e a legalização daquelas já existentes com a APA, para apoio às ações de educação ambiental, fiscalização, extensão rural, reforço de pessoal, entre outras (ICMBio, 2008).

A associação com o Consórcio Intermunicipal Lagos São João, que compõe o Conselho Consultivo da APA, é uma das que podem trazer objetivas 
possibilidades de cooperação e integração com a mesma. Da mesma forma, o estabelecimento do Termo de Cooperação Técnica com as municipalidades da Região da APA é de total relevância (Bidegain, 2003 e 2005).

O estímulo de um método de conservação da biodiversidade, como um Sistema de Unidades de Conservação com suas Unidades de Proteção Integral e de Uso Sustentável, vem da adaptação os diversos interesses que existem no ambiente de sua existência (ICMBio, 2008). Além de saber das necessidades dos sujeitos comprometidos, é importante que se consiga integrar a conservação e a recuperação da biodiversidade na produção, gestão e prática das políticas públicas setoriais e locais, que atuam na conservação da Mata Atlântica (Gonçalves, 2002 e Capra, 2003). Pensar que transporte, energia, agricultura, reforma agrária, turismo, indústria, expansão urbana, bem como os programas governamentais podem estabelecer resultados positivos ou negativos sobre o bioma e os espaços protegidos. Para isso é necessário contar com o potencial econômico de cada município para fortalecer a gestão da APA (Figura 14) e assim desenvolver melhores projetos destinados para cada município, mas que no geral fortaleçam todas as partes (Lobo, 2014).

Considerando um meio integrador entre as gestões municipais é preciso pensar a gestão da APA no modelo:

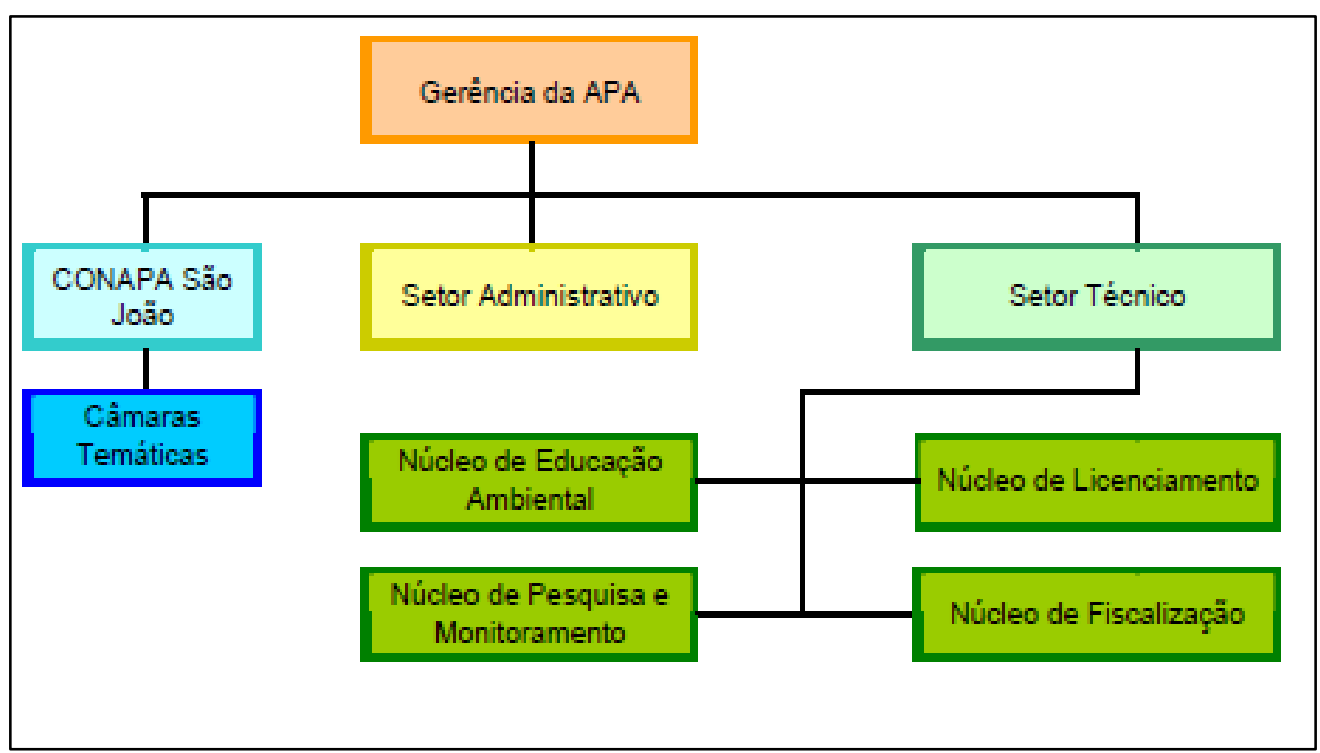

Figura 14 Estruturar a administração da APA conforme o organograma a ser estabelecido no Regime interno intermunicipais.

Fonte: Plano de Manejo, 2008 
Nesse aspecto é preciso que cada prefeitura contribua no que tem de melhor para um avanço na gestão e desenvolvimento capaz de buscar maiores decisões para a conservação, como já mencionado a cima (Lobo, 2014).

De acordo com o IBGE (2012) as seguintes atividades econômicas vêm sendo desenvolvidas com relação às municipalidades inseridas no contexto da APA:

- Araruama - Agronegócios (energia renovável e cana-deaçúcar),agronegócios (fruticultura) e turismo (praias e lagoas);

- Cabo Frio - Agronegócios (energia renovável e cana-deaçúcar),agronegócios (maricultura), confecções (moda praia), turismo (praias) e turismo(náutico);

- Cachoeiras de Macacu - agronegócios (agroindústria artesanal),agronegócios (fruticultura), agronegócios (piscicultura de água doce), bebidas, água mineral e turismo de aventura (ecoturismo);

- Casimiro de Abreu - Turismo (praias);

- Rio Bonito - Cerâmica vermelha;

- Rio das Ostras - Petróleo e gás e turismo (praias);

- Silva Jardim - Cerâmica vermelha, ecoturismo.

Assim a gestão da Bacia do Rio São João vem estabelecendo parcerias pontuais com as prefeituras locais, porém, existe uma grande capacidade para a formação de parcerias que envolvam a compreensão ambiental, a fiscalização e o licenciamento ambiental, sendo este presente tema discutido no âmbito das comissões que busca um melhor planejamento para atingir os objetivos (Bidegain, 2005). Mintzberg, (2004) apud Lobo (2014) nos elucida a importância do planejamento integrado.

No entanto, toda decisão significa comprometimento com a ação e considera o futuro através de uma ação que o tomador de decisão tem razões para tomá-la. Segundo o autor, esta relação decisão versus ação, equivale a um plano. Portanto o planejamento e a decisão estão amarrados, formando a base da ação do administrador. Na definição mais limitada de planejamento enquanto um processo, definia-se que "planejamento é tomada de decisão integrada"

Esses debates vão além dos fatores econômicos, onde é preciso levar em conta a participação social dos múltiplos atores sociais (ONG's, associações de moradores, produtores rurais e pescadores, prefeituras, instituições públicas municipais, estaduais e federais) é importante para realizar um desenvolvimento de gestão mútua da unidade de conservação. Cada sujeito social deve entender como 
a sua organização pode contribuir para desenvolver as iniciativas bem-sucedidas, que na região de dimensão da APA são muitas: REBIO's de Poço das Antas, APA's, várias UC's e RPPN's, Associação Mico-Leão- Dourado, Consórcio Ambiental Lagos São João. Sem falar das iniciativas das prefeituras municipais para revegetação de matas ciliares e mangues, produção de brigadas e fiscais ambientais (ICMBio,2005, 2008, 2011; MMAeICMBio, 2002; IBAMA, 1989). Levando em conta as participações integradas a vivencia local surge a lei:

A Portaria ${ }^{\circ}$ 87, de 7 de dezembro de 2005 criou o Conselho Consultivo da APA da Bacia do Rio São João / Mico-Leão-Dourado, considerando o disposto no $§ 5^{\circ}$ do Art. 15 da Lei 9.985/00, que determina que a APA disporá de um conselho presidido pelo órgão responsável por sua administração e constituído por representantes dos órgãos públicos, de organizações da sociedade civil e da população residente, mostrando que é necessário o cuidado partindo dos que vivenciam a área.

A prova que os debates nas comissões intermunicipais vêm dando resultado

são o conjunto de leis orgânicas aprovadas pelos municípios que visam a proteção da área buscando um bem comum para a conservação. Como exemplo a Seção VIII da Lei Orgânica do município de Silva Jardim, 1990.

Art. $236-(\ldots)$

$\S 1^{\circ}$-- Para assegurar efetivamente esse direito, o Município deverá articular-se com os órgãos estaduais, regionais e federais competentes e ainda, quando for o caso, com outros municípios, objetivando a solução de problemas comuns relativos à proteção ambiental.

(...)

IV -Estimular o reflorestamento ecológico em áreas degradadas, objetivando especialmente a proteção de encostas e de recursos hídricos, a consecução de índices mínimos de cobertura vegetal, o reflorestamento econômico em áreas ecologicamente adequadas, visando suprir a demanda de matéria-prima de origem florestal e a conservação de florestas nativas;

(...)

VI - Proteger as bacias, microbacias e sub bacias hidrográficas, estabelecendo normas de proteção, uso e ocupação das áreas próximas a rios, riachos, canais e córregos;

VII - Proibir à canalização de afluentes de esgotos e a instalação de indústrias químicas, no Município, que comprometam a qualidade da água dos rios, riachos, canais, córregos e da Lagoa de Juturnaíba;

Outras leis em favor da conservação foram aprovadas ao longo dos anos nos municípios pertencentes ao território da Bacia do Rio São João, como apresentados na Tabela 9.

Tabela 7. Leis aprovadas nos municípios que fazem parte da APA do Rio São João visando sua conservação.

\begin{tabular}{ll}
\hline Tipo & Objetivo \\
\hline Lei complementar & Aprova o plano diretor do Município de Rio das Ostras \\
\hline Lei complementar & Aprova o Plano diretor do Município de Cabo Frio \\
\hline
\end{tabular}




\begin{tabular}{ll}
\hline Lei complementar & Aprova o plano diretor do Município Araruama \\
\hline Lei municipal & Aprova o plano diretor do Município Silva Jardim \\
\hline Lei municipal & Aprova o plano diretor do Município Casimiro de Abreu \\
\hline Lei municipal & Aprova o plano diretor do Município Rio Bonito \\
\hline Lei municipal & Aprova o plano diretor do Município Cachoeiras de Macacu \\
\hline Lei orgânica & Institui a Lei Orgânica do Município de Casimiro de Abreu \\
\hline Lei orgânica & Institui a Lei Orgânica do Município Araruama \\
\hline Lei orgânica & Institui a Lei Orgânica do Município Cabo Frio \\
\hline Lei orgânica & Institui a Lei Orgânica do Município Cabo Frio \\
\hline Lei orgânica & Institui a Lei Orgânica do Município Cachoeiras de Macacu \\
\hline Lei orgânica & Institui a Lei Orgânica do Município Rio Bonito \\
\hline Lei orgânica & Institui a Lei Orgânica do Município Silva Jardim \\
\hline Lei orgânica & Institui a Lei Orgânica do Município de Rio das Ostras \\
\hline
\end{tabular}

Fonte: ICMBIO, 2008

Nesse nível é que a Bacia do Rio São João tem seus estímulos mais relevantes sendo postos em forma de leis onde se é possível uma cobrança mais eficaz seja do setor público ou social.

Outros dados que chamam a atenção são os da importância da água demostradas pela SEMADS (2001) no relatório das Bacias Hidrográficas e Rios Fluminenses. Os municípios buscam o desenvolvimento constante da região frente à uma ação de crescimento sem precedentes no estado, afirmando que a distribuição de água e qualidade das águas que atingem a barragem que seguem até sua foz, garante o oficio e sobrevivência dos pescados da bacia hidrográfica, além do bemestar social e biodiversidade dos rios. Mas, chamam a atenção para os problemas e a necessidade de vigilância como cita Oliveira e Mello, 2007.

Associadas a atividade de extração de areia acarretaram e vêm promovendo enormes danos aos ecossistemas. A extração de areia à montante da represa ocorre há muito tempo, concentrando-se atualmente nos leitos dos Rios São João, Pirineus e Bananeiras. Os extratores de areia subiram os rios em busca dos depósitos de areia mais grossa, lavrando em grande parte o leito e as margens dos cursos d'água.

Outros fatores negativos para a conservação local, é a falta de participação de cidades e localidades no interior da APA, levando ao principal fator de enfrentamento, pois da ocupação humana apresentam inúmeras dificuldades decorrentes de suas atividades, como: lixo, esgoto, queimadas, caça, não cumprimento das leis (Silva, 2012 e Cunha e Guerra, 2003).

Estabelecer com que a população residente na região tenha conhecimento da importância de viver em área de uma Unidade de Conservação e da oportunidade de desenvolver programas socioeconomicamente sem afetar a valor ambiental da 
Bacia. Isso deve acontecer por meio da educação dos moradores (Lopes, 2015 e Melo, 2004).

Além disso, há um rico patrimônio histórico e arqueológico, representado por inúmeros sambaquis e casas de engenho na região. Onde é possível entender todo o valor histórico e de ocupação da região que precisa também ser preservado (Seda, 2013).

A proposta da integração regional, que busca uma gestão integrada dos recursos naturais e da promoção do desenvolvimento sustentável, fundamentalmente requer o envolvimento de todos os municípios que se encontram no território da Bacia do Rio São João sem perder as autonomias e particularidades de cada município. Porém que se busque seus pontos principais e mais fortes, principalmente dentro das riquezas econômicas para melhorar a gestão. Não menos importante é preciso estimular as ONGs e projetos sociais, com os quais é necessário manter um diálogo permanente e fluido (Lopes, 2015).

É por isto que a gestão com busca da conservação da Bacia deve contar, como vem fazendo a anos, alianças estratégicas, que ajudam a cumprir os objetivos e metas propostas em projetos de lei. Desta forma, espera-se maior ganho de visibilidade e reconhecimento, destacando mais ainda a importância da Bacia do Rio São João em referência regional e nacional obrigatória para o desenvolvimento e conservação das atividades econômicas regionais, naturais e histórias por meio de cooperação (Gonçalves, 2002).

\section{2}

\section{Espacialização da Lei de Proteção da Vegetação Nativa}

A espacialização da LPVN foi realizada com a definição dos parâmetros de área aplicados a APP e RL, separação dos dados espaciais capazes de identificá-los e escolha das ferramentas no SIG ArcGIS que atendiam o objetivo da espacialização. Esse processo, com detalhes, pode ser observado na metodologia. Porém, os atributos da tabela VI que se encontram tachados/riscados são aqueles que não conseguimos levantar ou especializar por não ter acesso as licenças das propriedades dispersas no município de Silva Jardim.

A espacialização da Lei de Proteção da Vegetação Nativa indicou que 33,2\% da área total do município de Silva Jardim é protegido legalmente. A aplicação da 
lei que mais contribuiu para esse percentual são as APP que protegeriam os recursos hídricos da região, considera

Tabela 8. Total de áreas protegido pela LPVN

\begin{tabular}{llllll}
\hline $\begin{array}{l}\text { LPVN de } \\
\text { proteção } \\
\text { hídricos }\end{array}$ & $\begin{array}{l}\text { LPVN de } \\
\text { proteção de } \\
\text { Reserva } \\
\text { Legal }\end{array}$ & $\begin{array}{l}\text { LPVN de } \\
\text { proteção de } \\
\text { Relevo }\end{array}$ & Total & $\begin{array}{l}\text { Área total } \\
\text { de Silva } \\
\text { Jardim }\end{array}$ & $\begin{array}{l}\text { Porcentagem } \\
\text { total de área } \\
\text { protegida }\end{array}$ \\
\hline $17286 \mathrm{ha}$ & $13103 \mathrm{ha}$ & $834 \mathrm{ha}$ & $31223 \mathrm{ha}$ & $93843 \mathrm{ha}$ & $33,2 \%$ \\
\hline
\end{tabular}

Fonte: Autora

É possível observar que a área referente a proteção do relevo é bem pequena em relação às demais. Outro dado que chama atenção é a área de proteção referente a Reserva Legal, visto que esse é um dado declarado pelo proprietário rural ao cadastrar seu imóvel no Cadastro Ambiental Rural (CAR). Como o sistema do CAR ainda é recente, não está claro se existem restrições de quantidade de móveis cadastrados e confiabilidade de informações, portanto, podem não representar a realidade em sua totalidade (Issi et al. 2018).

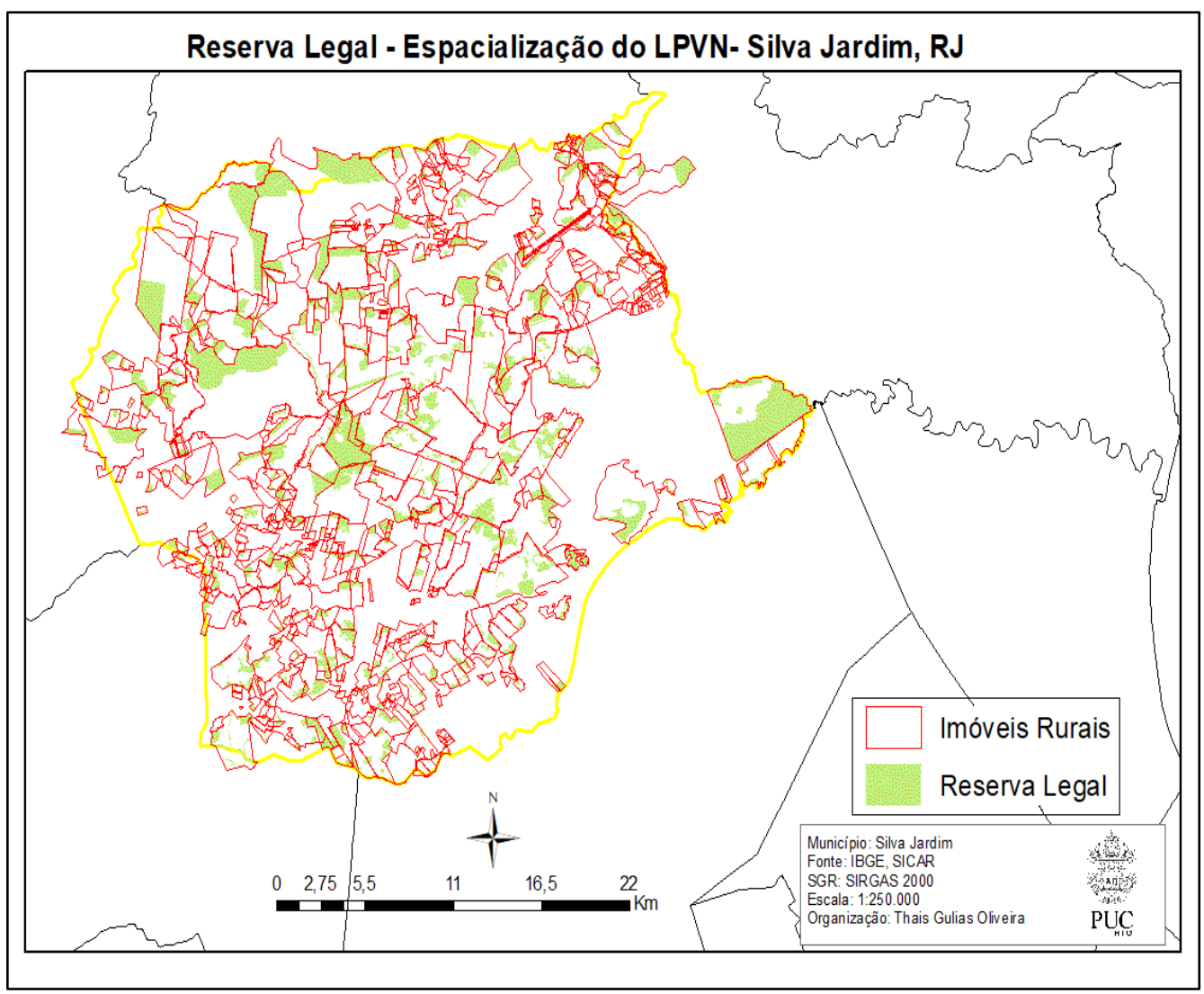

Figura 15. Espacialização das Reservas Legais em Silva Jardim, RJ.

Fonte: Autora 
Alguns parâmetros estabelecidos para proteção de APP, não foram possíveis especializar, como os reservatórios de água artificial, para isso era necessário o acesso as licenças das propriedades presentes no município de Silva Jardim, dados que o CAR não disponibiliza a uso público.

Nas figuras abaixo temos a espacialização das áreas de APP's e podemos observar que em grande maioria dessas se encontram dentro de propriedades rurais, como o exemplo de uma propriedade ao sul do municio de Silva Jardim (Figura 16).

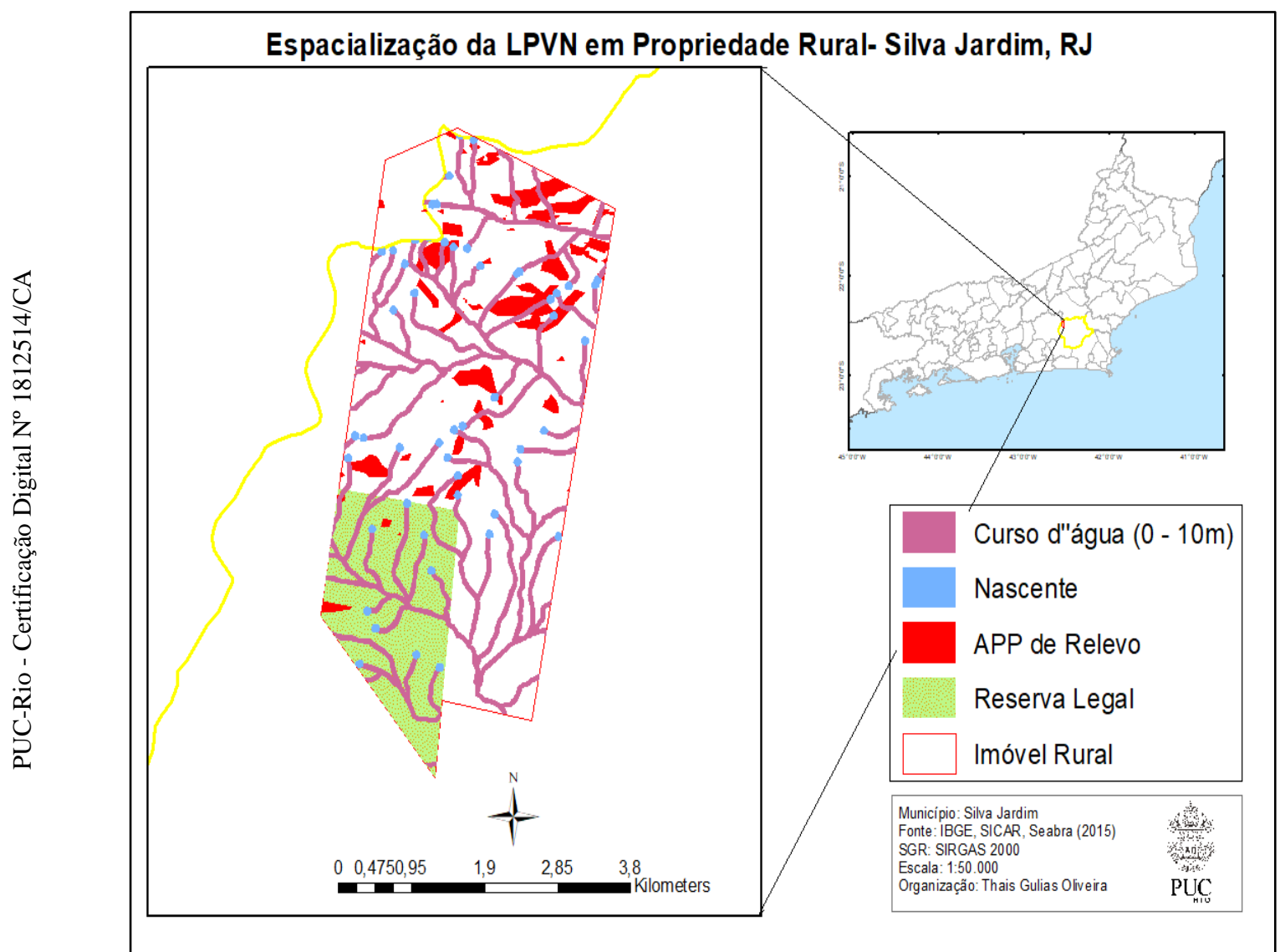

Figura 16. Espacialização das leis da LPVN em uma propriedade rural.

Fonte: Autora

É comumente encontrado dentro de propriedades rurais as áreas de encostas acentuadas, os cursos d'água protegidos por suas matas ciliares, os rios e reservatórios, áreas de nascente. Através dessas áreas é possível indicar vários elementos para benefício ambiental decorrente de sua conservação. Um exemplo disso é a degradação das matas ciliares em cursos d'água e das áreas de nascentes, 
a falta de conscientização da conservação dessas reflete na escassez de água para o abastecimento urbano.

As maiores área protegidas pela lei dentro do município de Silva Jardim está ligada aos fatores hídricos (17286 ha), principalmente os cursos d'água até 10 metros (Figura 17.)

$\mathrm{Na}$ figura da próxima página conseguimos ver com detalhes todos os cursos d'água mapeados, em roxo são os cursos d'água de até 10 metros, como relatado anteriormente e visivelmente sua maioria no recorte espacial escolhido da pesquisa. 


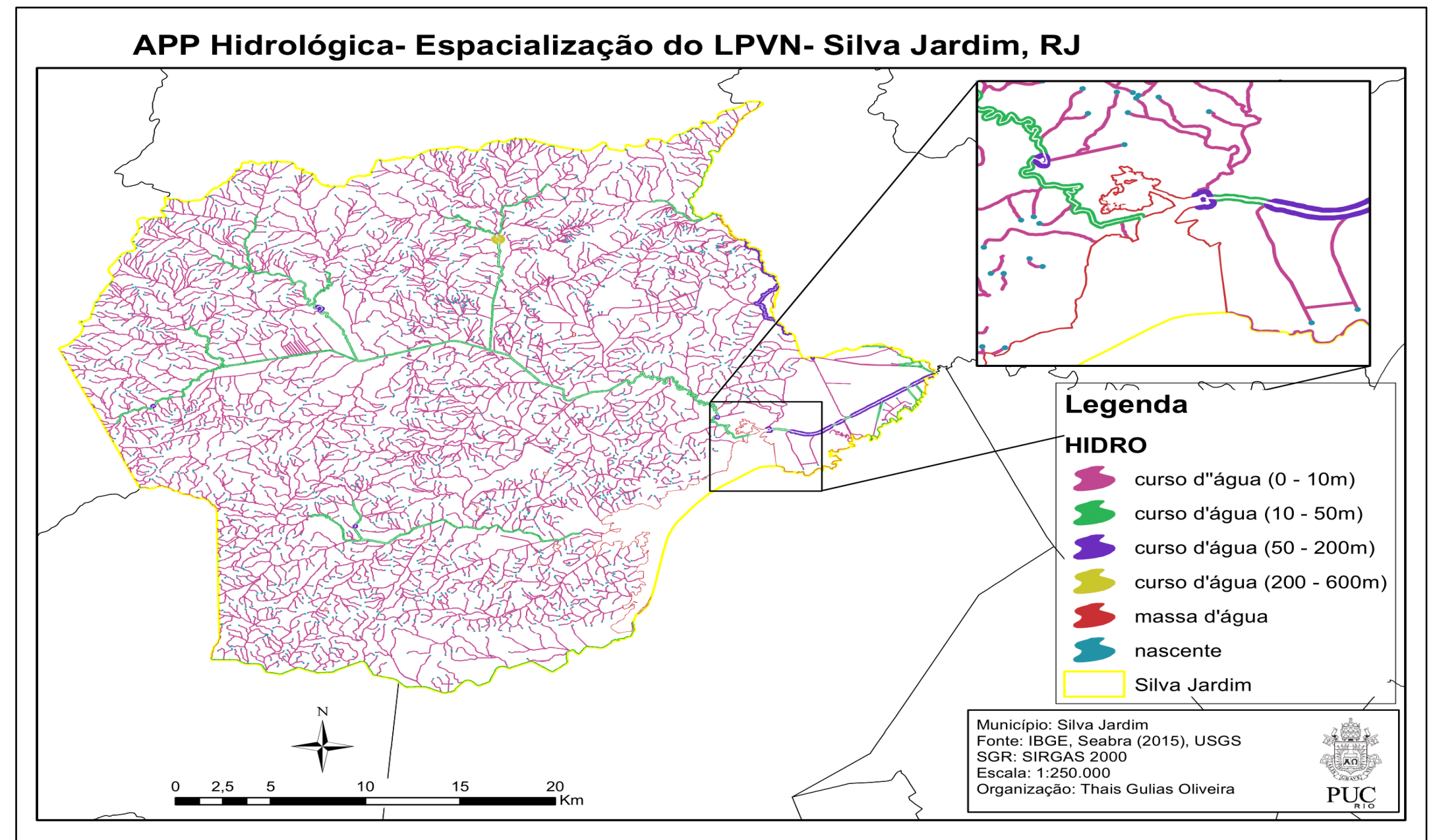

Figura 17. Espacialização das APP's de Hidrologia no município de Silva Jardim, RJ.

Fonte: Autora 
Foram identificadas poucas áreas de relevo acentuado (834 ha). Elas se encontram mais ao sul do município, próximo a Serra de Macaé de Cima e a divisa com Nova Friburgo (Seabra, 2015).

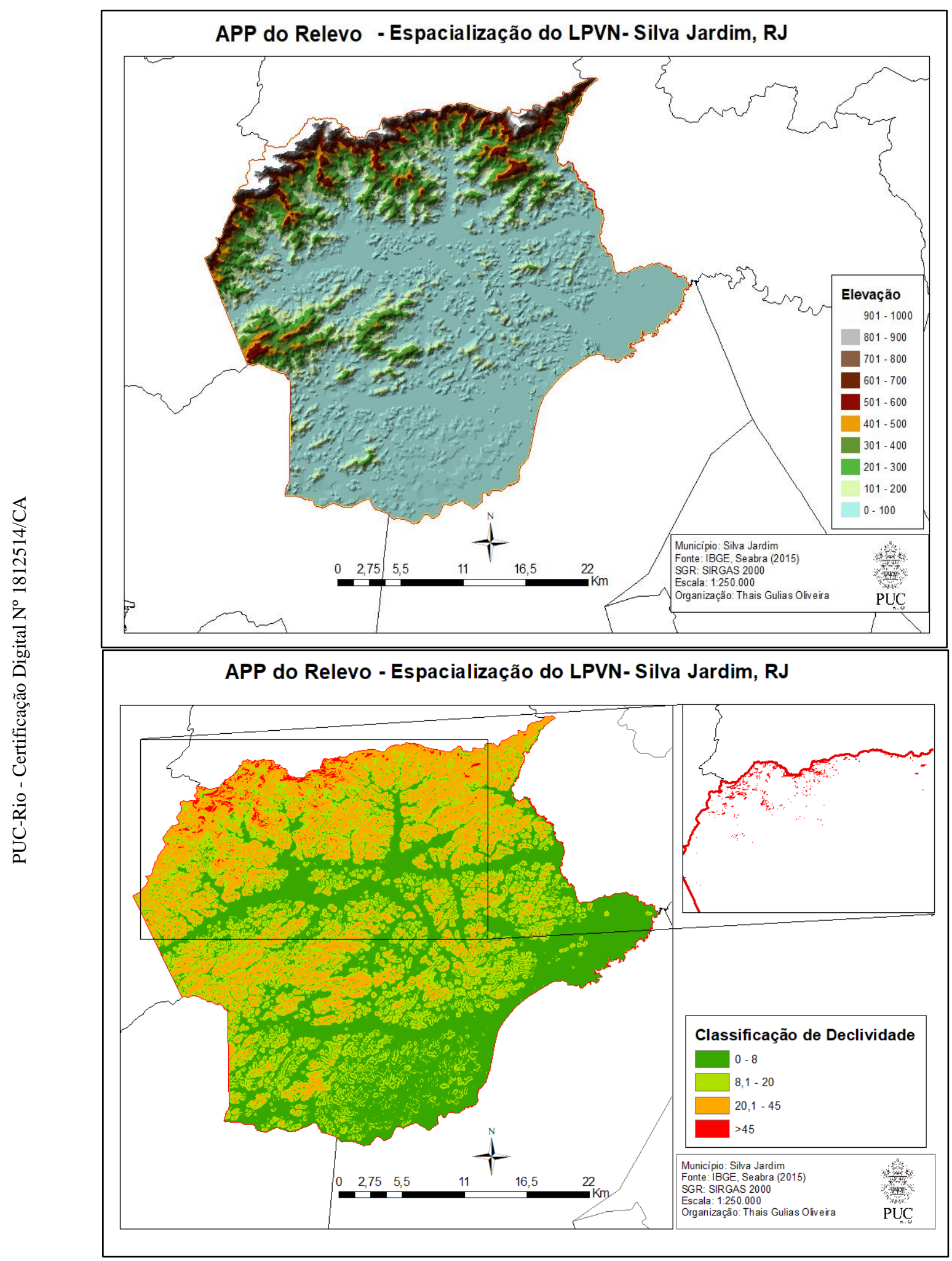

Figura 18. Espacialização as APP's de Relevo no município de Silva Jardim, RJ.

Fonte: Autora 


\section{3}

\section{Métricas de paisagem}

A aplicação dos cálculos de métricas de paisagem gerados pelo V-Late nas classes de 1 a 5 , segmentadas por tamanho crescente, deram origem a tabela abaixo. Nela é possível analisar os índices de área, densidade e tamanho, borda, forma, proximidade e área core.

Tabela 9. Métricas por Classe de fragmento.

\begin{tabular}{|c|c|c|c|c|c|c|c|}
\hline \multicolumn{2}{|c|}{ Índices } & & \multicolumn{5}{|c|}{ Classes dos fragmentos por hectares } \\
\hline Grupo & Métricas & $\begin{array}{l}\text { Sigl } \\
\mathrm{a}\end{array}$ & $\begin{array}{l}1(0-1 \\
\text { ha) }\end{array}$ & $\begin{array}{l}2 \text { ( } 1-10 \\
\text { ha) }\end{array}$ & $\begin{array}{l}3(10-50 \\
\text { ha) }\end{array}$ & $\begin{array}{l}4(50- \\
100 \text { ha) }\end{array}$ & $\begin{array}{l}5(100- \\
500 \text { ha) }\end{array}$ \\
\hline \multirow[t]{2}{*}{ Área } & $\begin{array}{l}\text { Área da } \\
\text { Classe }\end{array}$ & $\mathrm{CA}$ & $\begin{array}{c}3063760 \\
, 59\end{array}$ & $\begin{array}{c}15408038 \\
, 34\end{array}$ & $\begin{array}{c}25404669 \\
, 28\end{array}$ & $\begin{array}{c}16235605 \\
, 05\end{array}$ & $\begin{array}{c}346358214 \\
, 37\end{array}$ \\
\hline & $\begin{array}{l}\text { Porcentag } \\
\text { em da } \\
\text { paisagem }\end{array}$ & PP & 0,33 & 1,64 & 2,71 & 1,73 & 36,91 \\
\hline \multirow[t]{3}{*}{$\begin{array}{c}\text { Densidad } \\
\text { e e } \\
\text { Tamanho }\end{array}$} & $\begin{array}{c}\text { Número } \\
\text { de } \\
\text { mancha }\end{array}$ & NP & 724 & 511 & 116 & 26 & 25 \\
\hline & $\begin{array}{l}\text { Tamanho } \\
\text { médio da } \\
\text { mancha }\end{array}$ & $\begin{array}{l}\text { MP } \\
\text { S }\end{array}$ & 4231,71 & 30152,72 & $\begin{array}{c}219005,7 \\
7\end{array}$ & $\begin{array}{c}624446,3 \\
5\end{array}$ & $\begin{array}{c}13854328 \\
57\end{array}$ \\
\hline & $\begin{array}{l}\text { Desvio } \\
\text { padrão do } \\
\text { tamanho } \\
\text { da } \\
\text { mancha }\end{array}$ & $\begin{array}{l}\text { PSS } \\
\text { D }\end{array}$ & 2594,93 & 20215,22 & $\begin{array}{c}113897,5 \\
8\end{array}$ & $\begin{array}{c}106709,4 \\
9\end{array}$ & $\begin{array}{c}41122754 \\
97\end{array}$ \\
\hline \multirow[t]{2}{*}{ Borda } & $\begin{array}{c}\text { Total de } \\
\text { bordas }\end{array}$ & TE & $\begin{array}{c}240709 \\
55\end{array}$ & $\begin{array}{c}526212,9 \\
8 \\
\end{array}$ & $\begin{array}{c}402556,8 \\
6 \\
\end{array}$ & $\begin{array}{c}204120,2 \\
2 \\
\end{array}$ & $\begin{array}{c}2072161,0 \\
7 \\
\end{array}$ \\
\hline & $\begin{array}{c}\text { Densidad } \\
\text { e de } \\
\text { bordas }\end{array}$ & ED & 785,67 & 341,52 & 158,46 & 125,72 & 59,83 \\
\hline Forma & $\begin{array}{l}\text { Índice de } \\
\text { forma } \\
\text { médio }\end{array}$ & MSI & 1,721 & 1,732 & 2,125 & 2,793 & 5,528 \\
\hline $\begin{array}{l}\text { Proximid } \\
\quad \text { ade }\end{array}$ & $\begin{array}{l}\text { Distância } \\
\text { média do } \\
\text { vizinho } \\
\text { mais } \\
\text { próximo }\end{array}$ & $\begin{array}{l}\mathrm{MN} \\
\mathrm{N}\end{array}$ & 6,23 & 30,80 & 294,57 & 18,64 & 89162,80 \\
\hline $\begin{array}{l}\text { Área } \\
\text { Core }\end{array}$ & $\begin{array}{l}\text { Área } \\
\text { Núcleo } \\
\text { Total da } \\
\text { Classe }\end{array}$ & $\begin{array}{l}\mathrm{TC} \\
\mathrm{A}\end{array}$ & 0 & 51000,81 & $\begin{array}{c}3176583 \\
53\end{array}$ & $\begin{array}{c}3610131, \\
03\end{array}$ & $\begin{array}{c}200631049 \\
, 17\end{array}$ \\
\hline
\end{tabular}




\subsection{1}

\section{Segmentação da Paisagem por tamanho dos Fragmentos}

Como descrito anteriormente foi realizado a classificação dos fragmentos em categorias de tamanho sendo:

Tabela 10. Segmentação da Paisagem por classe de tamanho.

\begin{tabular}{ccc}
\hline Classe & Hectares & Classe de tamanho \\
\hline $\mathbf{1}$ & $\geq 0$ até 1 ha & Muito Pequenos \\
\hline $\mathbf{2}$ & $>1$ até 10 ha & Pequenos \\
\hline $\mathbf{3}$ & $>10$ até 50 ha & Médios \\
\hline $\mathbf{4}$ & $>50$ até 100 ha & Grandes \\
\hline $\mathbf{5}$ & $>100$ até $\geq 500$ ha & Muito Grandes \\
\hline
\end{tabular}

Fonte: Adaptação de Abdalla, 2015.

Tendo o total de 1402 fragmento mapeados pelo Fundação Brasileira para o Desenvolvimento Sustentável em 2013. A Classe 1, possui 724 fragmentos, considerados muito pequenos. A Classe2, possui 511 fragmentos. A Classe 3, possui 116 fragmentos. A Classe 4, 26 fragmentos. A Classe 5, 25 fragmentos.

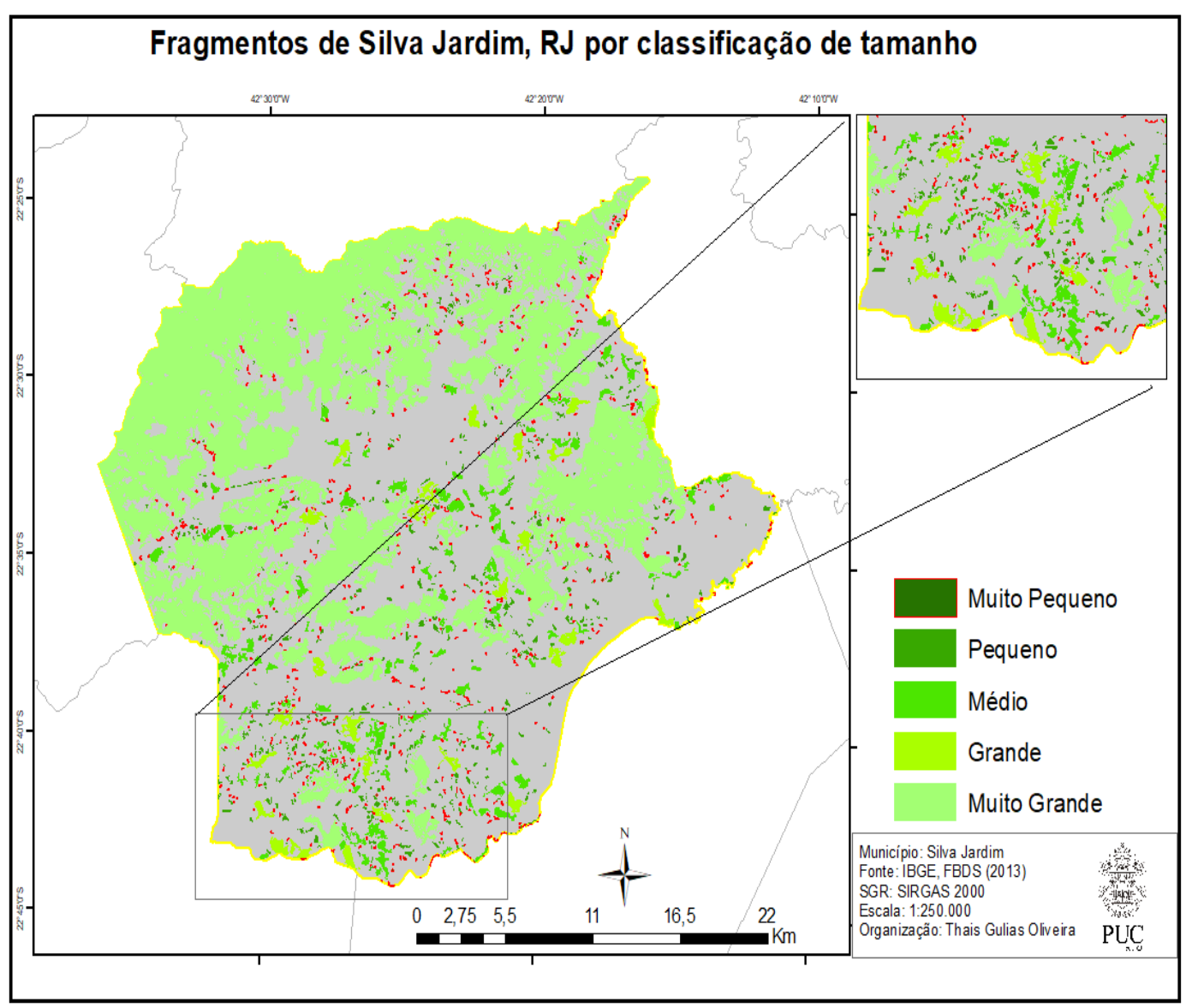

Figura 19. Espacialização dos fragmentos por tamanho em Silva Jardim, RJ.

Fonte:Autora 
Observando a relação entre o valor total das áreas dos fragmentos pelo número de fragmentos dentro de cada classe é possível observar que a Classe 1 possui um número expressivo de fragmentos, porém a soma total deles é pequena. Já a Classe 5 possui o menor número de fragmentos, mas mostra a somar total da área física com maior percentual em relação ao município de Silva Jardim, RJ.

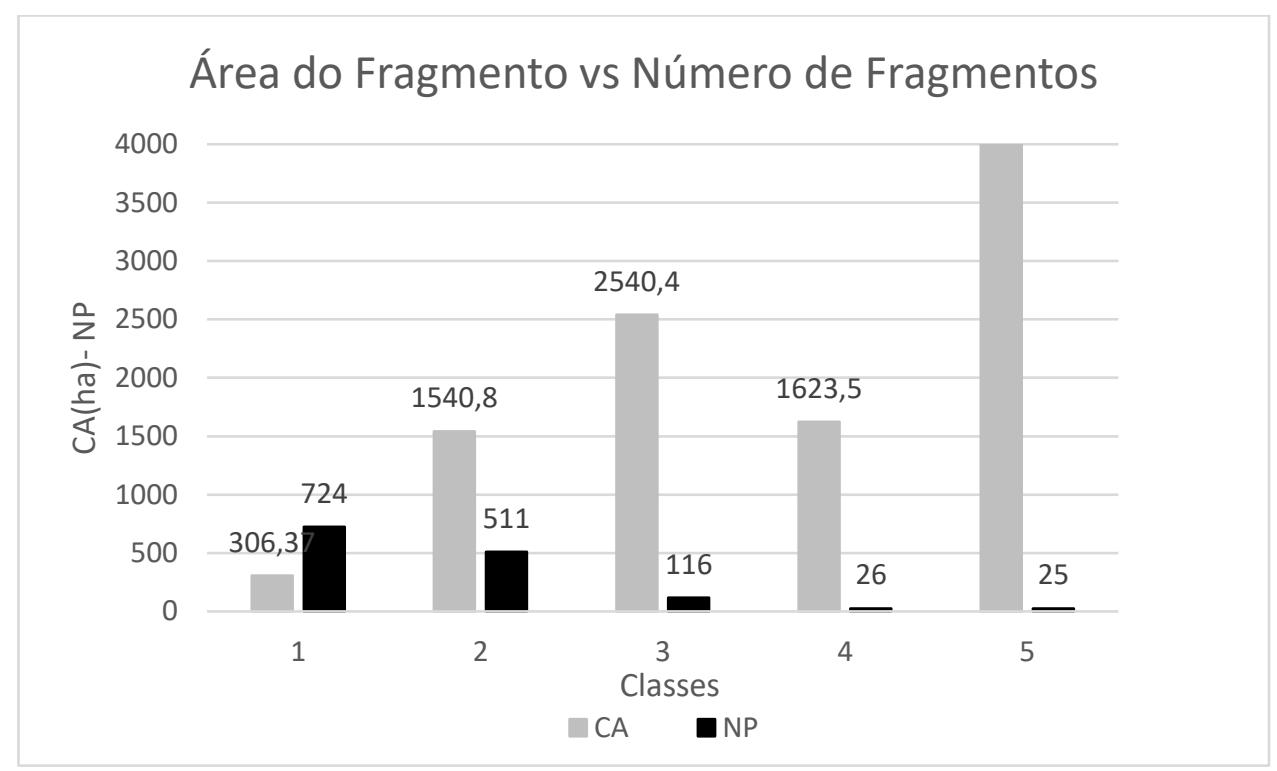

Figura 20. Gráfico de Área do Fragmento vs Número de Fragmentos.

Fonte: Autora

\subsection{2 \\ Métricas de Área, densidade e tamanho}

O Gráfico apresenta a quantidade total da soma das áreas de cada classe de fragmentos florestais, sendo que a maior área total é ocupada pela soma dos fragmentos da classe 5 com fragmentos de 101 ha à 21027,5 ha. A soma das áreas totais das classes 2, 4 e 3, de forma crescente, são bem próximas, com um intervalo de 1 mil hectares. A menor soma é da classe 1, que são os muito pequenos, com fragmentos que vão de 0,076 ha a 0,993 ha. Ranta (1998) aponta que quanto menor o fragmento, menor sua riqueza de espécies e densidade de espécies, isso se reflete de forma negativa na fauna e flora local. 


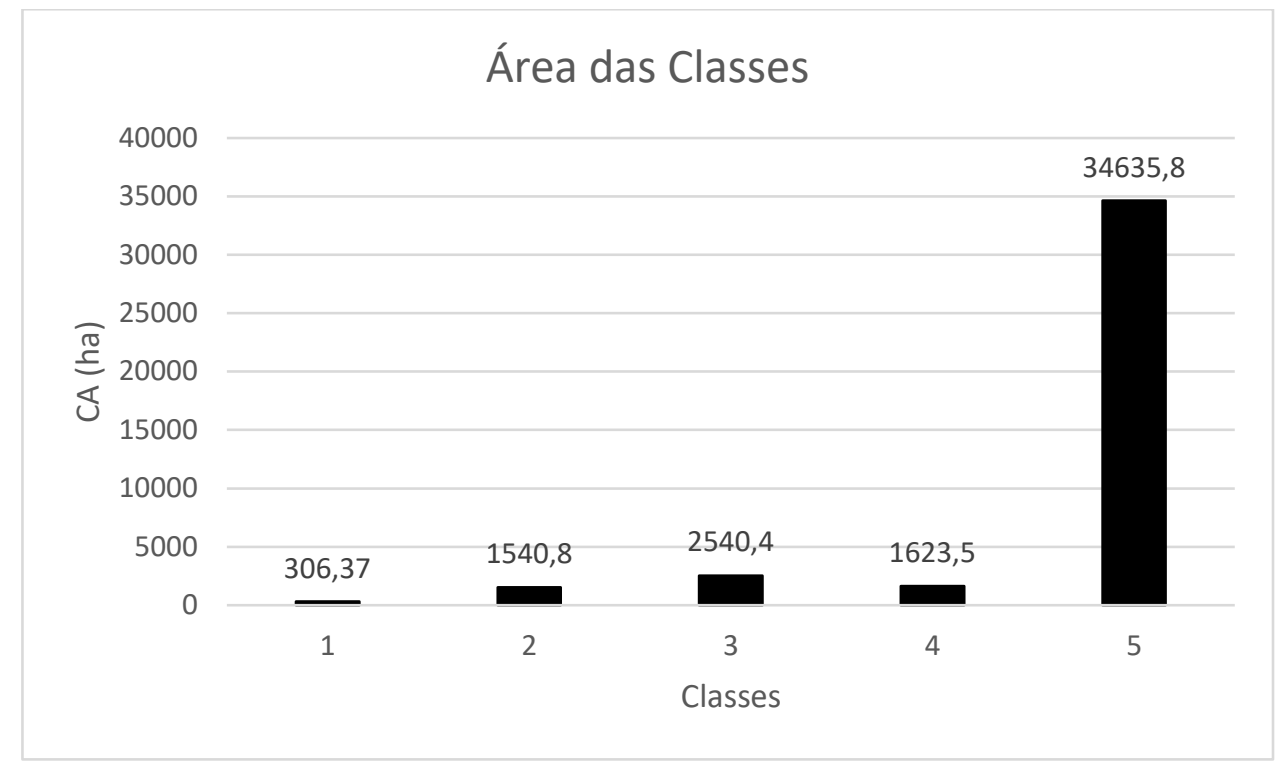

Figura 21. Gráfico da Área das Classes.

Fonte: Autora

O gráfico de número de fragmentos é muito expressivo quando comparado ao de área como vimos no item acima. Observando o gráfico sozinho, a classe 1 e 2 são as que tem o maior número de fragmentos sendo 1235 que vale a $88 \%$ da soma total das classes que é 1402 fragmentos. A classe 4 e 5, com 26 e 25 fragmentos respectivamente, são 3,7\% quando comparamos com o total de fragmentos.

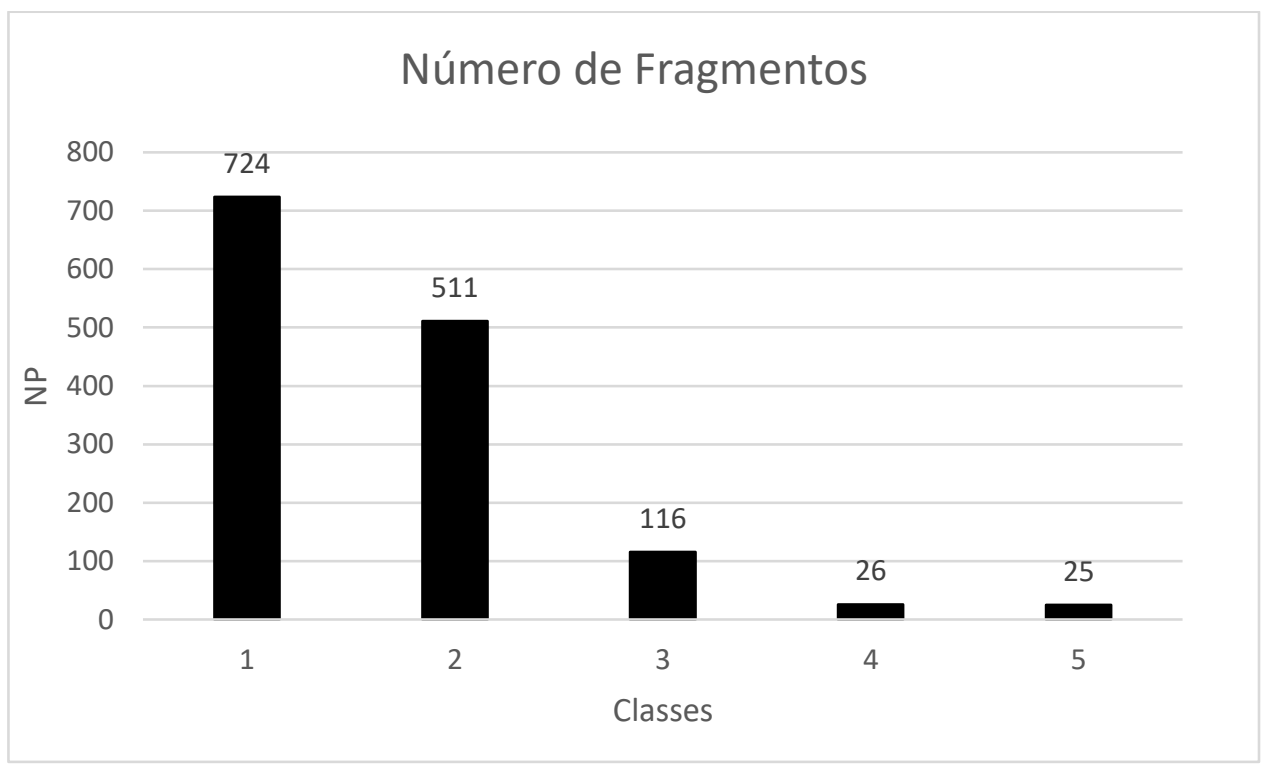

Figura 22. Gráfico de Número de Fragmentos.

Fonte: Autora

Quando comparamos a porcentagem das classes dentro da paisagem em relação a área total de Silva Jardim vemos um gráfico oposto ao de número de 
fragmentos. A Classe 1 apresenta $0,33 \%$ do total da paisagem por seus fragmentos serem muito pequenos e Classe 5 corresponde a $36,91 \%$ da paisagem, pois a soma de suas áreas é a maior dentre as demais. Já a classe 3 apresenta um percentual maior que a classe 2 e 4, devido a soma da área total de seus fragmentos serem maior que suas classes vizinhas.

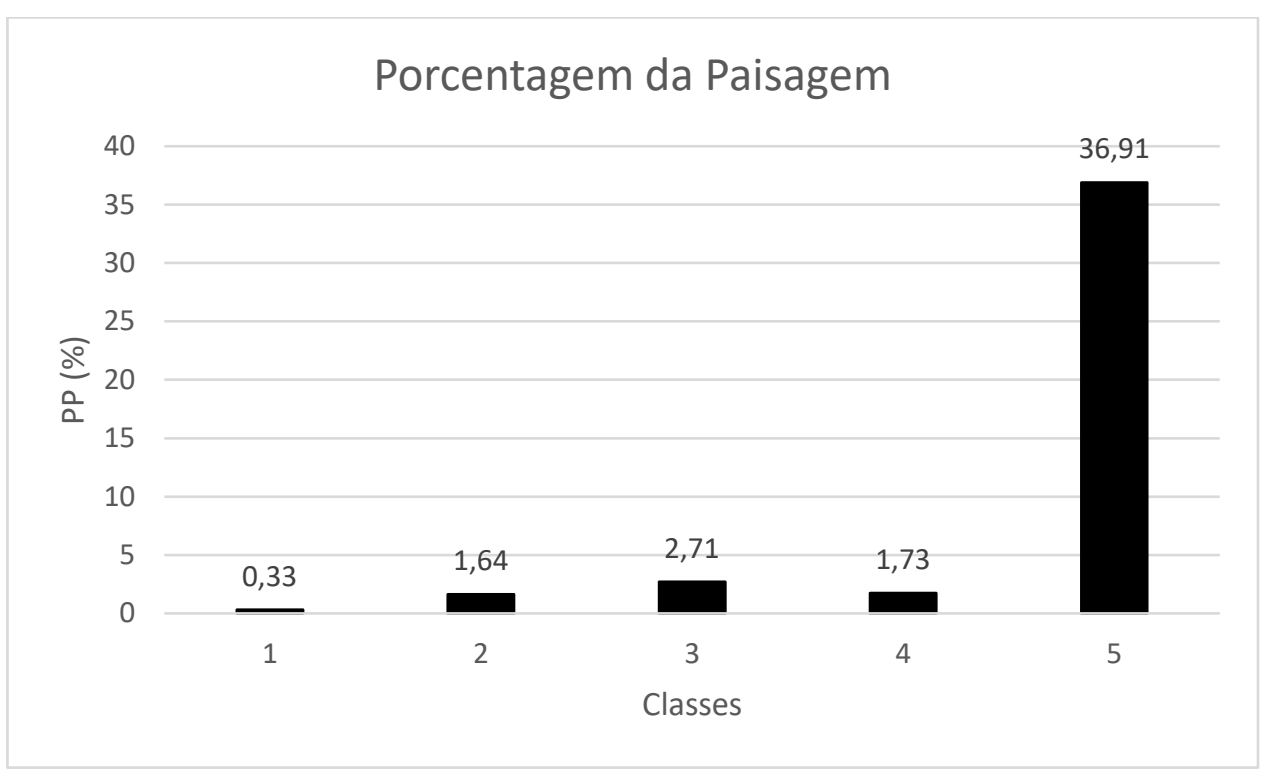

Figura 23. Gráfico de Porcentagem da Paisagem.

Fonte: Autora

Abaixo temos o gráfico de Número de fragmentos vs. Tamanho médio do fragmento, que segundo McGarigal e Marks (1994) quando o número de manchas (NP) for maior e houver a diminuição do tamanho médio da mancha (MPS) expressado em cada classe, teremos como resultado: fragmentos com áreas menores e maior fragmentação. Já quando ocorrer a diminuição do número de fragmentos e o aumento do tamanho médio apresentam manchas com áreas maiores e menor fragmentação. A análise de McGarigal (1994) se reflete no gráfico claramente nas classes 1,2 e 5 . 


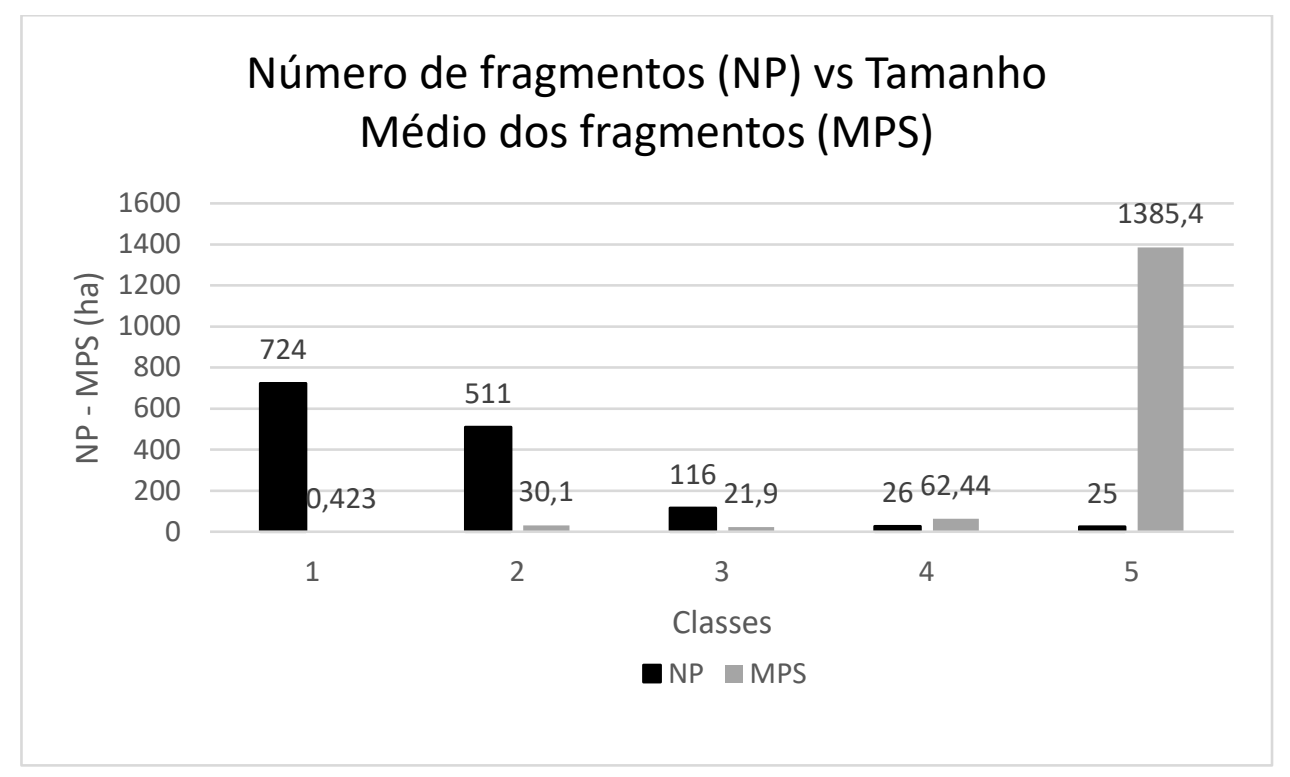

Figura 24. Gráfico Número de Fragmentos vs Tamanho Médio dos fragmentos.

Fonte: Autora

Quando aplicado o desvio padrão sobre o tamanho médio dos fragmentos por classes temos as classes de 1 a 4 indicando padrões médios menores ou bem próximo que seu tamanho médio, isso indica uma baixa diferenciação entre os fragmentos, isso ocorre principalmente ao quantitativo elevado de fragmentos com áreas pequenas. Também se observar uma amplitude na classe 5 o que indica um desvio padrão bem elevado, mostrando que há fragmentos com tamanho acima da mediana estabelecida pela classe.

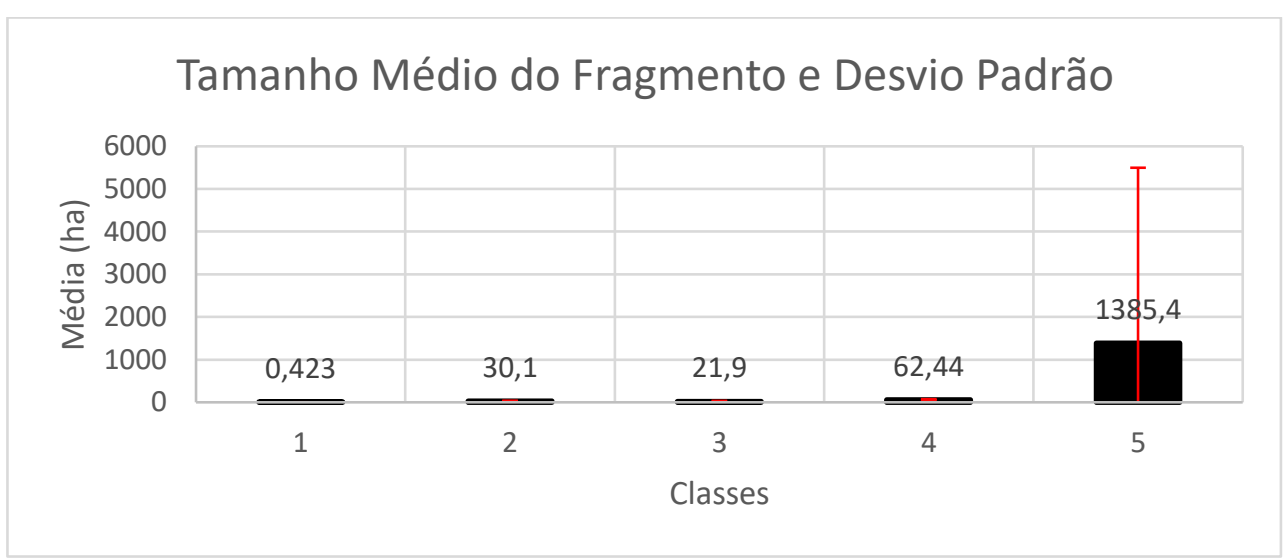

Figura 25. Gráfico de Tamanho Médio do Fragmento e Desvio Padrão.

Fonte: Autora 
5.3 .3

Índices de Borda

O índice de borda total aponta um predomínio da paisagem pela classe 5, isso ocorre por ser a classe com maior soma total de áreas entre os fragmentos. A classe 2 se salienta nessa análise ao realizarmos a soma de suas bordas.

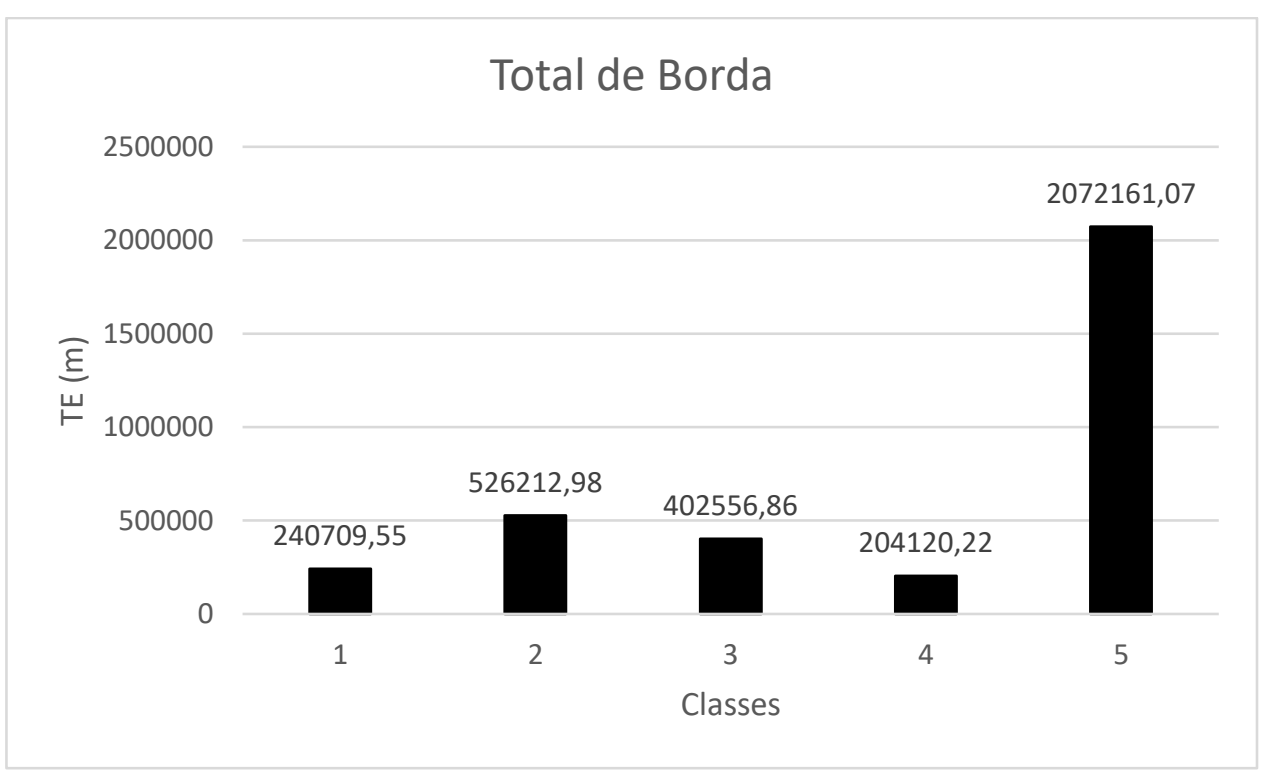

Figura 26. Gráfico de Total de Borda.

Fonte: Autora

No exame do gráfico de densidade borda é observado a classe 1 expondo o maior efeito de densidade de bordas, isso ocorre por ser a classe expressa dos pequenos fragmentos. A densidade de borda é contrariamente proporcional a sua área total de fragmentos. Quando se é analisado o efeito de borda de fragmentos, a classe 5 é a mais apta a conservação visto que é menor o efeito de borda em fragmentos de grande extensão (Ribeiro, 2008).

De acordo com Ribeiro (2008) o efeito de borda em fragmentos com áreas menores é mais intenso, principalmente na transição desses para a paisagem vizinha. Isso se reflete nas alterações abióticas e tais mudanças têm a ver com variações no microclima, aumento de temperatura e déficit hídrico, o que leva a extinção de espécies e invasão de espécies exóticas. 


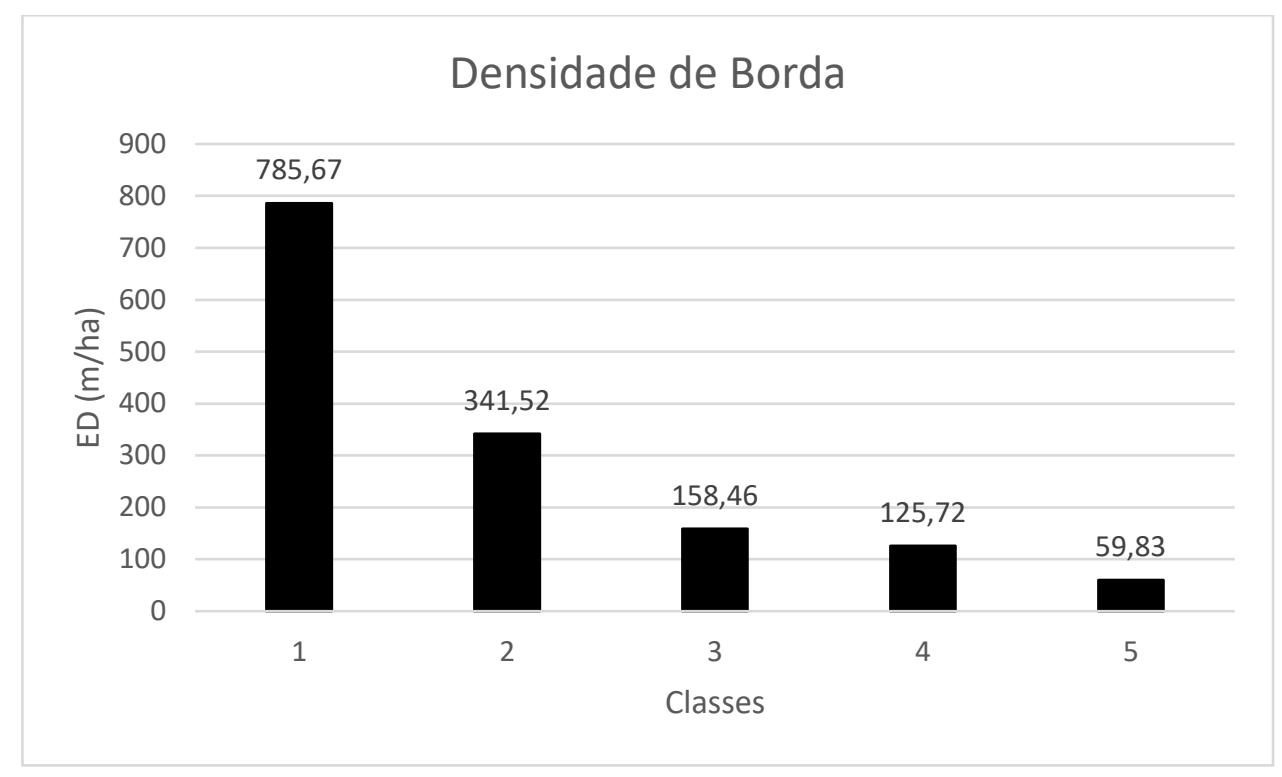

Figura 27. Gráfico de Densidade de Borda.

Fonte: Autora

\section{3 .4}

\section{Índice de Forma}

O índice de forma médio segundo McGarigal e Marks (1994) e Lang (2003) devem se aproximar de 1, onde tem a forma mais simples e circulares. Sendo, superiores a 2 o fragmento apresenta uma forma muito irregular, ou como eles designam de complexa, pois o torna vulnerável aos efeitos de borda.

As classes 1 e 2, apresentam proximidade ao índice ideal que é 1, porém com tendência a se tornarem irregulares por serem um pouco menos que 2 , isso ocorre por esses fragmentos serem pequenos e mais sucessíveis a ação antrópica devido sua distribuição espacial. A classe 5 com 5,528 de índice nos mostra uma composição completamente irregular e ao se atentar a imagem constatamos suas bordas bem flexuosas, porém devido a apresentar grande tamanho o efeito de borda é ignorado, porque esse fator permite que a biodiversidade interna do fragmento seja protegida (Ranta, 1998). 


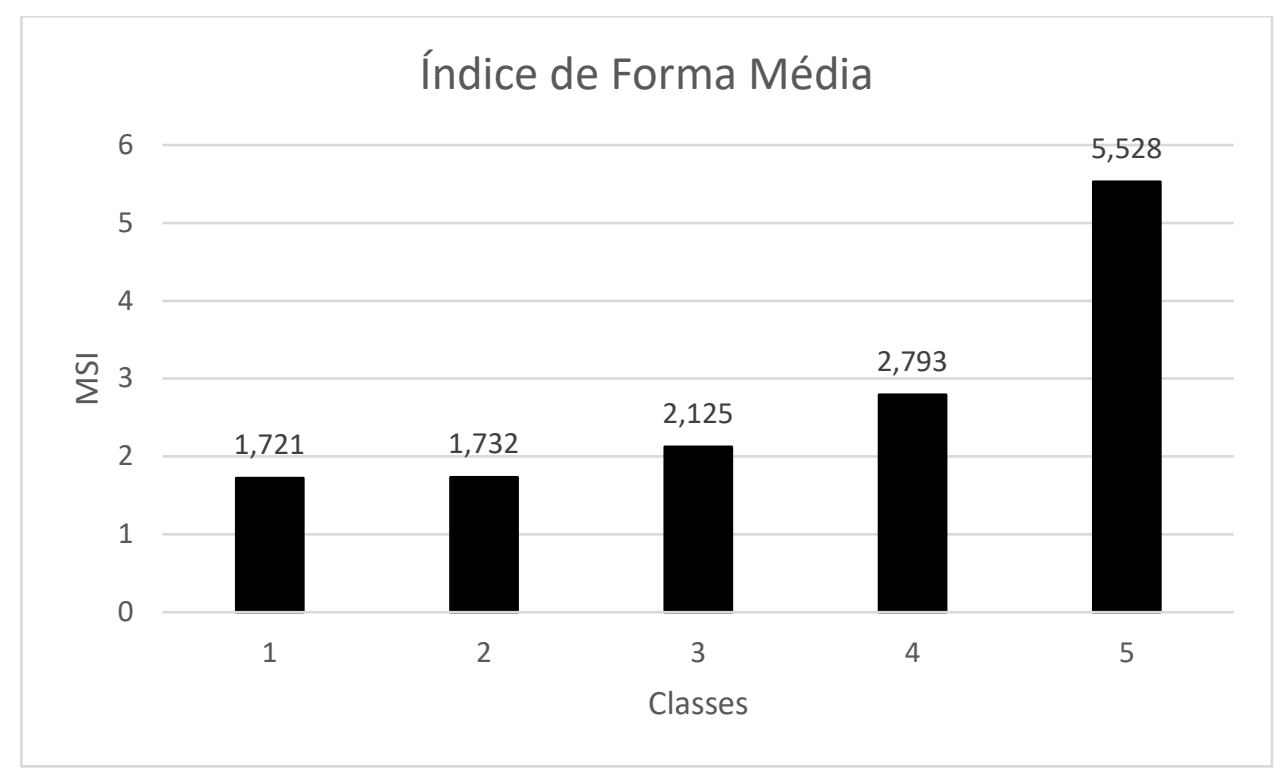

Figura 28. Gráfico de Índice de Forma Média.

Fonte: Autora

\section{3 .5}

\section{Índice de proximidade}

Seguindo o manual de análise de Lang (2003), onde, os valores são iguais a zero quando não se tem manchas do mesmo tipo perto, e, na medida em que aumentam as manchas, os valores e a proximidade entre os fragmentos da mesma classe se tornam maiores. Ao analisar o gráfico o MNN que indica a distância média do vizinho mais próximo sendo a soma de todas as distancias entre cada fragmento e o vizinho mais próximo da mesma classe dividido pelo número de fragmentos por classe (McGarigal e Marks, 1994). Então, é possível observar que a Classe 5 apresenta um alto grau de proximidade, ou seja, mostrando estar mais bem conservadas que as demais classes. A classe 1 indica os menores resultados de MNN e como indica MacArthur e Wilson (1967): quanto maior a distância, pior o efeito de conservação do fragmento. 


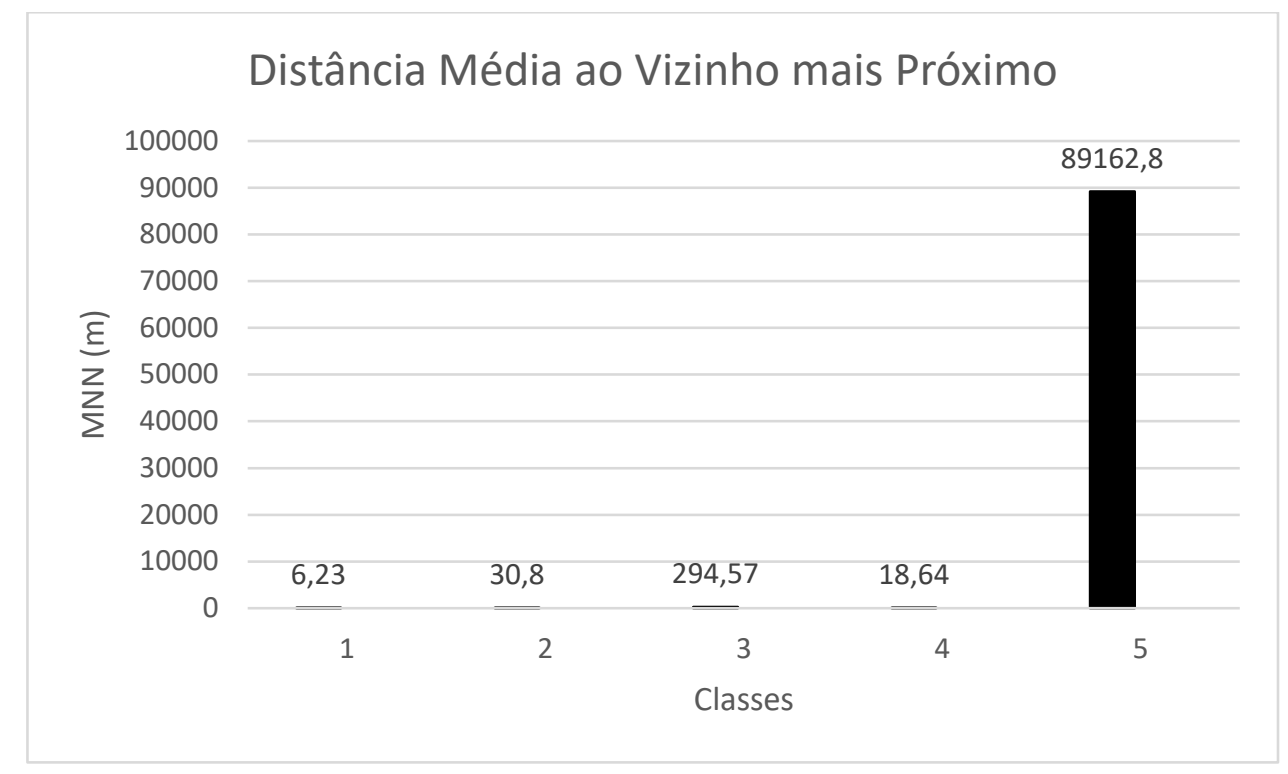

Figura 29. Gráfico de Distância Média ao Vizinho mais próximo.

Fonte: Autora

\section{3 .6} Índice de Área Núcleo

A área central foi estipulada em 100 metros que é o deslocamento mínimo de um mamífero de pequeno porte saudável por dia (Crouzeilles, 2010). Com a escala estipulada os pequenos fragmentos se anulam. Pois quando menor o fragmento mais próximo a distância do centro da borda, elevando o efeito de borda. Já os resultados das métricas de área central apontam para o fato de que, quanto maior o tamanho do fragmento maior será sua área central total (TCA), observamos isso na classe 5 e menor será o percentual de sua área afetado pelo efeito de borda como vimos no índice de borda (Lang, 2003 e McGarigal e Marks, 1994). 


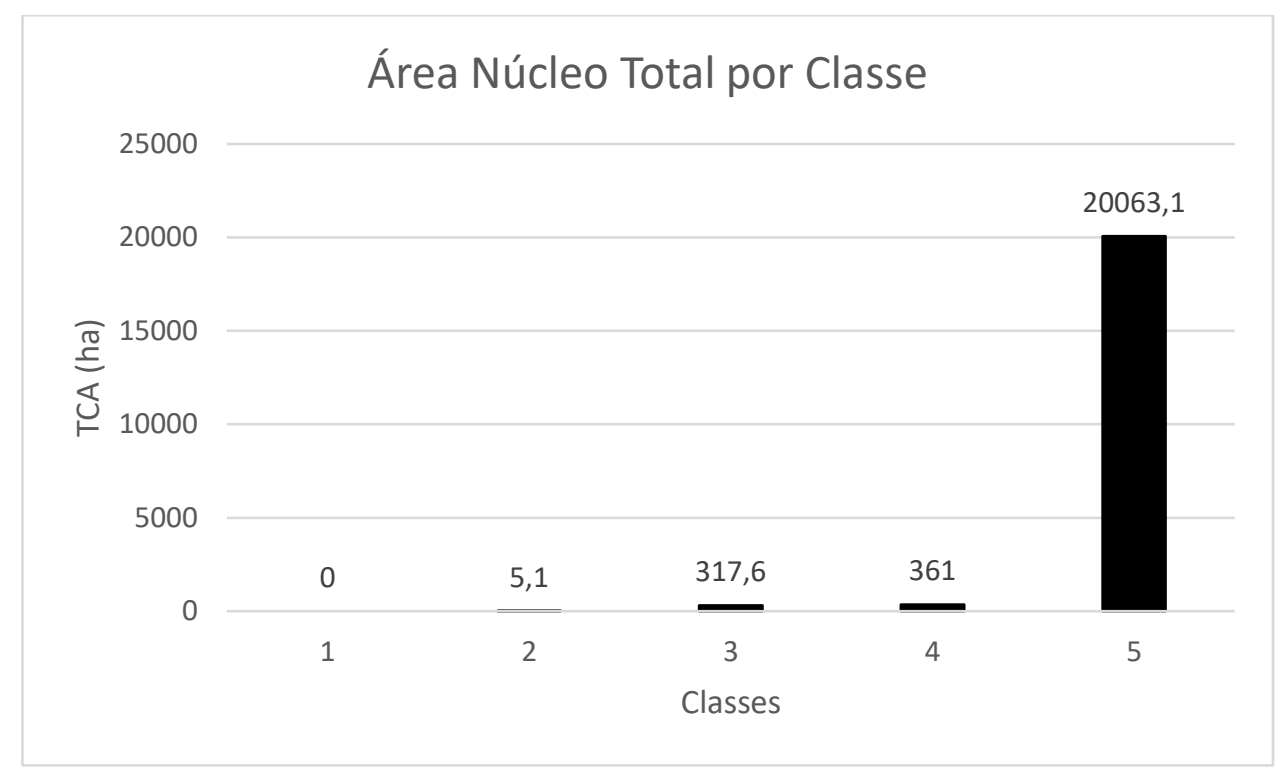

Figura 30. Gráfico de Área Núcleo Total por Classe.

Fonte: Autora

\section{3 .7}

Área das Classes vs. Área protegida pela LPVN

Quando analisado a soma total de área em cada classe de fragmento por soma total das áreas protegidas pela Lei de Proteção da Vegetação Nativa (APP Hídricas, APP de Relevo e Reservas Legais) temos a classe 1 e 4 como as mais protegidas, visto que $45 \%$ de suas áreas possui alguma APP ou Reserva Legal. A classe 5 é a menos protegida com $38 \%$ da sua área estando dentro de alguma das leis de proteção da LPVN. 


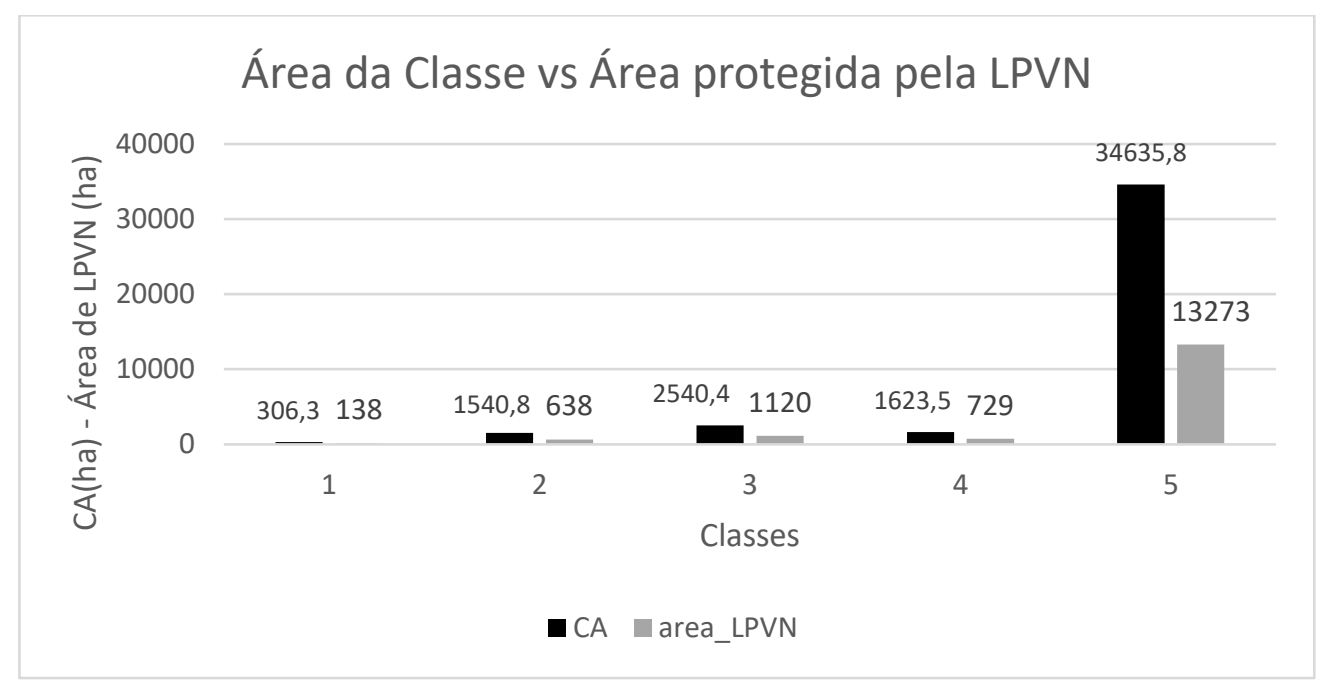

Figura 31. Gráfico de Área da Classe vs Área protegida pela LPVN. Fonte: Autora

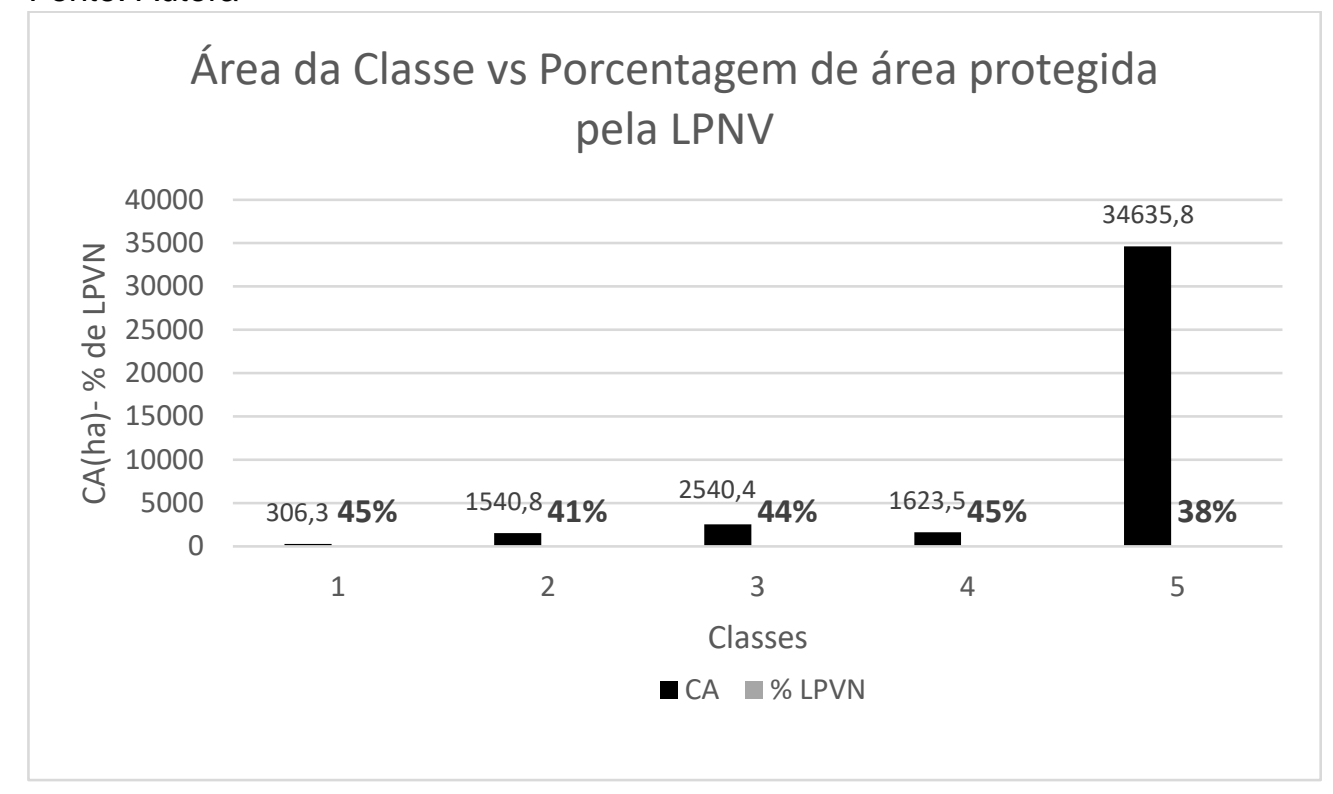

Figura 32. Gráfico de Área da Classe vs Porcentagem de área protegida pela LPNV. Fonte: Autora

\section{4 \\ Matriz de correlação}

Quando interpretamos as tabelas de matriz de correlação entre as variáveis percebemos que, quanto maior for o círculo, maior é a correlação entre as variáveis. E quanto maior mais escuro for o azul, mais próximo a correlação será de 1, sendo uma relação positiva. $\mathrm{O}$ mesmo vale ao vermelho, que quanto mais escuro mais próximo sua relação ao -1 , sendo negativa (Rocha, 2018). 
As variáveis Densidade de Borda (ED) e Número de Fragmentos (NP) só estabelecem uma relação positiva entre si. O Número de Fragmentos em negativo com as demais variáveis ocorre porque as classes que apresenta maior e menor número de fragmentos são inversamente numéricas aos seus dados gerados nas métricas de paisagem. Já a Densidade de Borda contrariamente proporcional a sua área total de fragmentos, indo em oposição aos demais resultados gerados nas métricas aplicadas. Ou seja, tanto Densidade de Borda quanto Número de fragmentos possuem seus resultados numericamente decrescentes por classe em relação aos demais.

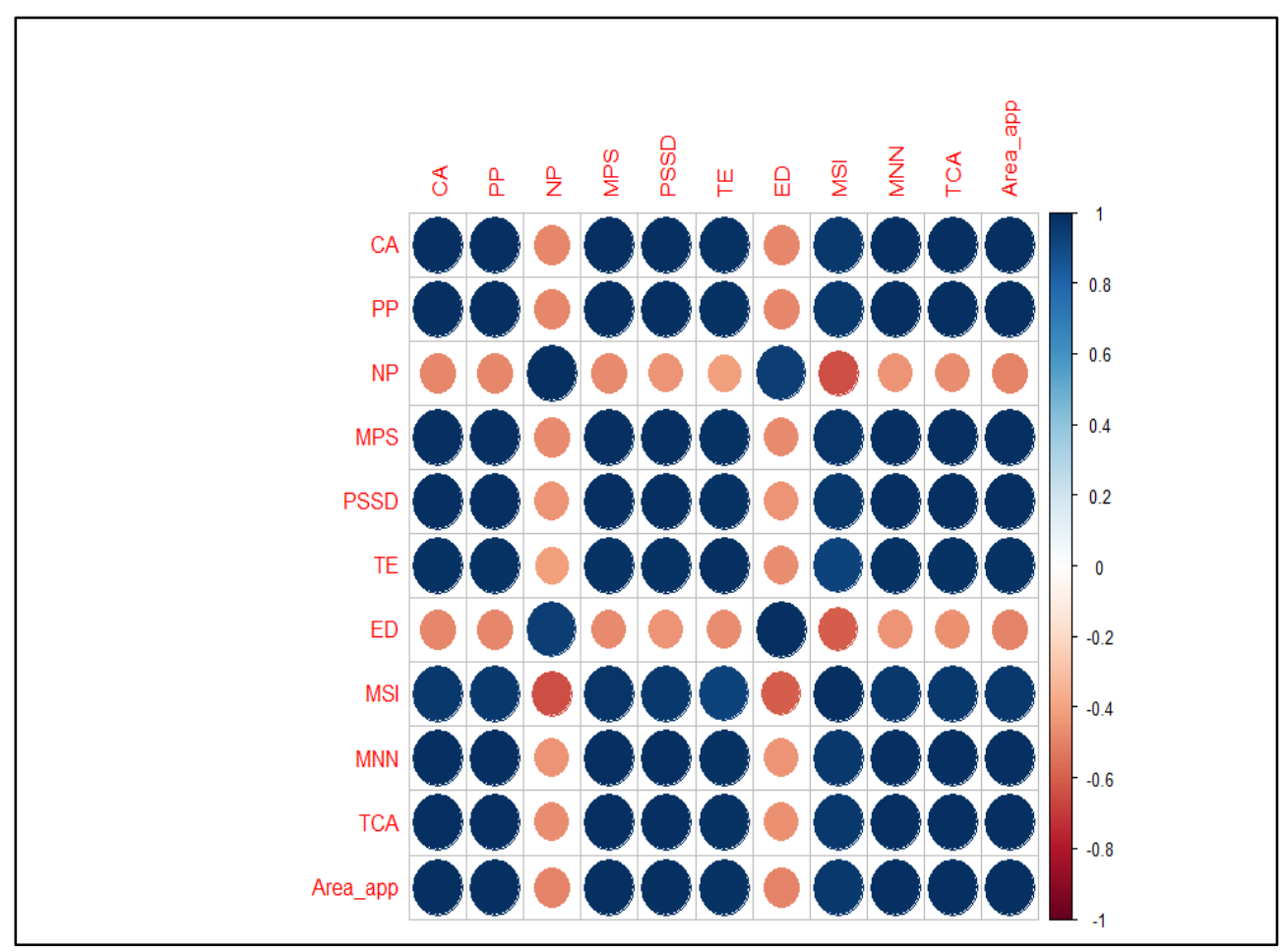

Figura 33. Matriz de Correlação gerada por cor e tamanho.

Fonte: Autora

Quando interpretado de forma numérica temos:

0.9 para mais ou para menos indica uma correlação muito forte.

0.7 a 0.9 positivo ou negativo indica uma correlação forte.

0.5 a 0.7 positivo ou negativo indica uma correlação moderada.

0.3 a 0.5 positivo ou negativo indica uma correlação fraca.

0 a 0.3 positivo ou negativo indica uma correlação desprezível. (Rocha, 2018) 
Sendo assim, a variável Densidade de Borda (ED) e Número de Fragmentos (NP) estabelece relações muito forte entre si, positivo. Moderada negativo com o Índice de Forma (MSI) e fraca negativo com as demais. As demais variáveis apresentam uma correlação muito forte positivamente.

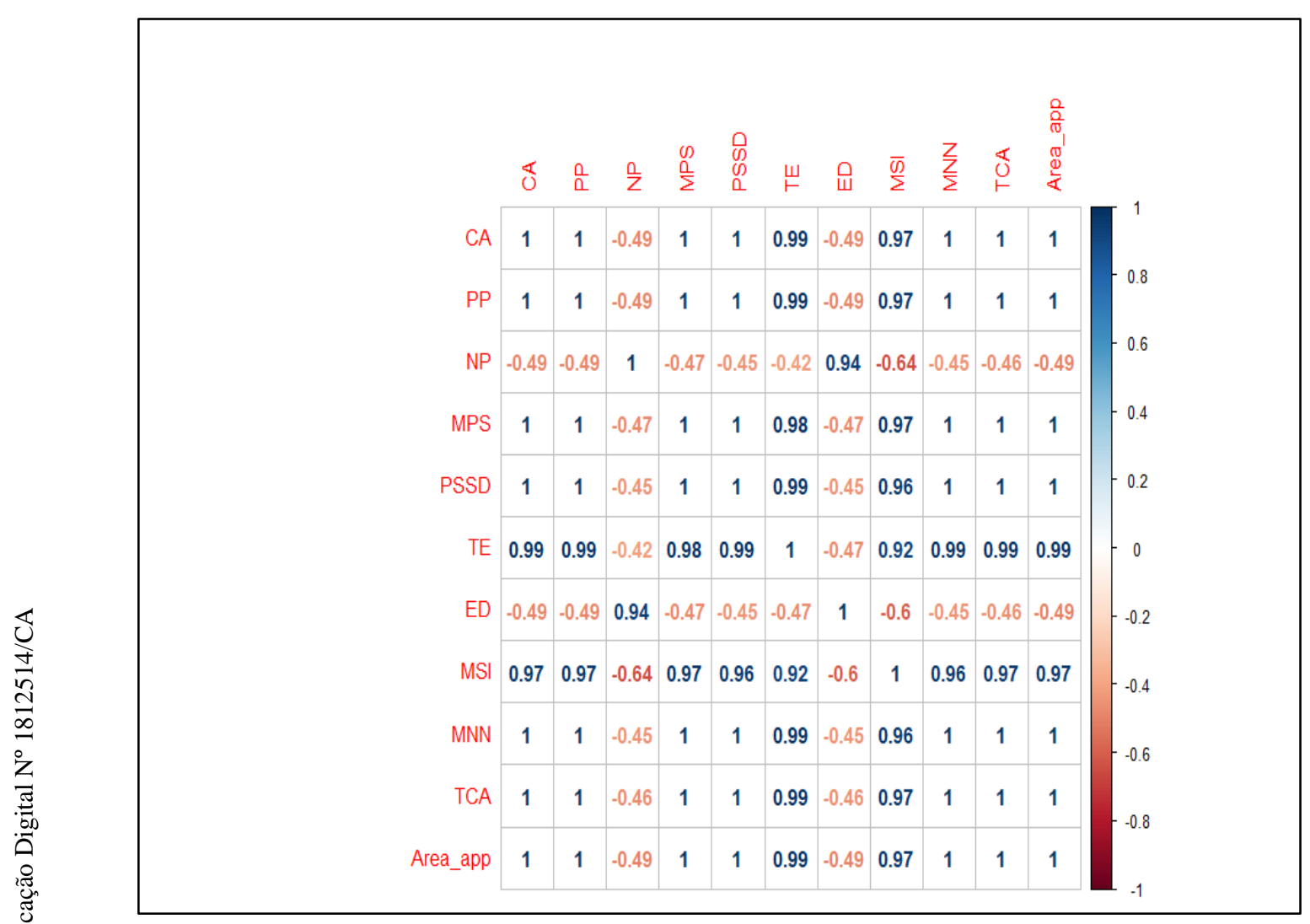

Figura 34. Matriz de correlação com a escala numérica de compatibilidade.

Fonte: Autora

\section{5}

\section{Considerações Finais}

Quando analisamos os gráficos da Figura 20, Figura 22 e Figura 23, podemos dar destaque para as métricas de área, densidade e tamanho mostrando ser importantes para traçar a distribuição por tamanhos dos fragmentos na paisagem. A métrica de densidade de borda foi importante para entender quais os fragmentos com maior potencial para conservação. A métrica de vizinho mais próximo para identificar os fragmentos com maior potencial de conectividade para criação de corredores ecológicos. 
As análises das métricas aplicadas aos fragmentos dentro da paisagem de Silva Jardim dialogando com os autores (MacArthur e Wilson,1967; McGarigal e Marks, 1994; Ranta, 1998; Ribeiro, 2008) mostra que a Classe 1 dos muito pequenos apresenta um número grande de exemplares, porém seu processo de fragmentação foi intenso os tornando isolados, com menores riquezas de biodiversidade e mais propícios a invasões de espécies negativas. Já a Classe 5 vai apresentar um número de fragmentos menores, porém ao analisar o conjunto das métricas se mostra a classe mais conservada e mais apta a criação de corredores ecológicos, pois seu efeito de borda são menos sentidos e sua conectividade maior com seus vizinhos mais próximos.

Ao juntar os fragmentos com a espacialização da LPNV temos a Figura 35.

Em analisar a figura peço atenção as classes muito pequena e muito grande, onde vemos os processos de fragmentos bem distintos, além claro, do tamanho, mas de sua disposição pelo espaço. 


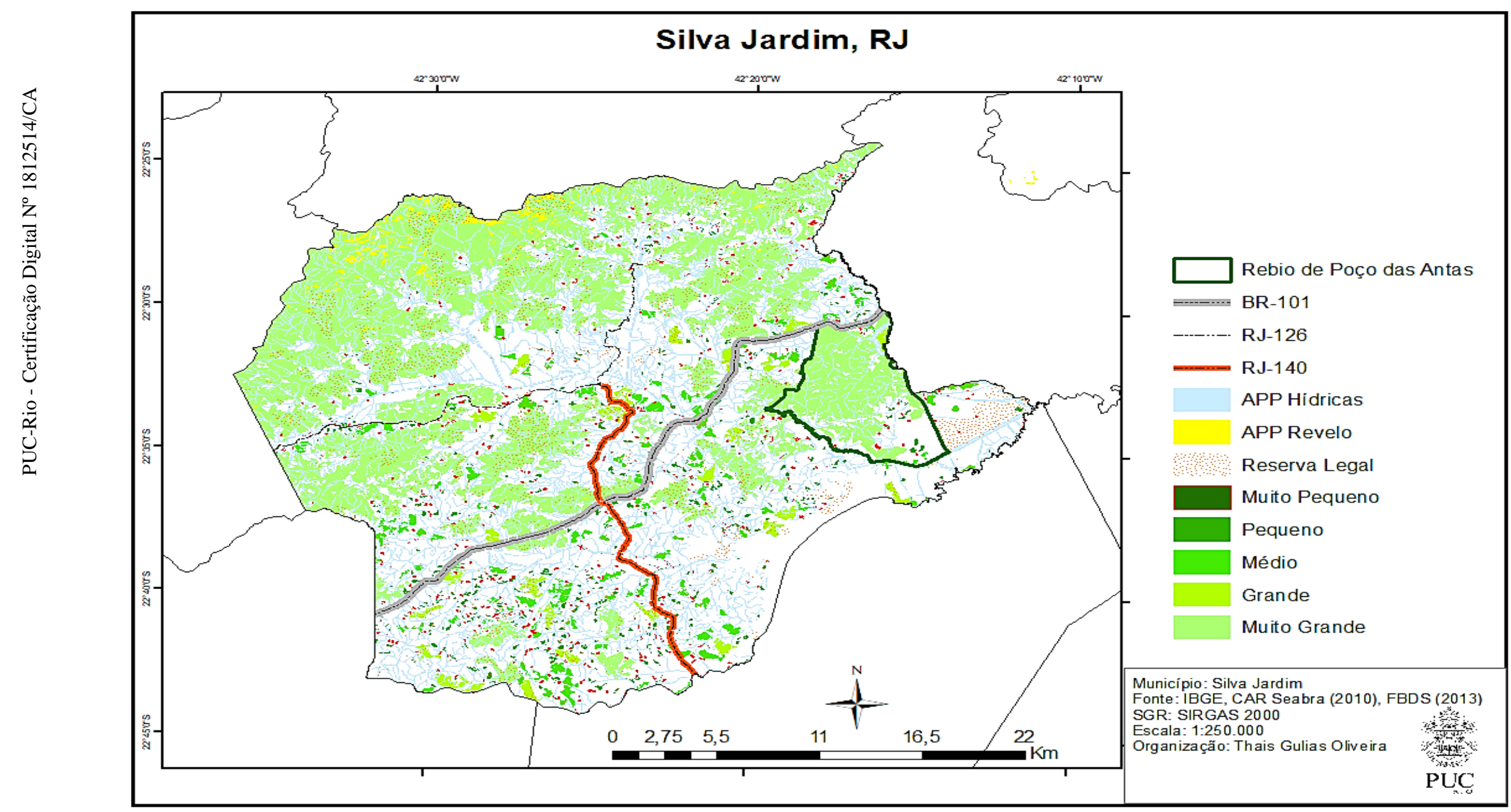

Figura 35. Espacialização das classes de fragmento e áreas protegidas pela LPVN. Fonte: Autora 
A classe 5 possui seus fragmentos mais conectados e conservados devido ao seu tamanho por estarem em áreas de maior declividade, distantes da BR-101 e uma parte dessa se encontrar dentro da REBIO de Poço das Antas. A classes 1 possui os fragmentos mais distribuídos e segmentada por todo território, em sua maioria, estão localizadas ao longo dos corpos d'água, provavelmente sendo áreas de mata ciliar, fundo de vale e pastagem, mais ligadas aos processos de ocupação (Seabra, 2015; Peixoto e Costa Junior, 2004; Abreu, 1994). Sendo assim, a LPNV, mesmo que aplicada de forma eficiente, ainda conta com os fatores históricos e geográficos de ocupação da área, no processo de fragmentação e da sua conservação. Abdalla (2015) pontua que a distribuição dos pequenos fragmentos por toda paisagem é necessária porque formam pontes para a circulação de espécies entre os fragmentos maiores. Porém, MacArthur e Wilson (1967) e Ribeiro (2008) dizem que os pequenos fragmentos sem vizinho mais próximos são aptos a desaparecerem.

Sendo assim, quando juntamos a aplicação das métricas com as Leis de Proteção a Vegetação Nativa, temos eficiência para conservação dos fragmentos de Silva Jardim nas Áreas de Preservação Permanente de Topo de Morro, linhas de cumeada e encostas, além das áreas dentro das Unidades de Conservação protegidas pelo Sistema Nacional de Unidade de Conservação da Natureza (SNUC) que surgiu de uma demanda de proteção de parques e florestas nacionais existente no Código Florestal de 1934 (Filho, 2015).

A realização dessa análise, neste recorte geográfico, encontrou dois pontos limitadores, esses pontos refletem o obstáculo que desafiam gestores e tomadores de decisão ao fiscalizarem a aplicação da LPVN. Os limitadores foram o CAR, por ser autodeclarado e as informações sobre as propriedades serem restritas contamos com a idoneidade da declaração dos proprietários ao registrar a delimitação de sua propriedade e dos $20 \%$ dela destinado a proteção da Mata Atlântica nelas. O objetivo inicial do CAR é auxiliar no planejamento ambiental e econômico, controle, monitoramentos e recuperação de áreas degradadas em espaços rurais, mas é necessário o treinamento e fiscalização na inserção dos dados (Issi et al. 2018). Apesar do CAR ser auto declarado se usarmos o em conjunto com o mapeamento de cobertura e uso das áreas, do cenário atual, teremos um resultado 
mais fidedigno. Isso se aplica quando juntamos ambos nas análises das métricas de proximidade que indica a dificuldade de conexão dos fragmentos.

O outro fator limitador é a conexão dos fragmentos ao longo dos cursos d'água. Apesar da Lei de Proteção a Vegetação Nativa identificar a proteção de APP dentro de zonas urbanas temos os conflitos de ocupação, construção imobiliária, e obras de infraestrutura urbana que leva a riscos de danos irreparáveis e permanentes no processo de fragmentação e conservação das APP's. A proteção de APP dentro de zonas urbanas e rurais visa preservar e proteger o meio ambiente, mas também eliminar, ou pelo menos diminuir, os riscos de problemas e catástrofes, como inundações, enchentes e deslizamentos (Filho, 2015).

Os resultados apresentados nessa pesquisa identificaram a potencialidade de aplicação das métricas de paisagem em mapas de cobertura e uso, identificando áreas para conservação de acordo com os critérios adotados pelo gestor, além de uma tabela de informações de matérias e métodos necessários para especializar a Lei de Proteção a Vegetação Nativa. A validação do objetivo dessa pesquisa aumenta a coerência da espacialização de áreas protegidas ou fragmentadas, no uso de políticas públicas que visão fiscalização/tomada de decisões sobre do código florestal, legislações ambientais ou planejamento/gestão ambiental. Sendo assim, o objetivo central dessa pesquisa que foi testar por meio de modelagem o potencial de conservação dos fragmentos pela Lei de Proteção da Vegetação Nativa foi alcançado por meio da metodologia desenvolvida e aplicada. 


\section{Conclusão}

O presente trabalho visou avaliar o potencial de conservação a partir da integração da análise dos fragmentos florestais e da Lei de Proteção da Vegetação Nativa- LPVN (Lei 12.651/12) dentro da bacia do Rio São João, utilizando o município de Silva Jardim como recorte. O levantamento bibliográfico e a seleção dos dados nos levaram a identificar os principais elementos da paisagem para atingir esse objetivo.

Os resultados obtidos na espacialização do código florestal nos indicam que 33,2\% da área total do município se encontra resguardada pela Lei da Proteção a Vegetação Nativa, porém sua maioria está dentro de propriedades rurais. A maioria dessas áreas está ligada as Áreas de proteção permanentes de cursos d'água e as menores áreas protegidas são as de relevo. Além disso, as áreas destinadas as Reservas Legais são autodeclaradas no sistema da CAR, levantando algumas dúvidas sobre a veracidade desse dado.

Quando falamos dos dados do CAR, deveriam ser analisados com maior cuidado pelo poder público e assim liberados de forma gratuita. Além disso, alguns dados não são disponibilizados no CAR, como a licença de produção de cada imóvel. Contudo, a espacialização da LPVN feita aqui é bem útil quando identificamos cada dado escolhido e ferramenta utilizada, sendo um guia para a interpretação da lei.

Ao realizar as análises dos 1402 fragmentos mapeados pelo FBDS, os dividimos por classes de tamanho sendo a Classe 1 de fragmentos muito pequenos, possuindo 724 fragmentos e o total de 306, 37 ha. A Classe 2 de pequenos, possuindo 511 fragmentos e 1540,8 ha. A Classe 3 de médios, possuindo 116 fragmentos e 2540,4 ha. A Classe 4 de grandes, 26 fragmentos e 1623,5 ha. A Classe 5 de fragmentos muito grandes, 25 fragmentos e 34635,8 ha.

O uso do V-Late para calcular as métricas da paisagem foi bem intuitivo, e didático devido a sua interface, e manual. Com a aplicação das métricas nas classes nos chamam a atenção são as classes 1 e 2 , relativas aos menores 
fragmentos, correspondendo $88 \%$ do total dos fragmentos. Segundo Ranta (1998), McGarigal e Marks (1994), Ribeiro (2008) os fragmentos pequenos são os mais delicados por estarem mais vulneráveis aos efeitos externos e internos sobre eles. E a classe 5 que mesmo correspondendo a menor número de fragmentos é a maior em porção territorial.

Quando realizamos análise conjunta das classes de fragmentos e as áreas protegidas pela LPVN temos as classes muito pequenas e a grande como as mais protegidas, tendo $45 \%$ de suas áreas inseridas dentro de alguma APP ou RL. Isso ocorre porque as manchas citadas são as mais distribuídas pela paisagem, principalmente ao longo das proximidades dos corpos d'água das áreas planas, onde sofreram maior ocupação histórica. Abdalla (2015) indica que elas podem ser vistas como uma área de passagem para as espécies circularem entre os maiores fragmentos.

A utilização da matriz de correlação no RStudio foi a metodologia utilizada para confirmar de forma estatística se há alguma relação entre os dados analisados. Apesar de necessário o entendimento básico de programação ao utilizar a linguagem R, após entender as variáveis da formula, sua aplicação é bem simples. Esse sistema provou que as variáveis selecionadas para compreensão da fragmentação da paisagem têm uma relação positiva, ou seja, foram uma escolha eficiente.

Quando falamos da eficiência da aplicação da LPNV para conservação da paisagem de Silva Jardim dentro da Bacia do Rio São João, não podemos anular seu processo de histórico de ocupação, pois, como apontado, as áreas mais fragmentadas estão nos limites de APP de curso d'água em áreas planas, o que indica áreas de mata ciliar, fundo de vale mais procurado para ocupação urbana e áreas de pastagem ou cultivo. A classe apontada como muito grande e apontada como a menos protegida pela LPNV está inserida nas áreas menos ocupadas por apresentarem alta declividade e distanciamento da BR- 101 (Seabra, 2015; Peixoto e Costa Junior, 2004; Abreu, 1994).

Como observado as áreas mais protegidas são aquelas com menor perturbação antrópica, nesse sentido como sugere Capra (2003) e Gonçalves (2002) é muito importante a alfabetização ecológica, compreensão dos princípios de organização do ecossistema e a busca por projetos ecológicos, 
que reformulam fundamentalmente as técnicas e prezar pela participação social.

Em futuros estudos sugere-se aplicação da metodologia em toda a bacia, avaliando os oito municípios, indo além de apenas seu entendimento na preservação da bacia pelas leis de gestão como avaliado no item 5.1.1 mas avaliar como encontra seu grau de conservação florestal somado a aplicação da Lei de Proteção a Vegetação Permanente, além de realizar uma análise temporal comparativa dos últimos cinco anos, comparando se é avanços ou não da fragmentação com a aplicação da lei. 
Referências Bibliográficas

AB'SÁBER, A. Os domínios de natureza no Brasil: Potencialidades Paisagísticas. São Paulo: Ateliê Editorial. 2003.

ABDALLA L. S. \& CRUZ C. B. M .Análise de fragmentação florestal no município de Silva Jardim. Revista Brasileira de Cartografia, Rio de Janeiro, N0 67/1. 2015. P. 169-184.

ABREU, A. I. C. Municípios e topônimos fluminenses: história e memória. Niterói: Imprensa Oficial Do Estado Do Rio De Janeiro, 1994.

AHAMED, T.; TIAN, L.; ZHANG, Y; TING, K. C. A review of remote sensing methods for biomass feedstock production. Biomass And Bioenergy, V. 35. 2011. P. 2455-2469.

AHRENS, S. O instituto jurídico da Reserva (Ambiental) Legal: conceito, evolução e perspectivas. Monografia (Bacharelado em Direito) - Centro de Ciências Jurídicas e Sociais, PUC-PR, Curitiba. 2001. 59 p.

ALGER, K.; LIMA, A. Políticas públicas e a fragmentação de ecossistemas. In: Fragmentação de ecossistemas: causas e efeitos sobre a biodiversidade e recomendações de políticas públicas. MMA/SBF. Brasília. 2003.

AMADO, F. Direito Ambiental Esquematizado. Legislação de Direito Ambiental. 4.Ed. São Paulo: Método, Brasil.2013.

ANDRADE, L.S. Avaliação de fragmentos florestais em uma região do quadrilátero ferrífero: municípios de Mariana e Ouro Preto. Enciclopédia Biosfera, Centro Científico Conhecer - Goiânia, V.8, N.14. 2012.

BENJAMIN. A.V.H. Ascensão e queda da Lei de Proteção da Vegetação Nativa. In. Congresso Internacional de Direitos Ambiental, 4: Agricultura e Meio Ambiente. Anais. São Paulo: Promotoria de justiça de meio ambiente. O direito por um planeta verde. São Paulo.2000

BERGALLO, H. G.. Estratégias e ações para a conservação da biodiversidade no estado do Rio de Janeiro. Rio de Janeiro: Instituto Biomas.2009.

BERTRAND, G. Paisagem e geografia física global: esboço metodológico. Cadernos de Ciências da Terra, São Paulo: Instituto de Geografia da USP, n. 13. 1972.

BESSE, J. M. As cinco portas da paisagem - ensaio de uma cartografia das problemáticas contemporâneas. In: BESSE, Jean-Marc. O gosto do mundo. Exercícios de paisagem. Rio de Janeiro: Editora da Universidade do Estado do Rio de Janeiro. 2014. 
BESSE, J. M. Entre a geografia e a ética: a paisagem e a questão do bem-estar. Trad. Eliane Kuvasney e Mônica Balestrin Nunes. GEOUSP Espaço e Tempo. São Paulo v. 18 n. 2014.p. 241-252.

BIDEGAIN, P.; PEREIRA, L.F.M. Plano das bacias hidrográficas da região dos lagos e do Rio São João. Rio De Janeiro: CILSJ. 2005.

BIDEGAIN, P.; VOLCHER, C.M. Bacia hidrográfica do Rio São João e das Ostras: águas, terras e conservação ambiental. Rio De Janeiro. Consórcio intermunicipal para a gestão das bacias da Região dos Lagos, Rio São João e Zona Costeira. Rio De Janeiro. 2003.

BRASIL. Conselho Nacional do Meio Ambiente. Resolução N.001, De 23 De Janeiro de 1986. Dispõe sobre critérios básicos e diretrizes gerais para o relatório de impacto ambiental - Rima. Diário Oficial [Da] República Federativa Do Brasil, Brasília, DF, 17 Fev. 1986.

BRASIL. Lei № 12.651, De 25 de maio de 2012. Institui A Novo Lei de Proteção da Vegetação Nativa Brasileiro. 2012.

BRASIL. Lei Orgânica Municipal De Silva Jardim De 05 de abril de 1990.Câmara Municipal De Silva Jardim. Estado Do Rio De Janeiro. Brasil. 1990

BRASIL. Senado Federal. Lei de Proteção da Vegetação Nativa De 1934. DF, $\quad 1934 . \quad$ Disponível Em: <http://www.senado.gov.br/noticias/jornal/emdiscussao/codigo-florestal/senado-oferece-umprojeto-equilibrado-para-o-novo-codigo-florestal-brasileiro/codigo-florestalde-1934.aspx>. Acessado em 26 de abril de 2020

BRASIL. Senado Federal. Evolução Da Lei Ambiental Brasileira. Brasília, $2012 . \quad$ Disponível Em: <http:// www.senado.gov.br/noticias/jornal/emdiscussao/codigo-florestal/senadooferece-um-projeto-equilibrado-para-o-novo-codigo-florestalbrasileiro/evolucao-da-lei-ambiental-brasileira.aspx>. Acessado em 26 de abril de 2020

BURROUGH, P. A. Principles of geographic information systems for land resources assessment. Oxford, Oxford University Press. 1986.

CABRAL, D. $O$ 'Bosque de Madeiras' e outras histórias: A Mata Atlântica no Brasil Colonial (Séculos XVIII e XIX). Tese de DoutoradaUFRJ. Rio De Janeiro. 2012. 246p.

CABRAL, D; CESCO, S. Notas para uma história da exploração madeireira na Mata Atlântica do Sul-Sudeste Ambiente \& Sociedade, Vol. XI, Núm. 1, Janeiro-Junho. Campinas. 2008.

CÂMARA, G., DAVIS.C, A.M E J.C. D'alge. Introdução à ciência da geoinformação. São José Dos Campos, INPE. 2001. Disponível Em: $>$ www.dpi.inpe.br/gilberto/livro_< Acessado em 26 de abril de 2020

CAPRA, F. As Conexões Ocultas: Ciência Para Uma Vida Sustentável. 3 Ed. São Paulo. 2003. 
CARVALHO, F.A.; NASCIMENTO, M.T.; PROCÓPIO DE OLIVEIRA, P.; RAMBALDI, D.M. \& FERNANDES, R.V. A importância dos remanescentes florestais da Mata Atlântica de baixada costeira fluminense para a conservação da biodiversidade na APA da Bacia do Rio São João/mico-leão-dourado - RJ.In: Anais Do IV Congresso Brasileiro De Unidades De Conservação, V.1. Curitiba, Fundação O Boticário De Proteção À Natureza: Rede Nacional Pró Unidades De Conservação. 2004.

COE, H. Peculiaridades ecológicas da região de Cabo Frio, RJ. Julho/ Dezembro-Ano Iv, №. 2. 2007.

CONSÓRCIO INTERMUNICIPAL LAGOS SÃO JOÃO. Relatório final da oficina "a bacia hidrográfica da região dos lagos e do Rio São João frente aos desafios da mudança climática, e os impactos sobre os recursos naturais, especialmente os recursos hídricos". Araruama. 2009.

COORDENAÇÃO DE PROJETOS, PESQUISAS E ESTUDOS TECNOLÓGICOS - COPPETEC. Elaboração do plano estadual de recursos hídricos do estado do Rio de Janeiro. SEA E INEA. 2014.

COSGROVE, D. John Ruskin and the geographical imagination. Geographical Review. 1979. 69p.

COSGROVE, D. Social formation and symbolic landscape. Londres: Croom Helm. 1984.

COSGROVE, D. Prospect, perspective and the evolution of landscape idea. Transactions of the Institute of British Geographers. 1985.

COSGROVE, D. Mapping new worlds: culture and cartography in sixteenth century Venice. Imago Mundi. 1992. 14p.

COSGROVE, D. The palladian landscape. Geographical change and its cultural representations in sixteenth century Italy. University Park, Pennsylvania State University Press. 1993.

COSGROVE, D. A geografia está em toda parte: cultura e simbolismo nas paisagens humanas. In: Paisagem, Tempo e Cultura. CORRÊA, R.L.; ROSENDAHL, Z. (orgs.). Rio de Janeiro: EDUERJ. 1998.

COSGROVE, D. Mundos de significados. Geografia cultural e imaginação. In: Geografia Cultural: Um Século (2). CORRÊA, R.L.; ROSENDAHL, Z. (orgs.). Rio de Janeiro: EDUERJ. 2000.

COSGROVE, D. Appolo's eye. A cartography genealogy of the earth in the western imagination. Baltimore: Johns Hopkins University Press, 2001.

COSGROVE, D. Modernity, community and the landscape idea. Journal of Material Culture. 2006.

COSGROVE, D. Renaissance cosmography - 1450-1650. In: The History of Cartography. V. 1 - Renaissance Cartography. WOODWARD, D. (org.). Chicago: The University of Chicago Press. 2007 
COSTA, R.L., PREVEDELLO, J.A., DE SOUZA, B.G., CABRAL, D.C. 2017 Forest Transitions Intropical Landscapes: A test in the Atlantic Forest Biodiversity hotspot. Appl. Geogr. 82. 2017.p. 93-100.

COUTINHO, L.M. Mapeamento de uso do solo e áreas de conservação permanente (APP) na bacia do córrego Itabira, Cachoeiro de Itapemirim-ES. P. 35 -42. Anais XVII Simpósio Brasileiro de Sensoriamento Remoto - Sbsr, João Pessoa-PB. 2015.P. 35 -42.

COUTO, J.L.V.. Fragmentos Florestais. Rede Agronomia, Rede Dos Engenheiros Agrônomos do Brasil. 2017. Disponível Em: $<$ http://agronomos.ning.com/profiles/blogs/fragmentos-

florestais?id=3071024\%3ablogpost\%3a299076\&page=3 $>$ Acessado em 26 de abril de 2020

CROUZEILLES et al. Deslocamento na matriz para espécies da Mata Atlântica e a dificuldade da construção de perfis ecológicos. Oecologia Australis. Dezembro.2010. p.872-900.

CUNHA, S. B.; GUERRA, A. J. T (orgs.). A questão ambiental: diferentes abordagens. Rio De Janeiro: Bertrand Brasil. 2003

DEAN, W. A Ferro E Fogo: A história e a devastação da Mata Atlântica Brasileira. 1. Ed. São Paulo: Cia. Das Letras. 2004.

DUARTE, L; NEVES, N. Modelação geográfica de métricas de paisagem: efeito de escala e efeito de contexto. Cadernos de Geografla. Colmbra, FLUC. Portugal. 2008. p. 255-268.

EMPRESA BRASILEIRA DE PESQUISA AGROPECUÁRIA - EMBRAPA. Módulos Fiscal. 2019. Disponível Em: >https://www.embrapa.br/codigoflorestal/area-de-reserva-legal-arl/modulo-fiscal.< Acessado em 26 de abril de 2020

FILHO, A.O; RAMOS, J. M; OLIVEIRA, K; NASCIMENTO, T. A evolução da Lei de Proteção da Vegetação Nativa Brasileiro. Ciências Humanas E Sociais Unit . Aracaju. V. 2 | N.3 . Março. 2015. P. 271-290.

FONSECA, G. A. B., K. ALGER, L. P. PINTO, M. ARAÚJO \& R. CAVALCANTI. Corredores de Biodiversidade: o corredor central da Mata Atlântica. In Arruda, M. B. \& L. F.S. N. Sá (Orgs.). Corredores Ecológicos: Uma Abordagem Integradora De Ecossistemas no Brasil. Ibama. Brasília.2004. Pp. 47-65.

FONSECA, G. A. B., L. P. PINTO \& A. B. RYLANDS. Biodiversidade e Unidades de Conservação. In Anais do I Congresso Brasileiro de Unidades de Conservação,Conferências e Palestras. Universidade Livre do Meio Ambiente, Rede Pró-Unidades de Conservação e Instituto Ambiental do Paraná, Curitiba, 1997. p. 189-209

FORMAN, R. T. T. Land Mosaics: The ecology of landscapes and regions. London: Cambridge University Press. 1995. 
FRANKE, C.R; ROCHA, P; KLEIN, W; GOMES, S. Mata Atlântica e Biodiversidade. Editora da UFBA. Salvador, 2005.

FUNDAÇÃO SOS MATA ATLÂNTICA \& INPE. Atlas dos remanescentes florestais da Mata Atlântica e ecossistemas associados no período de 1995-2000. Relatório Final. São Paulo, 2002.

GASCON, C. et all. Matrix Habitat And Species Persistence In Tropical Forest Remnants. Biological Conservation 91. 1999.

GUSTAFSON, E. "Quantifying landscape spatial pattern: What is the state of the art?". Ecosystems, val. 1. 1998. p. 143- 156.

GAVIOLI, F.R. O impacto da Lei Florestal Brasileira na instituição de reservas legais no território paulista: um estudo a partir dos dados públicos do sistema de Cadastro Ambiental Rural. Revista Desenvolv. Meio Ambiente, V. 42. Dezembro,2017. P. 160-179.

GONÇALVES, C. W. P. formação sócio-espacial e questão ambiental no Brasil. In: Becker, Berta et all. (orgs.). Geografia e meio ambiente no Brasil. 3" Ed. São Paulo: Hucitec.2002.

GRAY, M. Landscape: The physical layer. In HOLLOWAY, Sarah L., RICE, Stephen P., VALENTINE, Gill (Eds.). Key Concepts in Geography. 6 ed. London: Sage.2007. 342p.

GREGOLETI, A.M; MORO, N; SANTOS, C.F. Mata Atlântica: a primeira impressão de uma visão européia. VIII CIH. 2017. P. 866 - 871.

GUERRA, A.; BATISTA, S.(orgs.) Geomorfologia: Uma atualização de bases e conceitos. Editora Bertrand Brasil. 1996.

GUERRA, A. Dicionário Geológico-Geomorfológico. 7 Ed. Rio de Janeiro: IBGE. 1989

HILTY JA, LIDICKER WZ JR, MERENLENDER AM. Corridor Ecology: the Science and Practice of Linking Landscapes for Biodiversity Conservation. Washington, DC: Island Press, 2006.

INSTITUTO BRASILEIRO DO MEIO AMBIENTE E DOS RECURSOS NATURAIS RENOVÁVEIS- IBAMA. Unidades de conservação do Brasil, Vol. 1 - Parques Nacionais e Reservas Biológicas. Brasília,1989.

INSTITUTO BRASILEIRO DE GEOGRAFIA E ESTATÍSTICA- IBGE. Censo 2010. Rio de Janeiro.2010.

INSTITUTO BRASILEIRO DE GEOGRAFIA E ESTATÍSTICA- IBGE. Indicadores de desenvolvimento sustentável. Diretoria de geociências. Rio de Janeiro. 2002.

INSTITUTO BRASILEIRO DE GEOGRAFIA E ESTATÍSTICA- IBGE. Silva Jardim. Enciclopédia dos municípios brasileiros, Vol 22. Rio De Janeiro.2010.

INSTITUTO CHICO MENDES DE CONSERVAÇÃO DA BIODIVERSIDADE- ICMBIO. . Plano De Ação Do Mosaico Do 
Mico- Leão- Dourado Brasil. Brasilia, 2011. Disponível Em: $>$ www.icmbio.gov.br/portal/images/stories/mosaicos/plano-mico-leao.pdf<

INSTITUTO CHICO MENDES DE CONSERVAÇÃO DA BIODIVERSIDADE- ICMBIO. Plano de manejo da Reserva Biológica de Poço das Antas. Brasil, 2005. Disponível em: $>$ http://www.icmbio.gov.br/portal/unidadesdeconservacao/biomasbrasileiros/mataAtlântica/unidades-de-conservacao-mata-Atlântica/2155rebio-de-poco-das-antas< Acessado em 26 de abril de 2020

INSTITUTO CHICO MENDES DE CONSERVAÇÃO DA BIODIVERSIDADE- ICMBIO. Plano de manejo da área de proteção ambiental da Bacia do Rio São João/Mico-Leão-Dourado. Brasília: MMA.2008

ISSI, T.M; SALVADOR, C.S.Z.; COSTA, A.A.D.; NEVES,S.M.A.S.; HARDT,E. 2018. Desafios na espacialização da Lei de Proteção da Vegetação Nativa (Lei 12651/12) na bacia do Alto Paraguai. Anais $7^{\circ}$ Simpósio De Geotecnologias No Pantanal, Jardim, MS.2018.P. 170-179.

LANG, S.; BLASCHKE, T. Análise da paisagem com SIG. Tradução De Hermman Kux. Ed. Oficina De Textos. 2009.

LANG, T. VLATE Extension für ArcGIS - vektorbasiertes Tool zur quantitativen Landschaftsstrukturanalyse - ESRI European User. 2003.

LAXE, J. B. C. Regimento das câmaras municipais ou Lei de $1^{\circ}$ de outubro de 1828. E. \& H. Laemmert. Rio de Janeiro. 1868.

LEVY, M. B. A. Indústria do Rio de Janeiro através de suas sociedades anónimas. Rio De Janeiro, Editora UFRJ/Secretaria Municipal De Cultura. 1994.

LOBO, M L C. A sinergia entre os planos de bacias hidrográficas e os planos diretores municipais: uma abordagem metodológica / Mirna Luiza Cortopassi Lobo (org.) - Curitiba, 2014.

LOPES, E. R. N.; REUSS-STRENZEL, G. M. Geoprocessamento aplicado ao monitoramento da ocupação de unidades de conservação - um olhar sobre a área de proteção ambiental de Guaibim. Revista de Geografia (UFPE), V. 32, N. 3. 2015. p. 43-59.

MACARTHUR, R. H., AND E. O. WILSON. The theory of island biogeography. Princeton, Nj: Princeton University Press. 1967.

MCGARIGAL, K., MARKS, B. J. Fragstats: Spatial pattern analysis program for quantifying landscape structure. Version.2.0 Mar 1994.

MELO, AL. Reservas particulares do patrimônio natural em Silva Jardim, Rio de Janeiro: perfil e características do manejo. Monografia. (término de curso de graduação em engenharia florestal). UFRural,RJ. Seropédica, Rio de Janeiro, 2004. 105p.

MENEZES, P. M. L.; FERNANDES, M. C. Roteiro de cartografia. Oficina De Textos. São Paulo, 2013. 
METZGER, J.P. O que é ecologia de paisagens? Biota Neotropica, Campinas, SP, v.1, n.1/2, 2001. P. 1-9.

MINISTERIO DO MEIO AMBIENTE- MMA. Áreas prioritárias para a conservação, utilização sustentável e repartição dos benefícios da biodiversidade nos biomas brasileiros. Secretaria de biodiversidade e floresta, MMA. Brasília,2002.

MINISTERIO DO MEIO AMBIENTE- MMA. Avaliação e identificação de áreas prioritárias para a conservação, utilização sustentável e repartição dos benefícios da biodiversidade dos biomas brasileiros. MMA/SBF. Brasília, 2002.

MINISTERIO DO MEIO AMBIENTE- MMA. Fragmentação de ecossistemas: causas, efeitos sobre a biodiversidade e recomendações de políticas públicas. Brasília-DF. 2003. 508p.

MINISTERIO DO MEIO AMBIENTE- MMA. Mata Atlântica: Manual de adequação ambiental / Maura Campanili E Wigold Bertoldo Schaffer (org.). - Brasília: MMA/SBF. 2010.

MINISTERIO DO MEIO AMBIENTE- MMA. Biodiversidade Brasileira Vol. 5. Avaliação e identificação de áreas e ações prioritárias para a conservação, utilização sustentável e repartição dos benefícios da biodiversidade dos biomas brasileiros. Brasília: MMA.2012.

MITTERMEIER, R. A., P. R. GIL, M. HOFFMANN, J. PILGRIM, J. BROOKS, C. G. MIITERMEIER, J.LAMOURUX \& G. A. B. FONSECA.2004. Hotspots Revisited: Earth's Biologically Richestand Most Endangered Terrestrial Ecoregions. CEMEX. Washington, DC.

MORELLATO, L.P.C. \& LEITÃO FILHO, H.F. Ecologia E Conservação De Uma Floresta Tropical Urbana: Reserva De Santa Genebra. Editora da Unicamp, Campinas, 1995.

MURCIA, C. Edge effects in fragmented forests: implications for conservation. Trends ecology and Evolution. V. 10. 1995. P.58-62.

NUNES, M. Cidades da costa brasileira - onde vive $60 \%$ da população - já sofrem com elevação do nível do mar. Conexão Planeta. 2017. Disponível em:> http://conexaoplaneta.com.br/blog/cidades-da-costabrasileira-onde-vive-60-da-populacao-ja-sofrem-com-elevacao-do-niveldo-mar-agora-so-resta-se-adaptar/< Acessado em 26 de abril de 2020

ODUM, E.P. Ecologia. Rio de Janeiro: Guanabara. 1988.

ODUM, E.P. Basic ecology. New York: Saunders, 1983.

OLIVEIRA, F. LS; MELLO, E. F .A. Mineração de areia e os impactos ambientais na Bacia do Rio São João, RJ. Revista Brasileira de Geociência, 2007.

PAESE ,A; UEZU, A.; LORINI. M.L; CUNHA, A. Conservação da biodiversidade com SIG. Oficina de Textos. São Paulo, 2012. 
PEIXOTO, G. L. \& COSTA-JÚNIOR, W. J. A rodovia BR-101 e seus impactos na Reserva Biológica União, Rio de Janeiro, Brasil. In: Anais do IV Congresso brasileiro de unidades de conservação, vol. 2. Fundação o boticário de proteção à natureza: Rede Nacional Pró Unidades de Conservação, Curitiba, 2004. p 307-315.

PIRES, V; GARCIA, M.A; MARTINES, M; TOPPA, R. Análise da estrutura da paisagem para o estabelecimento de estratégias conservacionistas em fragmentos de Mata Atlântica.I Simpósio Internacional de Águas, Solos e Geotecnologias - SASGEO. 2015.

PROCÓPIO DE OLIVEIRA, P. Conservação do mico-leão-dourado: enfrentando os desafios de uma paisagem fragmentada. Campos dos Goytacazes: Universidade Estadual do Norte Fluminense Darcy Ribeiro; Centro de biociências e biotecnologia; Laboratório de ciências ambientais. Brasil, 2008.

RANTA, P.; BLON, T.; NIEMELÃ, J.; JOENSUU, E., SIITONEN, M. The fragmented Atlantic Rain Forest of Brazil: size, shape and distribution of forest fragments. Biodiversity and Conservation V.7. 1998.P.385-403.

$R$ CORE TEAM. R: A language and environment for statistical computing. R Foundation for Statistical Computing. Vienna, Austria: 2015. Disponivel em >www.R-project.org/< Acessado em 26 de abril de 2020

RIBEIRO, M. S. L. Efeitos De Borda Sobre A Vegetação E Estruturação Populacional Em Fragmentos De Cerradão No Sudoeste Goiano, Brasil. Acta Bot. Bras. São Paulo, V. 22. 2008.p. 535-545.

RIO DE JANEIRO (Estado). Secretaria de Estado do Ambiente. Plano municipal de conservação e recuperação da Mata Atlântica de Silva Jardim / Secretaria de Estado do Ambiente ;Renata de Souza Lopes, Janete Abrahão (org.). - Rio de Janeiro, 2017. 135p.

ROSA, R. Geotecnologias na geografia aplicada. Revista do departamento de geografia, № 16. 2005. Disponível em: <http://www.geografia.fflch.usp.br/publicacoes/rdg/rdg_16/roberto_rosa.pd $f>$ Acessado em 26 de abril de 2020

ROSA, R; BRITO, J. Introdução Ao Geoprocessamento: Sistema De Informação Geográfica. Universidade Federal de Uberlândia. Brasil, 1996.

ROCHA, D. Sobre Correlações e visualizações de matrizes de correlação no R. 6 de novembro de 2018. Disponível em: <https://rstudiopubs-

static.s3.amazonaws.com/437792_df39a5ff0a55491fb71f0f4a0f5cd0bf.ht $\mathrm{ml}$ Acessado em 26 de abril de 2020

ROSS, J. L. SANCHES. Geografia do Brasil. São Paulo, SP : EDUSP, 1995.

SAINT-ADOLPHE, J. C. R. M. Diccionario geographico, historico e descriptivo, do imperio do Brazil. J. P. Aillaud. França, 1845. 
SANTOS, K. \& KINOSHITA, L. S. Flora Arbustivo-Arbórea do fragmento de floresta estacional semidecidual do Ribeirão Cachoeira, Município De Campinas, SP. Acta Bot. Bras. Vol.17 No.3 São Paulo, 2003.

SANTOS, M. A Natureza do Espaço: Técnica, razão e emoção. $3^{a}$ Edição. São Paulo: Edusp (Editora da USP), 2003.

SANTOS, N. M. Análise da influência da cobertura do solo sobre os valores das variáveis físicas da atmosfera em diferentes localidades no estado do Rio De Janeiro. Monografia de Engenharia Florestal. UFRRJ, 2009.

SAUER, C.O.The personality of Mexico. The Geographical Review, 1941. $31 \mathrm{p}$.

SAUER, C.O. Foreword the historical geography. Annals of the Association of American Geographers, 1941. 31p.

SAUER, C.O. A geographic sketah of early man in America. The Geographical Review, 1944. 34 p.

SAUER, C.O. Environmental and culture during the last glaciation. Proceedings of the American Philosophical Society, 1948. 92p.

SAUER, C.O. Homestead and community in the middle border. In: Land Use Policy in United States. OTTONSON, H. (ORG.). Lincoln: University of Nebraska Press, 1963.

SAUER, C.O. 1. Status and change in the Midwest - a Retrospect. Mitteilungen der Österreichischen Geographischen Gesellschaft, 963. 1963.105p.

SAUER, C.O. Seeds, spaces, herds and hearths. The Domestication of Animals and Foodstuffs. Cambridge: The MIT Press, 1969.

SAUER, C.O. A morfologia da paisagem. In: Paisagem, Tempo e Cultura. CORRÊA, R.L.; ROSENDAHL, Z. (ORGS.). EDUERJ. Rio de Janeiro, 1925.

SCHAFFER, W.B., \& M. PROCHNOW. A Mata Atlântica 0. APREMAVI, Brasília, 2002.

SEABRA, V. S; VICENS, R.S; CRUZ, C.B.M. Análise da paisagem e favorabilidade à recuperação florestal: um estudo na bacia hidrográfica do Rio São João. Novas Edições Academicas, RJ, 2015.

SEDA, P.“Como era verde o Meu Vale..." Pedras, louças, vidros, cachimbos: Vestígios do mundo rural no Rio de janeiro no século XIX. [UERJGEO]20120513 Interacoes Homem. Indb. Rio De Janeiro, 2013.

SEMADS. Bacias Hidrográficas e Rios Fluminenses. Síntese Informativa Por Macrorregião Ambiental. Rio De Janeiro, 2001.

SICAR. Sistema de Integração do Cadastro Ambiental Rural. Disponível em: $\quad>$ http://www.car.gov.br/publico/municipios/downloads?sigla=RJ< Acessado em 26 de abril de 2020 
SIQUEIRA, M.N; CASTRO, S.S; FARIA, K.M.S. Geografia e ecologia da paisagem: pontos para discussão. Soc. \& Nat., Uberlândia, 2013. P.557566.

SILVA, G.A.A. Dinâmica sociais, organização política e conflitos da pesca artesanal na Foz do Rio São João (RJ). / Geraldine Augusto De Araujo E Silva, UFF/ Programa De Pós-Graduação Em Antropologia. Niterói, 2012.

SILVA, J X.Geoprocessamento e Meio Ambiente. Bertrand Brasil. Rio de Janeiro, 2011.

SILVA, R. A et al. Avaliação da cobertura florestal na paisagem de Mata Atlântica no ano de 2010, na região de Ouro Preto MG. CERNE [online]. 2015, vol.21, n.2. 2015. p.301-309. Disponível em: > https://www.scielo.br/scielo.php?script=sci abstract\&pid=S0104-

77602015000200301\&lng=pt\&tlng=pt $<$ Acessado em 26 de abril de 2020

SOS MATA ATLÂNTICA. Desmatamento da Mata Atlântica é o menor registrado desde 1985. Rio de Janeiro, 25 maio. 2018. Disponível em: $>$ https://www.sosma.org.br/projeto/atlas-da-mata-Atlântica/dados-maisrecentes/< Acessado em 26 de abril de 2020

SOUZA, C.G. Análise da fragmentação florestal da Área de Proteção Ambiental Coqueiral, Coqueiral - MG Ciênc. Florest. Vol.24, N.3, 2014. p.631-644.

SPAROVEK, G.; BARRETTO, A.; KLUG, I.; BERNDES, G. Considerações sobre o Lei de Proteção da Vegetação Nativa brasileiro. Junho, 2010.

STOUFFER, P. C., AND BORGES, S. H .Conservation recommendations for understory birds in Amazonian forest fragments and secondary areas. In R. O. Bierregaard, C. Gascon, T. E. Lovejoy, And R. Mesquita, Editors. Lessons from Amazonia: Ecology and conservation of a fragmented forest. Yale University Press, New Haven, Connecticut. 2001. P. 248-261

TABARELLI, M., SILVA \& GASCON. forest fragmentation, synergisms and the impoverishment of neotropical forests. Biodiversity \& Conservation 1. 2005. p. 1419- 1425.

TABARELLI, M; PINTO, L.P; SILVA, J.M; HIROTA, M.M; BEDÊ, L. Desafios e oportunidades para conservação da biodiversidade na Mata Atlântica brasileira. Megadiversidade .Volume 1. № 1. Julho, 2005.

TONHASCA, A. Os serviços ecológicos da Mata Atlântica. Revista Ciência Hoje, Vol. 35, N. 205. Brasil, 2004.

TOPPA, R.H et al. Caracterização dos fragmentos florestais do município de São Vicente/SP: Subsídios para conservação do Parque estadual Xixová-Japuí. XI Congresso de Ecologia do Brasil. Porto Seguro - BA, setembro 2013.

TROLL, C. A paisagem geográfica e sua investigação. Espaço e cultura, Rio de Janeiro: UERJ, NEPEC, n. 2,, jun. 1997. p. 7 
TURNER, I.M.; CORLETT, R.T. The conservation value of small isolated fragments of lowland tropical rain forest. Trends ecol. evol. 11. 1996. p.330-333.

VANZETTO, G. V.; ROSSET DE QUADROS, F.; ROVANI, I.L.; SECRETI $D E C I A N, V$. Cadastro ambiental rural e avaliação comparativa entre o antigo e atual Lei de Proteção da Vegetação Nativa Federal em um imóvel. Ciência e Natura, Vol. 39, Núm. 2. Santa Maria, 2017. p. 259-271.

VELAZQUEZ, A.; BOCCO, G. Modelling conservation alternatives with Ilwis: a case study of the Volcano Rabbit. Itc Journal, 1994.

VIANA, V. M. Biologia e manejo de fragmentos florestais naturais. In: Congresso Florestal Brasileiro, 6. Campos do Jordão, 1990.

VIANA, V.; PINHEIRO, L. A. F. V. Conservação da biodiversidade em fragmentos florestais. Série Técnica Ipef, V. 12, 32. ESALQU/USP, 1998. p.25-42.

WASSERMAN \& BARROS. Viabilidade de utilização dos recursos hídricos da bacia do Rio São João para o complexo petroquímico do Rio de Janeiro. UFF. Niteroi, 2008.

WEY, T. Package 'corrplot': visualization of a correlation matrix. 2017. Disponível em: $<$ https://cran.rproject.org/web/packages/corrplot/corrplot.pdf> Acessado em 26 de abril de 2020

WILCOX, B.A; MURPHY, D.D. Conservation Strategy: the effects of fragmentation on extinction. American Naturalist 125. 1985.p. 879-887 